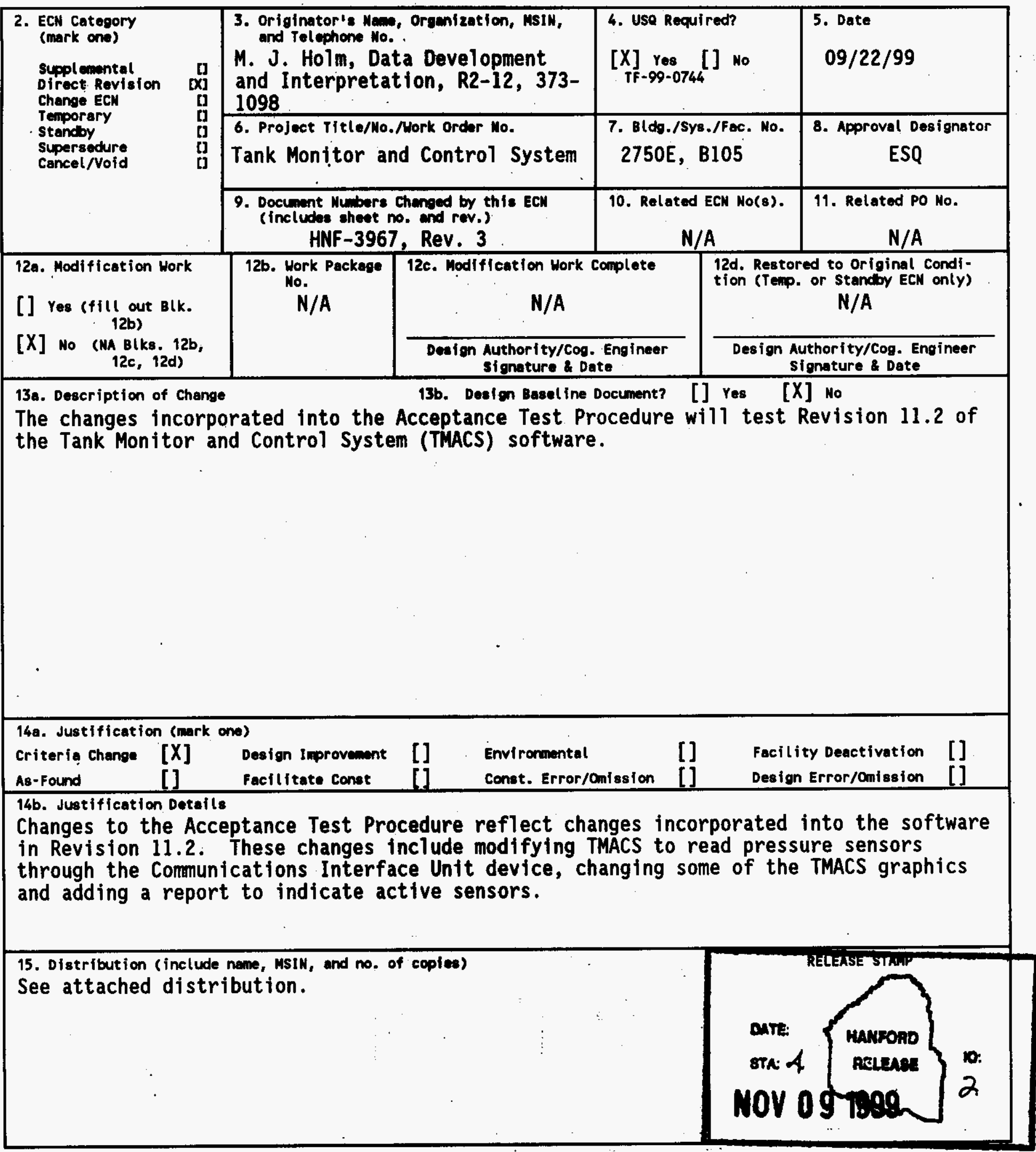




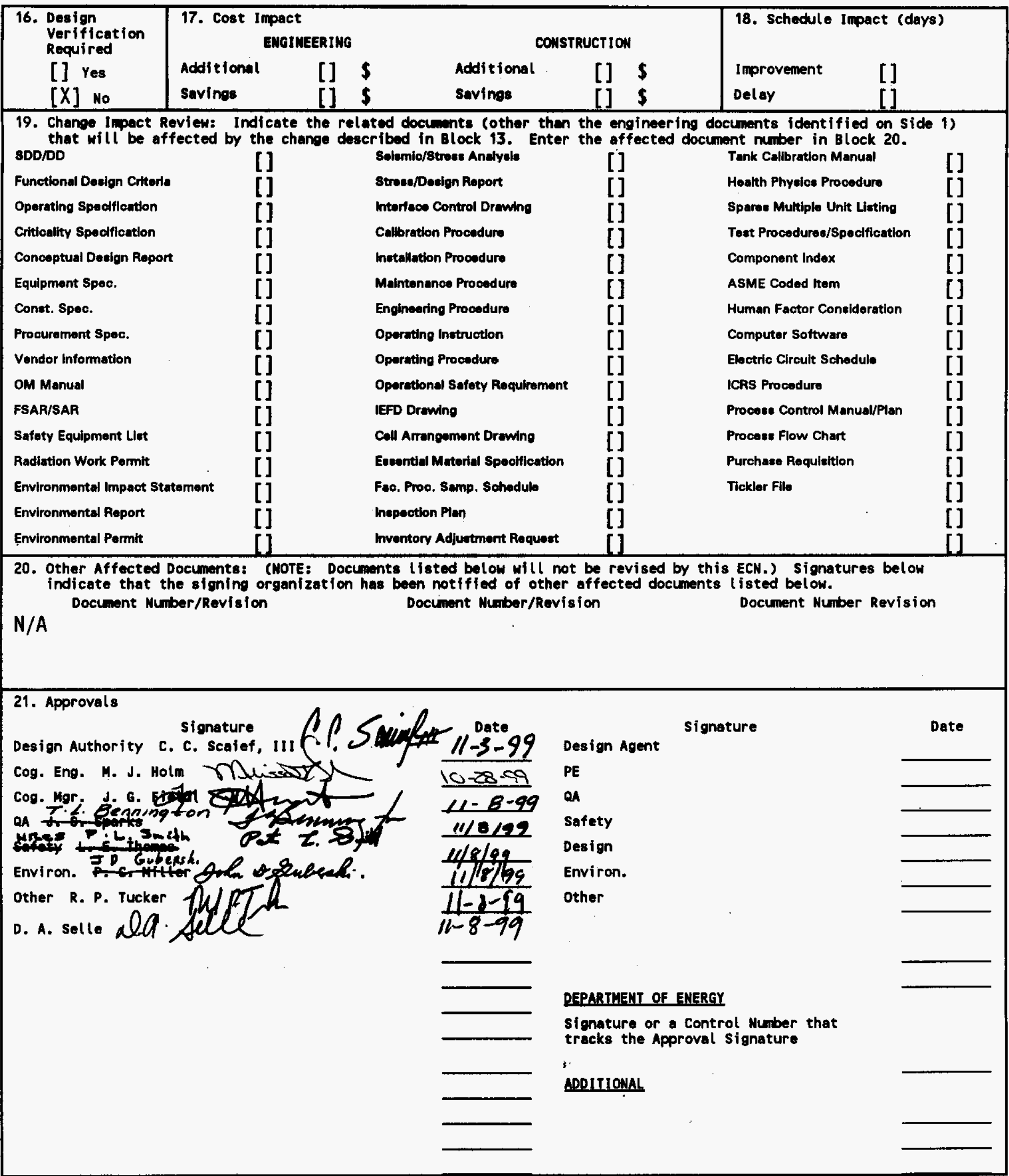




\begin{tabular}{|c|c|c|c|c|c|}
\hline \multicolumn{6}{|c|}{ DISTRIBUTION SHEET } \\
\hline \multirow{2}{*}{$\begin{array}{l}\text { To } \\
\text { Distribution }\end{array}$} & \multirow{2}{*}{\multicolumn{3}{|c|}{$\begin{array}{l}\text { From } \\
\text { Data Development and } \\
\text { Interpretation }\end{array}$}} & \multicolumn{2}{|c|}{ Page 1 of 1} \\
\hline & & & & \multicolumn{2}{|c|}{ Date $9 / 22 / 99$} \\
\hline \multicolumn{4}{|l|}{ Project Title/Work Order } & \multirow{2}{*}{\multicolumn{2}{|c|}{$\begin{array}{ll}\text { EDT No. } & \text { N/A } \\
\text { ECN No. } & 655998\end{array}$}} \\
\hline \multicolumn{4}{|c|}{$\begin{array}{l}\text { Tank Monitor and Control System (TMACS) Acceptance Test } \\
\text { Procedure (ATP) Revision } 11.2\end{array}$} & & \\
\hline Name & MSIN & $\begin{array}{l}\text { Text } \\
\text { With All } \\
\text { Attach. }\end{array}$ & Text Only & $\begin{array}{l}\text { Attach./ } \\
\text { Appendix } \\
\text { Only }\end{array}$ & $\begin{array}{l}\text { EDT/ECN } \\
\text { Only }\end{array}$ \\
\hline $\begin{array}{l}\text { D. A. Barnes } \\
\text { S. C. Cantrell } \\
\text { J. G. Field } \\
\text { M. J. Holm } \\
\text { P. C. Miller } \\
\text { D. A. Selle } \\
\text { J. S. Sparks T.L. Bennington } \\
\text { L. E. Thomas } \\
\text { R. P. Tucker } \\
\text { R. R. Wandling }\end{array}$ & $\begin{array}{l}\text { R2-12 } \\
\text { R3-47 } \\
\text { R2-12 } \\
\text { R2-12 } \\
\text { R1-51 } \\
\text { S5-03 } \\
-S 7-0755-15 \\
\text { R3-01 } \\
\text { T4-07 } \\
\text { R1-01 }\end{array}$ & $\begin{array}{l}x \\
x \\
x \\
x \\
x \\
x \\
x \\
x \\
x \\
x\end{array}$ & & & \\
\hline
\end{tabular}




\section{Tank Monitor and Control System (TMACS) Acceptance Test Procedure}

R. R. Wandling

Lockheed Martin Hanford Corporation, Richland, WA 99352

U.S. Department of Energy Contract DE-AC06-96RL13200

ECN: 655998

Org Code: 74B00

B\&R Code: EW3120071
UC: 605

Charge Code: 102608/EB00

Total Pages: 92

Key Words: Acceptance Test Procedure, ATP, TMACS, Tank Monitor and Control System, Rev. 11.2.

Abstract: This document is used to validate Revision 11.2 of the Tank Monitor and Control System (TMACS) and verify its functions as intended by design.

TRADEMARK DISCLAIMER. Reference herein to any specific commercial product, process, or service by trade nane, tradeasark, manufacturer, or otherwise, does not necessarily constitute or imply its endorsement, recominendation, or favoring by the United states Government or any agency thereof or its contractors or subcontractors.

Printed in the United states of America. To obtain coples of this docunent, contact: Document Control Services, P.0. BOX 950, Hafletop H6-08, Richland UA 99352, Phone (509) 372-2420;

Fax (509) 376-4989.
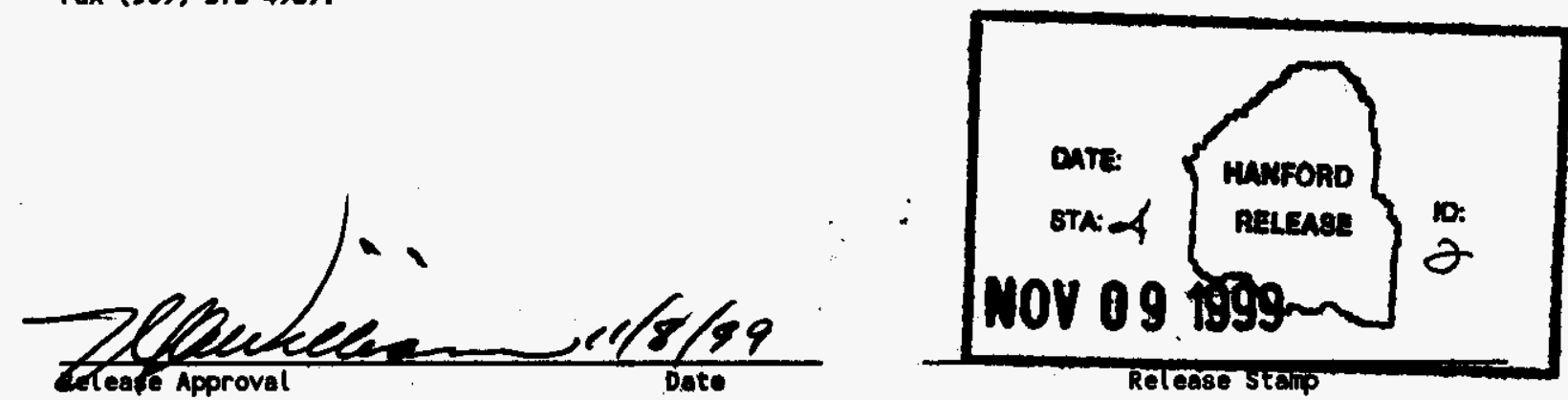

\section{Approved for Public Release}




\section{RECORD OF REVISION}

(1) Document Number

HNF-3967, Rev. 4

Page 1

(2) Title

Tank Monitor and Control System (TMACS) Acceptance Test Procedure for Revision 11.2. CHAMYE COITROL RECOAD

(3) Revision (4) Description of Change - Replace, Add, and Delete Pages

(7) HNF-3538 (EDT 625999)

Authorized for Release

(5) Cor. Engr. (6) Cog. Mgr. Date

0 (7)

M. J. Holm

N. W. Kirch

1

Complete revision per ECN 653556 .

M. J. Holm

N. W. Kirch

2

Complete revision per ECN 654685 .

M. J. Holm

K. M. Hall

3

Complete revision per ECN 654987.

M. J. Holm

${ }_{4}$ RS

Complete revision per ECN 655998.

M. S. Holm

K. M. Hall
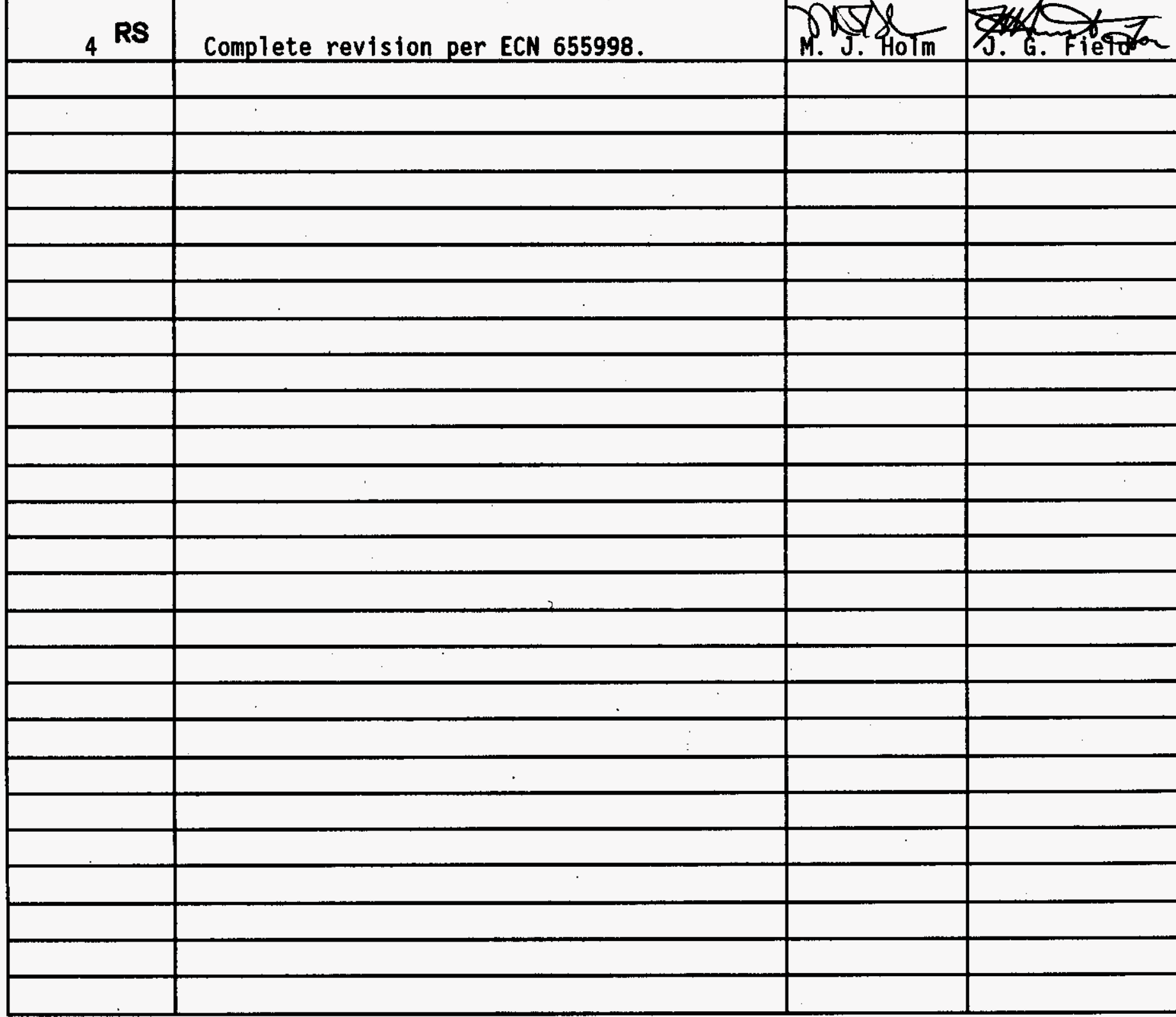
HNF-3967, Rev. 4

\title{
TANK MONITOR AND CONTROL SYSTEM (TMACS) ACCEPTANCE TEST PROCEDURE
}

\author{
Prepared By \\ Ronald R. Wandling \\ Lockheed Martin Services Inc.
}

For

Lockheed Martin Hanford

For

US Department of Energy

Richland Operations Office

Richland, Washington 


\section{TABLE OF CONTENTS}

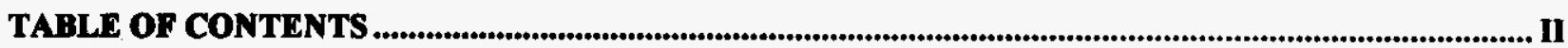

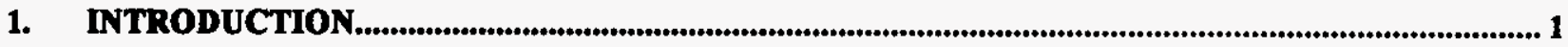

1.1 PURPOSE

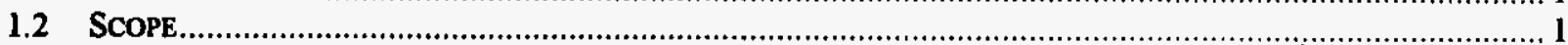

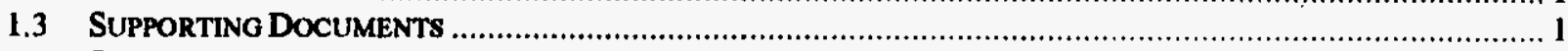

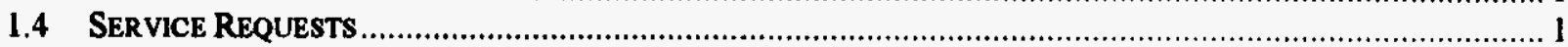

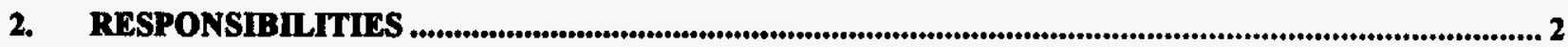

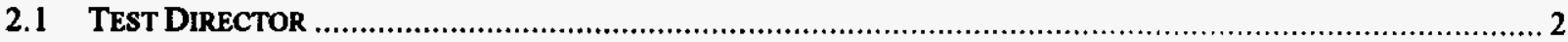

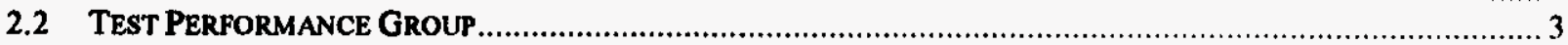

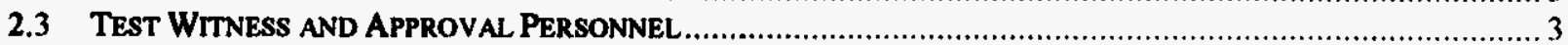

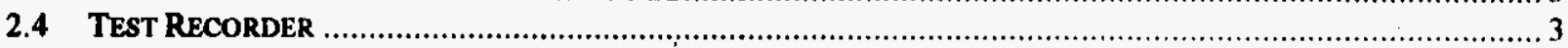

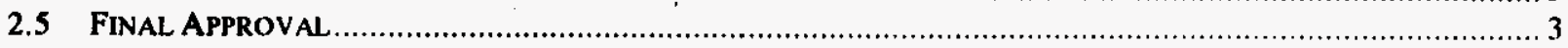

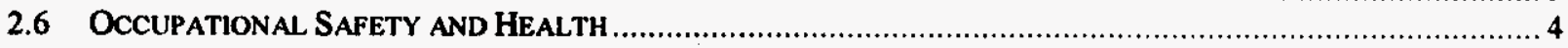

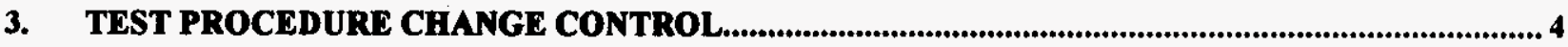

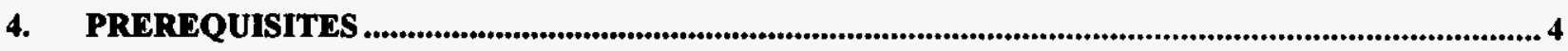

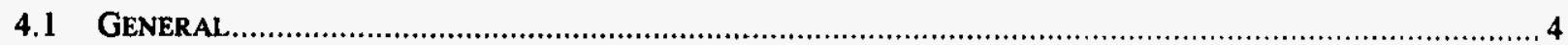

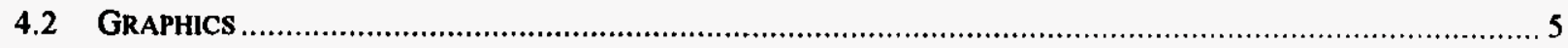

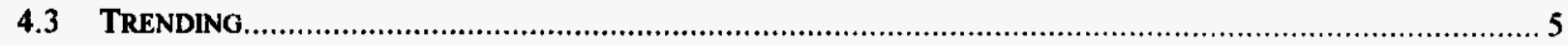

4.4 REPORTS

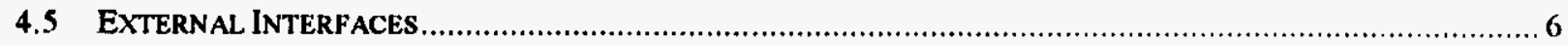

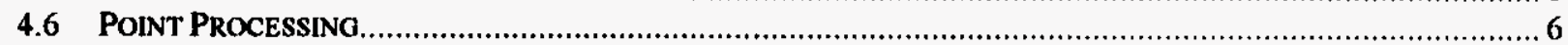

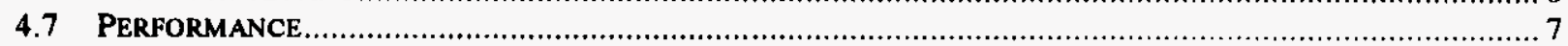

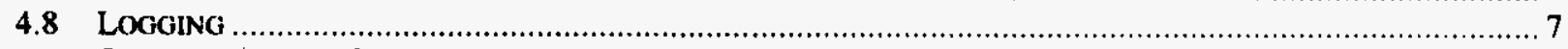

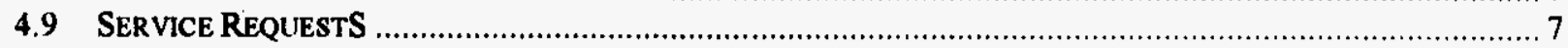

5. ACCEPTANCE CRITERIA

5.1 GENERAL

5.2 GRAPHICS

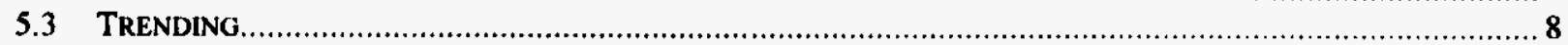

5.4 REPORTS

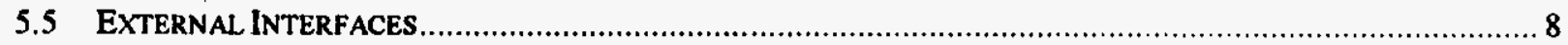

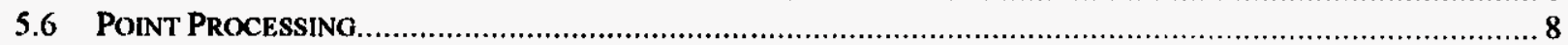

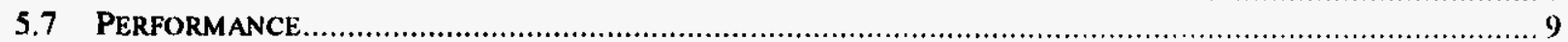

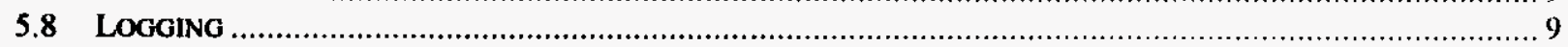

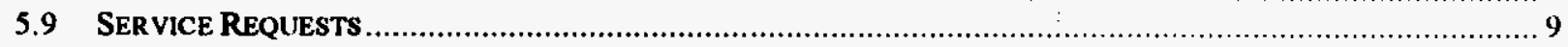

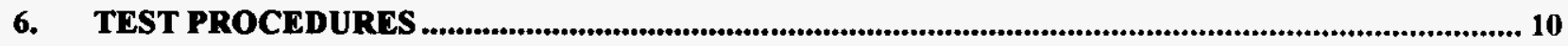

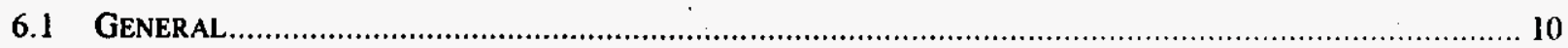

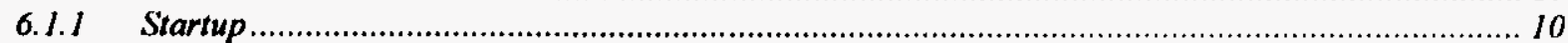

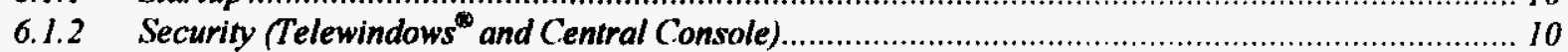

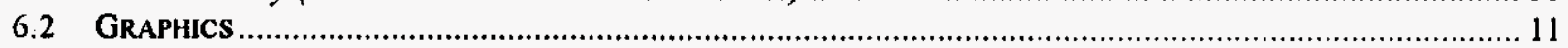

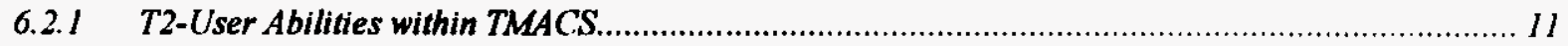

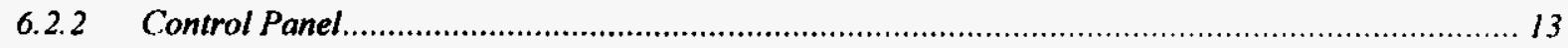

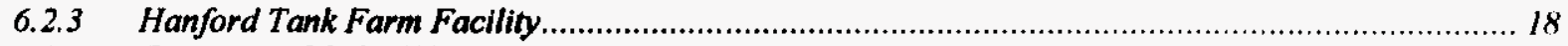

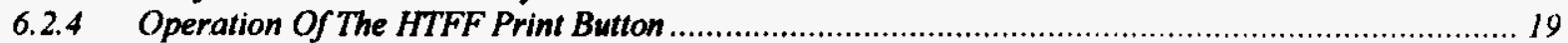

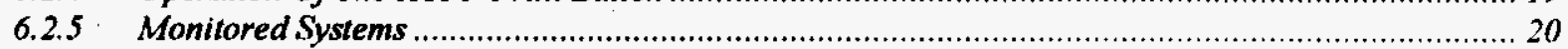

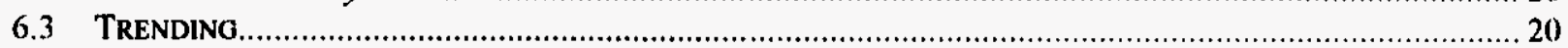

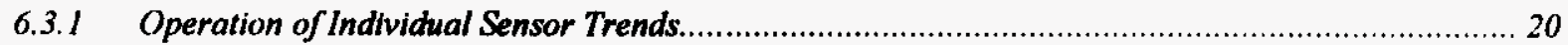




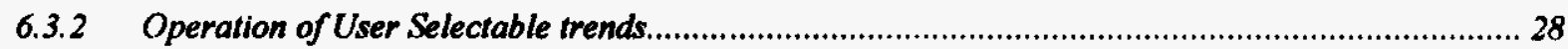

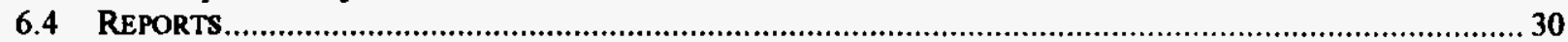

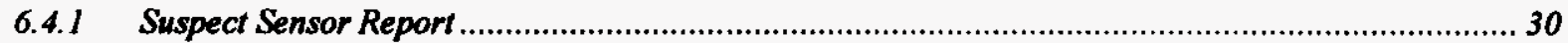

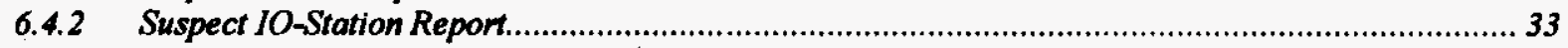

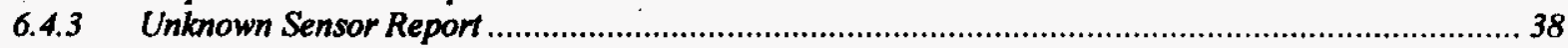

6.4.4 ENRAF Non-Operating Mode Report............................................................................... 40

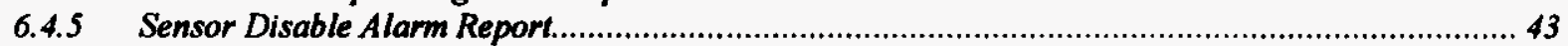

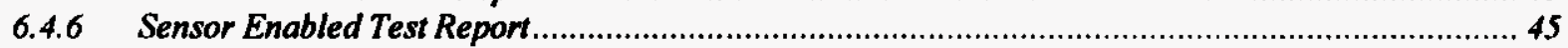

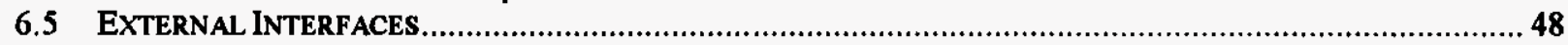

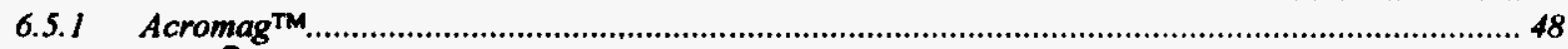

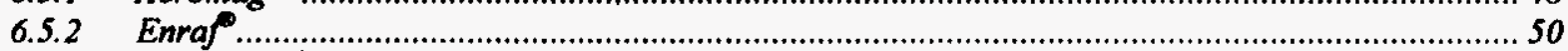

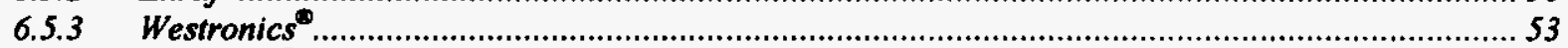

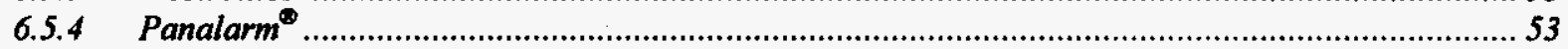

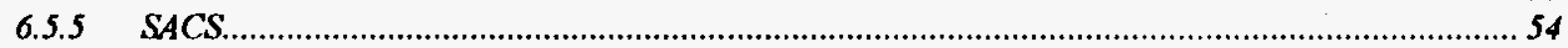

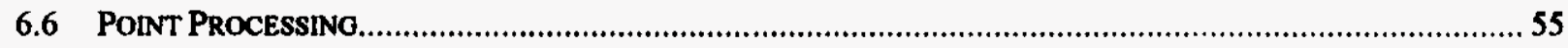

6.6.I Continuous Sensor (Non Rate of Change) Automated Functional Test ....................................... 55

6.6.2 Continuous Sensor (Rate of Change) Automated Functional Test ............................................... 56

6.6.3 Discrete Sensor Automated Functional Test ................................................................................ 56

6.6.4 Operation of MOST RECENT ALARM and CURRENT ALARMS ................................................ 57

6.6.5 Operation of Sensor Delta Band and Alarm Deadband .........................................................5

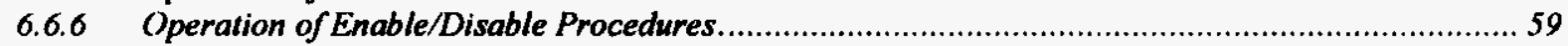

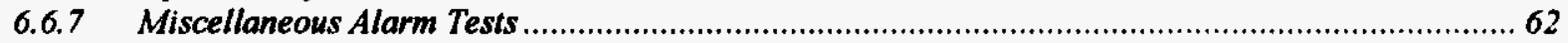

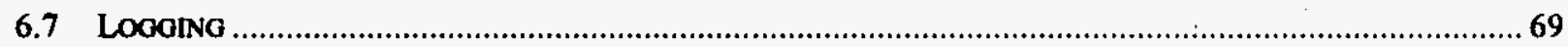

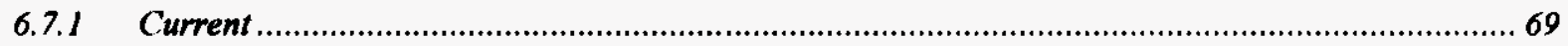

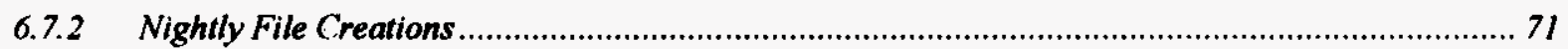

6.8 PERFORMACE

6.8.1 CPU Use Vs Number of Continuous Points/Sec Performance Test ................................................. 72

6.8.2 CPU Use Vs Number of Discrete Points/Sec Performance Test ................................................... 73

6.8.3 CPU Use Vs Pt-Processing Function for Continuous Points Performance Test................................ 73

6.8.4 CPU Use Vs Point-Processing Function for Discrete Points Performance Test................................ 74

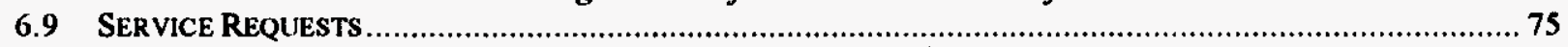

6.9.1 SR 103--Make the GSI Data Service Priority Lower Than The Processing Rule Priority …….......... 75

6.9.2 SR 132 - Add Individual Trend Graphs For Discrete Sensors.................................................. 75

6.9.3 SR 166 - Modify TMACS To Display the K-Basin Communications Alarm As Red........................ 76

6.9.4 SR 403 - Modify TMACS To Generate A Sensor Limits List .................................................. 76

6.9.5 SR 434-Modify TMACS To Read Pressure Sensors through ENRAF CIU device. .......................... 77

6.9.6 SR 752 - Modify ENRAF Driver To Properly Handle "!" Commands ......................................... 77

6.9.7 SR 856-Devise Method To Notify The Operator When An ENRAF Level Gauge Has A Status Other

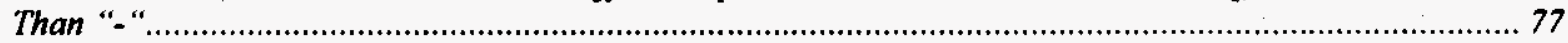

6.9.8 SR 857 - Correct Unknown Sensor Report To Display Only Sensors Associated With Tanks.......... 77

6.9.9 SR 858-Modify The Suspect Sensor 1O.Station Report To Not Display. Stations With A Polling

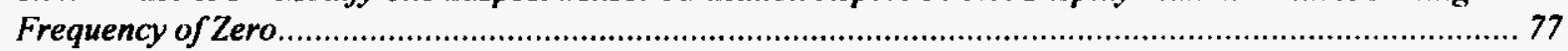

6.9.10 SR 860 - Correct Problem of Old Print Workspace Being Displayed For Multiple Sensor Trends... 77

6.9.11 SR 862-Correct Problem Where Sensor With Alarm Processing Turned Off Does Not Restore To

Correct Color When Communications Are Re-Established ..................................................................... 78

6.9.12 SR 865 - Set Polling Frequency Of Double Shell Tanks To 10 Minutes Or Less............................. 78

6.9.13 SR 867 - Add Ability To Place A Sensor Into Test Mode............................................................... 79

6.9.14 SR 869 - Configure Enraf Of Tanks BY102 and S110................................................................... 79

6.9.15 SR 871 - Change Gauge Addresses for ENRAF Level Devices in Tanks AP105-AP108................. 79

6.9.16 SR 873 - Create Report That Displays Active Sensors With Alarm Processing Disabled................. 79

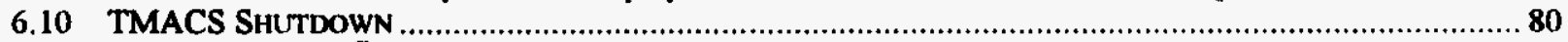

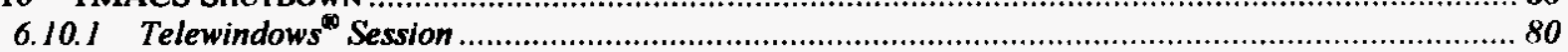

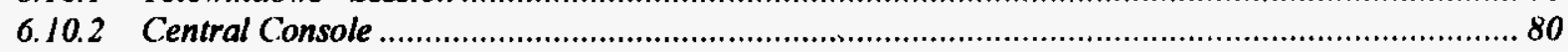

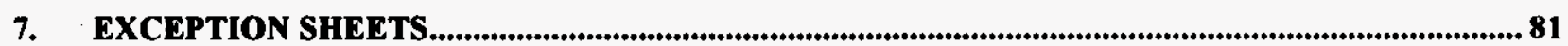


HNF-3967, Rev. 4

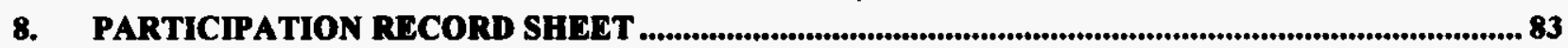

9. ACCEPTANCE RECORD SHEET $\ldots$ 


\section{INTRODUCTION}

\subsection{PURPOSE}

The purpose of this document is to describe tests performed to validate Revision 11.2 of the TMACS Monitor and Control System (TMACS) and verify that the software functions as intended by design.

\subsection{SCOPE}

This document is intended to test the software portion of TMACS. The tests will be performed on the development system. The software to be tested is the TMACS knowledge bases (KB) and the I/O driver/services. The development system will not be talking to field equipment; instead, the field equipment is simulated using emulators or multiplexers in the lab.

\subsection{SUPPORTING DOCUMENTS}

- "Double-Shell Underground Waste Storage Tanks - Riser Survey," SD-RE-TI-093, Rev. 1, December 2, 1986.

- "Riser Configuration Document for Single-Shell Waste Tanks", SD-RE-TI-053, Rev. 8, August 22, 1991.

- “TMACS I/O Termination Point Listing”, WHC-SD-WM-TI-594, Current Revision.

- “TMACS Data File Formats, Release 11.0," Lockheed Martin Services, Inc. External Letter, RGG-SDI-99-001.

\subsection{SERVICE REQUESTS}

The following are the services requests incorporated into the TMACS software for this release.

\begin{tabular}{|l|l|}
\hline SR II & \multicolumn{1}{|c|}{ ABbreviated Description } \\
\hline 103 & $\begin{array}{l}\text { Make the GSI Data Service Priority lower than the Processing Rule } \\
\text { Priority }\end{array}$ \\
\hline 132 & Add individual trend graphs for discrete sensors \\
\hline 166 & $\begin{array}{l}\text { Modify TMACS to display the color red for a K-Basin } \\
\text { Communications Alarm }\end{array}$ \\
\hline 403 & Modify TMACS to display the sensor limits for a sensor. \\
\hline 434 & $\begin{array}{l}\text { Modify TMACS To Read Pressure Sensors through ENRAF CIU } \\
\text { device }\end{array}$ \\
\hline
\end{tabular}


HNF-3967, Rev. 4

\begin{tabular}{|l|l|}
\hline SR & \\
\hline 752 & Modify The ENARF Driver To Properly Handle The "!" Commands \\
\hline 856 & $\begin{array}{l}\text { Devise A Method To Notify The Operator When An ENRAF Level } \\
\text { Gauge Has A Status Other Than “-“ }\end{array}$ \\
\hline 857 & $\begin{array}{l}\text { Correct Unknown Sensor Report To Display Only Sensors Associated } \\
\text { With Tanks. }\end{array}$ \\
\hline 858 & $\begin{array}{l}\text { Modify The Suspect IO Station Report To Not Display Station With A } \\
\text { Polling Frequency Of Zero. }\end{array}$ \\
\hline 860 & $\begin{array}{l}\text { Correct Problem Of Old Print Screen Button Being Displayed For } \\
\text { Multiple Sensor Trends }\end{array}$ \\
\hline 862 & $\begin{array}{l}\text { Correct Problem Where Sensor With Alarm Processing Turn Off Do } \\
\text { Not Restore To Correct Color When Communications Are Re- } \\
\text { Established. }\end{array}$ \\
\hline 865 & Set Polling Frequency Of Double Shell Tanks To 10 Minutes Or Less. \\
\hline 867 & $\begin{array}{l}\text { Add Ability To Place A Sensor Into Test Mode. } \\
\text { Configure TMACS To Have ENRAF Level Gauges For Tanks BY102 } \\
\text { And S110 }\end{array}$ \\
\hline 871 & $\begin{array}{l}\text { Change Gauge Addresses for ENRAF Level Devices in Tanks AP105- } \\
\text { AP108 }\end{array}$ \\
\hline 873 & $\begin{array}{l}\text { Create Report That Displays Active Sensors With Alarm Processing } \\
\text { Disabled }\end{array}$ \\
\hline
\end{tabular}

\section{RESPONSIBILITIES}

Each organization participating in the conduct of this ATP will designate personnel to assume the responsibilities and duties as defined herein for their respective roles. Prior to the performance of this ATP these designees shall sign the ATP Participation Sheet.

\subsection{TEST DIRECTOR}

- Provides concurrence that the ATP may commence.

- Act as liaison between the test performance group and the test witnesses.

- Shall perform the test as described in this document.

- Record exceptions and test steps that are not performed on the ATP Exception Record sheets. Add additional Exception Record sheets as needed.

- Shall obtain final approval signatures and distribute copies of the ATP. 
HNF-3967, Rev. 4

- Stop any test that, in the judgment of the Test Director, may cause damage to the system until the test procedure has been revised.

\subsection{TEST PERFORMANCE GROUP}

- Shall provide qualified personnel, tools and equipment required to perform test.

\subsection{TEST WITNESS AND APPROVAL PERSONNEL}

- Shall observe the testing and data recording to verify that their group's requirements are met.

If any representative of the witness and approval personnel objects to the results obtained during the acceptance test, he shall notify the Test Director. Any such notice, if not resolved directly to the representative's satisfaction, shall be recorded as an exception.

\subsection{TEST RECORDER}

- Get signatures on the Recorder's copy of the Acceptance Test Procedure Participation sheet prior to testing.

- Observe tests and record test data (if any).

- Initial every test step on the Recorder's copy as it is completed, next to the step number or table, when provided.

- Record exceptions and test steps, which are not performed on the Exception Sheet.

- Notify the Test Director of an exception at time the exception is made.

- Transfer Recorder's copy of the completed ATP with the final test results and signatures to the Test Director for Final Approval signatures and disposition.

\subsection{FINAL APPROVAL}

- Approval personnel shall indicate, by their signature on the ATP Acceptance Record Sheet that the ATP result's are accepted. Any questions or objections shall be referred to the Test Director for resolution.

If the approval personnel find an exception to the test that is of sufficiently small magnitude, a test approval may be given. In this case, a list of such exceptions shall be entered in the exception page as "Test Approved with Exceptions," signed and dated. This signature shall 
indicate that the exceptions are of such a nature that a rerun of the ATP is not necessary to demonstrate that the exceptions have been adequately resolved.

\subsection{OCCUPATIONAL SAFETY AND HEALTH}

- Individuals shall perform their assigned tasks in a safe manner to protect themselves and others from undue hazards and to prevent damage to property and environment.

\section{TEST PROCEDURE CHANGE CONTROL}

Acceptance testing shall be conducted in accordance with the steps and requirements specified in this procedure. In the event minor changes are required to successfully complete the Acceptance Test Procedure the change shall be noted as an exception and testing continued, only if the change will not effect the test acceptance criteria. The exception shall be incorporated into this document in accordance with HNF-PRO-440, "Engineering Document Change Control, Requirements."

\section{PREREQUISITES}

This section describes the prerequisites required to perform this ATP. The section contains general prerequisites that apply to this test procedure as well as specific prerequisites for individual test procedures.

\subsection{GENERAL}

The following are the prerequisites for running any of the test sections described in this procedure.

1. The Test Director should bring up G2' ${ }^{1}$ with the TMACS_Main.KB and log in using the mode "t2-user" prior to running the formal test.

2. The Test Director should bring up a $G 2^{\infty}$ telewindows 2 session and log in using the mode "t2-user" prior to running the formal test.

3. The Test Director should verify that following bridges/services are started as services on WindowsNTTM.

\footnotetext{
${ }^{1} \mathrm{G} 2$ is a registered trademark of the Gensym Corporation.

${ }^{2}$ Telewindows is a registered trademark of the Gensym Corporation.
} 


\begin{tabular}{|c|c|c|}
\hline Common Name & Executable & Service Name \\
\hline Acromag $^{3}$ I/O driver & Acromag_driver.exe & $\begin{array}{l}\text { AcromagDriver } 22200 \\
\text { AcromagDriver } 22201 \\
\text { AcromagDriver } 22202 \\
\text { AcromagDriver } 22203 \\
\text { AcromagDriver } 22204 \\
\text { AcromagDriver } 22205\end{array}$ \\
\hline Alarm Printer driver & Tmacs_printer_driver.exe & TMACSPrtDriver 22300 \\
\hline Enraf ${ }^{9} \mathrm{I} / \mathrm{O}$ driver & Enraf_driver.exe & EnrafDriver 22206 \\
\hline Panalarm ${ }^{4} \mathrm{I} / \mathrm{O}$ driver & Panalm_driver.exe & PanalmDriver 22207 \\
\hline Westronic $^{5} \mathrm{l} / \mathrm{O}$ driver & Westronic.driver & WestronicDriver 22212 \\
\hline G2 $^{\Phi}$ ODBC Bridge & & $\mathrm{G}^{\infty}$ ODBC Bridge \\
\hline
\end{tabular}

4. The Test Director shall have available the latest version of the following reference materials:

- “TMACS I/O Termination Point Listing”, (WHC-SD-WM-TI-594, current revision), document written by Instrument \& Control (I\&C). The electronic version is available at IVAP014\TMACS.

- "Riser Configuration Document for Single-Shell Waste Tanks", (SD-RE-TI-053, Rev. 8).

- Double-Shell Underground Waste Storage Tanks - Riser Survey", (SD-RE-TI-093, Rev. 1).

5. The serial multiplexers or emulators for the Acromag ${ }^{\mathrm{TM}}$, Enraf $^{\infty}$, Panalarm, ${ }^{\infty}$ and Westronic $^{\infty}$ devices are available. At least one serial multiplexer (or emulator) is attached to the test computer and that the appropriate driver can function through the appropriate serial port.

\subsection{GRAPHICS}

No additional prerequisites are needed.

\subsection{TRENDING}

To give a proper display of trending it is strongly advised that 1 or more days of history files be copied from production to the system to be tested (give enough time for the files to be processed) and run into the development TMACS.

\footnotetext{
${ }^{3}$ Acromag is a trademark of Acromag Incorporated, Wixom, Michigan.

${ }^{4}$ Panalarm is a registered trademark of Ametek, Inc.

${ }^{5}$ Westronics is a registered trademark of Westronics, Inc.
} 


\subsection{REPORTS}

No additional prerequisites are needed.

\subsection{EXTERNAL INTERFACES}

No additional prerequisites are needed.

\subsection{POINT PROCESSING}

1. This test requires the system to be in a state in which no other alarm activity is generated externally. The Test Director may need to disable the collection of sensor readings from the lab equipment and clear alarm messages generated by the system start up.

2. The individual Test Cases are built using tank "Test-20l", which contains one discrete and one continuous sensor. The current values for these sensors are entered programmatically; the tests assume that the following parameters have been set for sensor Continuous-200001. Verify that the sensor has the parameters in Table 1.

Table 1. Parameters for Sensor Continuous-200001

\begin{tabular}{|l|l|}
\hline \multicolumn{1}{|c|}{ Parameter } & \multicolumn{1}{c|}{ Value } \\
\hline High Instrument Limit & 22 \\
\hline High Alarm Limit & 15 \\
\hline Low Alarm Limit & 10 \\
\hline Low Instrument Limit & 4 \\
\hline Delta Band & 0.0 \\
\hline Alarm Deadband & 0.9 \\
\hline Rate of Change & 1.2 \\
\hline ROC Limit & 2.2 \\
\hline
\end{tabular}

3. Verify that the discrete sensor, Discrete-200001, has the values for the parameters listed in Table 2.

Table 2. Parameters for Sensor Discrete-200001

\begin{tabular}{|l|l|l|}
\hline State $0=$ Normal & Color $=$ Green & Annotation $=$ OPEN \\
\hline State $1=$ Alarm & Color $=$ Yellow & Annotation $=$ CLOSING \\
\hline State $2=$ Alarm & Color $=$ Red & Annotation $=$ CLOSED \\
\hline State 3 = Normal & Color $=$ Green & Annotation = OPENING \\
\hline High Instrument Limit $>3$ & Low Instrument Limit $<0$ \\
\hline
\end{tabular}

4. To set up the tests in this section the Test Director must: 
- Load the testing knowledge base (KB)

- Bring up the Point Processing Functional Tests workspace

- Enter the test document revision number (i.e. 11.0).

5. The functional tests will be run individually in the test cases. The tester must be logged in to $\mathrm{G}^{\circ}$ in "administrator" mode.

\subsection{PERFORMANCE}

1. This purpose of this test section is to bench mark the production software using the development computer. The tests will be performed on the computer with the minimum TMACS processes running. The development computer will be running the following software during the test:

- WindowsNTTM and related system programs that will be running in production

- $\mathrm{G} 2{ }^{\star}$ with the production TMACS knowledge bases. There should be no data recovery operations in place during the test!!!

- All driver services that would be running in production. None of these services should be receiving data from the field, lab, or emulators.

2. To set up the tests in this section the Test Director must:

- Acknowledge all the alarms from the startup process

- Load the testing knowledge base (KB)

- Hide all the workspaces until only the $G 2^{\infty}$ background bricks appear

- Bring up the Point Processing Performance Tests workspace

- Enter the test document revision number (i.e. 11.0).

\subsection{LOGGING}

The Test Director may want to start and have the TMACS system running overnight to create the automated data files for this test.

\subsection{SERVICE REQUESTS}

\section{ACCEPTANCE CRITERIA}

\subsection{GENERAL}

The system shall provide multiple security levels that are password protected. 


\subsection{GRAPHICS}

The acceptance criteria for graphics is:

- Provide real-time display of numeric values of sensors

- Communicate with a minimum of 2 graphics CRTs

- Provide "PRINT" facility for graphic window displays.

\subsection{TRENDING}

The acceptance criteria trending is:

- Provide real-time trend graphs, with the following selected time intervals: 1 hour, 7 days.

\subsection{REPORTS}

The acceptance criteria is:

- Provide a list of active sensors that have not recorded a reading for the current day.

- Provide a list of sensors that are recording readings that are unreliable. (Status unknown)

- Provide a list of io-stations that are not reporting.

\subsection{EXTERNAL INTERFACES}

The system shall be capable of providing sensor information to the Surveillance Analysis Computer System (SACS) for sensors configured in both SACS and TMACS.

The acceptance criteria sensor conversion is:

- The system shall convert the data read by the field equipment in a user readable format.

\subsection{POINT PROCESSING}

The acceptance criteria trending is:

- Provide real-time alarming on high and low level for any analog point

- Provide alarm deadband filtering for analog points

- Display the following alarm colors: red for highest priority, requiring immediate action; yellow for an abnormal condition requiring attention but not an immediate hazard; white for status indication; green for normal condition 
- Provide alarm summary display with date, time, tag, description, alarm status with color-coding (green for normal). Remove message from display upon acknowledgement and reset/return to normal

- Display tanks and sensors with unacknowledged alarms as blinking

- Provide operator alarm acknowledgement. Acknowledgement action shall cease blinking of alarmed item

- Provide logging of alarms, return to normal, and alarm acknowledgements, to printer and to disk

- Provide alarming when error codes are returned from data acquisition system.

\subsection{PERFORMANCE}

The acceptance criteria trending is:

- The TMACS G2 $2^{\star}$ program shall process input from 50 points per second while using less than $80 \%$ of the CPU time.

\subsection{LOGGING}

The acceptance criteria trending is:

- The system shall have the capability to log any sensor value

- A sensor logging shall include the time stamp and the sensor's value.

\subsection{SERVICE REQUESTS}

The acceptance criteria for the service request (SR) are contained in the description of the SR. The test director will have available a copy of the service request for viewing. 


\section{TEST PROCEDURES}

\subsection{GENERAL}

\subsubsection{Startup}

Note: The Test Director prior to witness testing may have completed this test.

\begin{tabular}{|l|l|l|l|}
\hline Step & \multicolumn{1}{|c|}{ Perform } & \multicolumn{1}{c|}{ Verify } & Initial \\
\hline 1. & Start TMACS & $\begin{array}{l}\text { Verify the TMACS starts up (approximately ten } \\
\text { minutes) and verify the following: }\end{array}$ & \\
$\begin{array}{l}\text { On the TMACS screen, } \\
\text { type Control-Y }\end{array}$ & $\begin{array}{l}\text { A message is displayed indicating what days } \\
\text { worth of data is being recovered. }\end{array}$ & $\begin{array}{l}\text { A status bar is displayed indicating what } \\
\text { percentage of the days readings have been } \\
\text { read into memory. }\end{array}$ & \\
t2-user & $\begin{array}{l}\text { Edit the 'Password' to be } \\
\text { the password for t2-user } \\
\text { Edit the 'G2 } \\
\text { be t2-user }\end{array}$ & & \\
\hline
\end{tabular}

\subsubsection{Security (Telewindows ${ }^{(*)}$ and Central Console)}

\begin{tabular}{|c|c|c|c|}
\hline Step & Action & Verify & Initial \\
\hline 1. & $\begin{array}{l}\text { On the TMACS screen, } \\
\text { type Control-Y. }\end{array}$ & $\begin{array}{l}\text { Verify that the user mode selection workspace } \\
\text { appears on the screen with " } 2 \text {-user" in the name } \\
\text { field. }\end{array}$ & \\
\hline 2. & $\begin{array}{l}\text { Edit the 'G2 }{ }^{9} \text { user mode' to } \\
\text { be something other than } \\
\text { t2-user or shut down. } \\
\text { (i.e. "administrator".) } \\
\text { Click on the END button in } \\
\text { the user mode selection } \\
\text { workspace. }\end{array}$ & $\begin{array}{l}\text { Verify that TMACS does not enter selected } \\
\text { mode. }\end{array}$ & \\
\hline 3. & $\begin{array}{l}\text { Edit the 'G2 }{ }^{\circ} \text { user mode' to } \\
\text { be "t } 2 \text {-user" and click on } \\
\text { the END button. }\end{array}$ & $\begin{array}{l}\text { Verify that the user mode selection workspace } \\
\text { disappears from the screen (indicating a } \\
\text { successful login). }\end{array}$ & \\
\hline
\end{tabular}




\subsection{GRAPHICS}

This section is performed after the system has been started and the clock is functional. This test should be performed on both the main console and Telewindows ${ }^{\star}$.

\subsubsection{T2-User Abilities within TMACS}

\subsubsection{Central Console or Telewindows}

\begin{tabular}{|c|c|c|c|}
\hline \multirow[t]{2}{*}{ Step } & \multirow[t]{2}{*}{ Action } & \multirow[b]{2}{*}{ 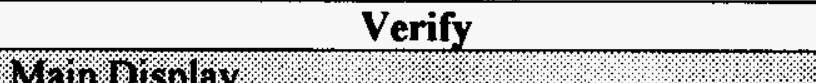 } & \multirow[t]{2}{*}{ Initial } \\
\hline & & & \\
\hline 1. & $\begin{array}{l}\text { Click on the Show Main } \\
\text { Display button on the } \\
\text { Control Panel. }\end{array}$ & $\begin{array}{l}\text { Verify that the following workspaces appear on } \\
\text { the screen: } \\
\text { - Control Panel. } \\
\text { - Monitored Systems } \\
\text { - Most Recent Alarm. } \\
\text { N Hanford Tank Farm Facilities } \\
\text { Note: Working window (may appear if Data } \\
\text { Recovery is still running) }\end{array}$ & \\
\hline 2. & $\begin{array}{l}\text { Attempt to move several } \\
\text { objects chosen at random } \\
\text { on the workspace by doing } \\
\text { a click-and-drag. }\end{array}$ & Verify that they do not move. & \\
\hline 3. & $\begin{array}{l}\text { Click anywhere in the } \\
\text { empty space on each } \\
\text { workspace. }\end{array}$ & Verify that no menus appear. & \\
\hline \multicolumn{2}{|c|}{ म" } & Tank Status Display & \\
\hline 4. & $\begin{array}{l}\text { Click on the tank icon for } \\
\text { any active tank. }\end{array}$ & Verify that the Tank Status workspace appears. & \\
\hline 5. & $\begin{array}{l}\text { Click on the Shrink } \\
\text { Window button on the } \\
\text { Tank Status workspace. }\end{array}$ & Verify that the workspace size is reduced. & \\
\hline 6. & $\begin{array}{l}\text { Move by dragging the } \\
\text { Tank Status Window. }\end{array}$ & $\begin{array}{l}\text { Verify that the workspace moves; verify that no } \\
\text { part of the workspace can be moved off-screen. }\end{array}$ & \\
\hline 7. & $\begin{array}{l}\text { Attempt to move several } \\
\text { objects chosen at random } \\
\text { on the Tank Status } \\
\text { workspace by doing a } \\
\text { click-and-drag. }\end{array}$ & Verify that none of the objects move. & \\
\hline \multicolumn{4}{|c|}{$\begin{array}{lll} & \text { Sersor Trend Display } \\
\end{array}$} \\
\hline 8. & $\begin{array}{l}\text { Click on icon for any } \\
\text { sensor. } \\
\text { Note: Reading and Label } \\
\text { are not part of sensor icon. }\end{array}$ & $\begin{array}{l}\text { Verify that the trend workspace for that sensor } \\
\text { appears. }\end{array}$ & \\
\hline
\end{tabular}


HNF-3967, Rev. 4

\begin{tabular}{|c|c|c|c|}
\hline Step & Action & Verify & Initial \\
\hline 9. & $\begin{array}{l}\text { Click at random at several } \\
\text { places on the trend } \\
\text { workspace. }\end{array}$ & Verify that no menu appears. & \\
\hline 10. & $\begin{array}{l}\text { Attempt to move several } \\
\text { objects chosen at random } \\
\text { on the trend workspace. }\end{array}$ & Verify that none move. & \\
\hline 11. & $\begin{array}{l}\text { Click on the Hide } \\
\text { Workspace button on the } \\
\text { trend workspace. }\end{array}$ & Verify that the workspace disappears. & \\
\hline \multicolumn{2}{|c|}{ 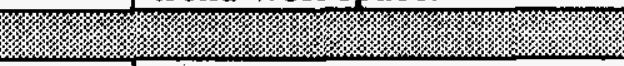 } & \multirow{2}{*}{\multicolumn{2}{|c|}{$\begin{array}{l}\text { Verify that doing so brings the Control Panel to } \\
\text { the top. }\end{array}$}} \\
\hline 12. & $\begin{array}{l}\text { Move Tank Status over a } \\
\text { portion of the Control } \\
\text { Panel workspace. } \\
\text { Click on the background of } \\
\text { the Control Panel } \\
\text { workspace. }\end{array}$ & & \\
\hline 13. & $\begin{array}{l}\text { Click on the Hide Window } \\
\text { button on the Tank Status } \\
\text { workspace. }\end{array}$ & Verify that the workspace disappears. & \\
\hline & 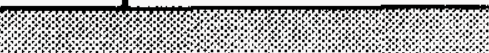 & \multicolumn{2}{|l|}{ Monitored Syrtems } \\
\hline 14. & $\begin{array}{l}\text { Click on any button on the } \\
\text { MONITORED SYSTEMS } \\
\text { workspace. }\end{array}$ & $\begin{array}{l}\text { Verify that the monitored system chosen } \\
\text { workspace appears. }\end{array}$ & \\
\hline 15. & $\begin{array}{l}\text { Click at random at several } \\
\text { places on the workspace. }\end{array}$ & Verify that no menu appears. & \\
\hline 16. & $\begin{array}{l}\text { Attempt to move several } \\
\text { objects chosen at random } \\
\text { on the workspace. }\end{array}$ & Verify that none move. & \\
\hline 17. & $\begin{array}{l}\text { Click on the Hide Window } \\
\text { button on the workspace. }\end{array}$ & Verify that the workspace disappears. & \\
\hline
\end{tabular}

\subsubsection{Central Console Only}

\begin{tabular}{|c|c|c|c|}
\hline Step & Action & Verify & Initial \\
\hline 1. & $\begin{array}{l}\text { Click on the Show Main } \\
\text { Display button on the } \\
\text { Control Panel. }\end{array}$ & $\begin{array}{l}\text { Verify that the following workspaces appear on } \\
\text { the screen: } \\
\text { - Control Panel. } \\
\text { - Monitored Systems } \\
\text { - Most Recent Alarm. } \\
\text { - Hanford Tank Farm Facilities } \\
\text { Note: Working window may appear if Data } \\
\text { Recovery is still running. }\end{array}$ & \\
\hline 2. & $\begin{array}{l}\text { Click on the tank icon for } \\
\text { any active tank. }\end{array}$ & Verify that the Tank Status workspace appears. & \\
\hline
\end{tabular}


HNF-3967, Rev. 4

\begin{tabular}{|c|c|c|c|}
\hline Step & Action & Verify & Initial \\
\hline & পি. & \multicolumn{2}{|l|}{ 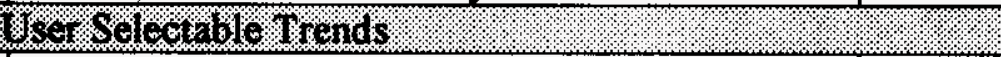 } \\
\hline 3. & $\begin{array}{l}\text { Click on a TREND } \\
\text { GRAPH button (located at } \\
\text { the bottom of the Tank } \\
\text { Workspace). }\end{array}$ & $\begin{array}{l}\text { Verify that a User Configurable Trend Graph } \\
\text { workspace appears. }\end{array}$ & \\
\hline 4. & $\begin{array}{l}\text { Click at random at several } \\
\text { places on the Trend Graph } \\
\text { workspace. }\end{array}$ & Verify that no menu appears. & \\
\hline 5. & $\begin{array}{l}\text { Attempt to move several } \\
\text { objects chosen at random } \\
\text { on the Trend Graph } \\
\text { workspace }\end{array}$ & Verify that no objects move. & \\
\hline 6. & $\begin{array}{l}\text { Click on the Hide Window } \\
\text { button on the Trend Graph } \\
\text { workspace. }\end{array}$ & Verify that the workspace disappears. & \\
\hline 7. & $\begin{array}{l}\text { Click on the Hide Window } \\
\text { button on the Tank Status } \\
\text { workspace. }\end{array}$ & Verify that the workspace disappears. & \\
\hline & 4.:- & Cument diarms & \\
\hline 8. & $\begin{array}{l}\text { Click on the CURRENT } \\
\text { ALARMS button on the } \\
\text { Control Panel. }\end{array}$ & $\begin{array}{l}\text { Verify that the Current Alarms workspace } \\
\text { appears. }\end{array}$ & \\
\hline 9. & $\begin{array}{l}\text { Click at random at several } \\
\text { places on the Current } \\
\text { Alarms workspace. }\end{array}$ & Verify that no menu appears. & \\
\hline 10. & $\begin{array}{l}\text { Attempt to move several } \\
\text { objects chosen at random } \\
\text { on the Current Alarms } \\
\text { workspace. }\end{array}$ & Verify that none move. & \\
\hline 11. & $\begin{array}{l}\text { Click on the Hide Window } \\
\text { button on the Current } \\
\text { Alarms workspace. }\end{array}$ & Verify that the workspace disappears. & \\
\hline
\end{tabular}

\subsubsection{Control Panel}

\subsubsection{Operation of the SHOW MAIN DISPLAY button}

\begin{tabular}{|l|l|l|l|}
\hline Step & \multicolumn{1}{|c|}{ Perform } & \multicolumn{1}{c|}{ Expected Result } & Initial \\
\hline 1. & $\begin{array}{l}\text { Click on any enabled Tank } \\
\text { Icon in the Hanford Tank } \\
\text { Farm Facilities. (The icon } \\
\text { will not be gray.) If the } \\
\text { Tank Status Window is not } \\
\text { already shrunk then click } \\
\text { it's Shrink Window button }\end{array}$ & $\begin{array}{l}\text { Verify that a Tank Status workspace appears } \\
\text { for the selected tank and that the Control Panel } \\
\text { is visible. }\end{array}$ & \\
\hline
\end{tabular}


HNF-3967, Rev. 4

\begin{tabular}{|c|c|c|c|}
\hline Step & Perform & Expected Result & Initial \\
\hline & (an $\nabla$ as a symbol). & & \\
\hline 2. & $\begin{array}{l}\text { Click on the Show Main } \\
\text { Display button on the } \\
\text { Control Panel. }\end{array}$ & $\begin{array}{l}\text { Verify that the Tank Status workspace } \\
\text { disappears. } \\
\text { Verify that the following workspaces appear on } \\
\text { the screen: } \\
\text { - Hanford Tank Farm Facilities } \\
\text { - Control Panel } \\
\text { - Most Recent Alarm (may be partially } \\
\text { covered by the Hanford Tank Farm } \\
\text { Facilities workspace) } \\
\text { - Monitored Systems } \\
\text { Note: Working window may appear if Data } \\
\text { Recovery is sill running. }\end{array}$ & \\
\hline \multirow[t]{6}{*}{3.} & $\begin{array}{l}\text { Examine the TMACS } \\
\text { display. }\end{array}$ & $\begin{array}{l}\text { Verify that the Control Panel workspace is } \\
\text { located in the upper right-hand corner. }\end{array}$ & \\
\hline & & $\begin{array}{l}\text { Verify that the following objects appear in the } \\
\text { workspace in order, top to bottom: } \\
\text { - Label "Control Panel" } \\
\text { - SHOW MAIN DISPLAY button } \\
\text { - CURRENT ALARMS button (Not } \\
\text { available to Telewindows" sessions) } \\
\text { - Number of Current Alarms digital display } \\
\text { - Number of Sensor Testing digital display } \\
\text { - HIDE SENSOR TRENDS button } \\
\text { - REPORT MENU button } \\
\text { - A date and time display }\end{array}$ & \\
\hline & & $\begin{array}{l}\text { Verify that MONITORED SYSTEMS } \\
\text { workspace is displayed on the middle right- } \\
\text { hand side of the screen and is displaying the } \\
\text { following: } \\
\text { - AY/AZ Exhauster } \\
\text { - C-106 Sluicing } \\
\text { - K-Basins }\end{array}$ & \\
\hline & & $\begin{array}{l}\text { Verify that the Most Recent Alarm workspace } \\
\text { is in the lower right-hand corner and that the } \\
\text { GOTO button appears at the top center of the } \\
\text { workspace. }\end{array}$ & \\
\hline & & $\begin{array}{l}\text { Verify that the Number of Current Alarms } \\
\text { digital display is located at the top right of the } \\
\text { Most Recent Alarm workspace. }\end{array}$ & \\
\hline & & $\begin{array}{l}\text { Verify that the Hanford Tank Farm Facilities } \\
\text { workspace occupies the left portion of the } \\
\text { screen. }\end{array}$ & \\
\hline
\end{tabular}




\begin{tabular}{|l|l|l|l|}
\hline Step & Perform & \multicolumn{1}{c|}{ Expected Result } & Initial \\
\hline & $\begin{array}{l}\text { Verify that a brown background appears behind } \\
\text { these workspaces and that no other workspaces } \\
\text { are visible. }\end{array}$ & \\
\hline
\end{tabular}

\subsubsection{Operation of CURRENT ALARMS Button and Screen}

Note: The CURRENT ALARMS button is not available in a Telewindows ${ }^{\infty}$ session. $^{2}$

\begin{tabular}{|c|c|c|c|}
\hline Step & Perform & Expected Result & Initial \\
\hline 1. & $\begin{array}{l}\text { Click on the CURRENT } \\
\text { ALARMS button on the } \\
\text { Control Panel. }\end{array}$ & $\begin{array}{l}\text { Verify that the Current Alarms workspace } \\
\text { appears on the left-hand side of the screen and } \\
\text { contains the following: } \\
\text { - HIDE WINDOW (with an x as a symbol) } \\
\text { - SHRINK WINDOW (an } \nabla \text { as a symbol) } \\
\text { - EXPAND WINDOW (an as a symbol) } \\
\text { - CURRENT-ALARMS title box } \\
\text { - UP ONE ALARM } \\
\text { - UP ONE PAGE } \\
\text { - REFRESH ALARMS } \\
\text { - DOWN ONE PAGE } \\
\text { - } \text { GOWN TO TOP of LIST } \\
\text { - GO TO END of LIST } \\
\text { - ACKNOWLEDGE ALL WHITE } \\
\text { ALARMS } \\
\text { ACKNOWLEDGE ALL BLUE } \\
\text { MESSAGES }\end{array}$ & \\
\hline \multicolumn{4}{|c|}{ 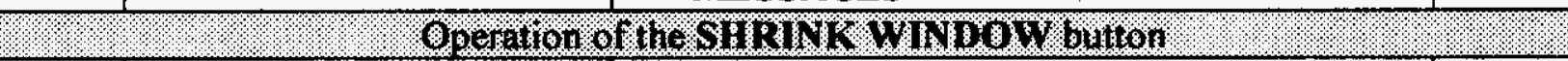 } \\
\hline 2. & $\begin{array}{l}\text { Note: If the Current } \\
\text { Alarms workspace is } \\
\text { already shrunk then } \\
\text { expand first. } \\
\text { Click on the SHRINK } \\
\text { WINDOW button. }\end{array}$ & $\begin{array}{l}\text { Verify the Current Alarms workspace: } \\
\text { - Decreases in size } \\
\text { - Moves to the left-hand side of the screen } \\
\text { - Has space to show } 10 \text { alarms. (Only } \\
9 \text { alarms will be visible if the first alarm in } \\
\text { the list is visible.) }\end{array}$ & \\
\hline \multicolumn{4}{|c|}{ 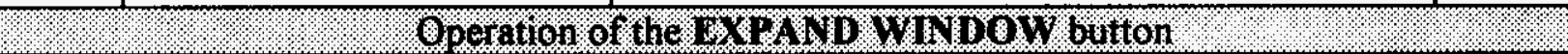 } \\
\hline 3. & $\begin{array}{l}\text { Click on the EXPAND } \\
\text { WINDOW button. }\end{array}$ & $\begin{array}{l}\text { Verify the Current Alarms workspace: } \\
\text { - Increases in size } \\
\text { - Moves to the left-hand side of the screen } \\
\text { - Has space to show } 6 \text { alarms. (Only } \\
5 \text { alarms will be visible if the first alarm in } \\
\text { the list is visible.) }\end{array}$ & \\
\hline & & IO OWD of I IST WWDOW button & \\
\hline
\end{tabular}




\begin{tabular}{|c|c|c|c|}
\hline Step & Perform & Expected Result & Initial \\
\hline 4. & $\begin{array}{l}\text { Click on the GO TO END } \\
\text { of LIST button }\end{array}$ & $\begin{array}{l}\text { Verify the last page of current alarms is } \\
\text { displayed }\end{array}$ & \\
\hline \multicolumn{4}{|c|}{ 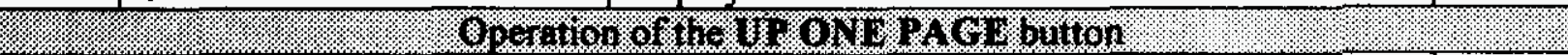 } \\
\hline 5. & $\begin{array}{l}\text { Click on the UP ONE } \\
\text { PAGE button. }\end{array}$ & $\begin{array}{l}\text { Verify the previous page of the current alarms } \\
\text { is displayed. }\end{array}$ & \\
\hline \multicolumn{4}{|c|}{ 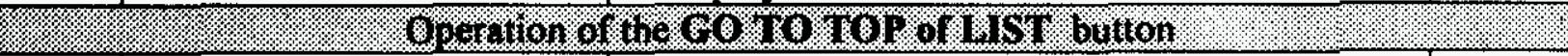 } \\
\hline 6. & $\begin{array}{l}\text { Click on the GO TO TOP } \\
\text { of LIST. }\end{array}$ & $\begin{array}{l}\text { Verify the first page of current alarms is } \\
\text { displayed. }\end{array}$ & \\
\hline \multicolumn{4}{|c|}{ 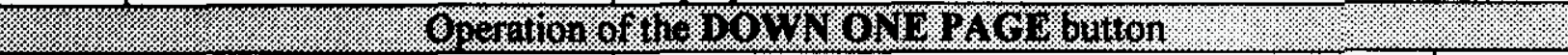 } \\
\hline 7. & $\begin{array}{l}\text { Click on the DOWN ONE } \\
\text { PAGE button. }\end{array}$ & $\begin{array}{l}\text { Verify the next page of current alarms is } \\
\text { displayed. }\end{array}$ & \\
\hline \multicolumn{4}{|c|}{ 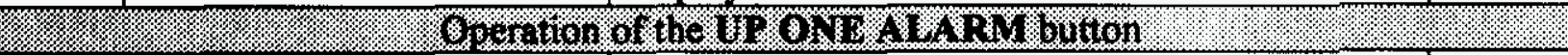 } \\
\hline 8. & $\begin{array}{l}\text { Click on the UP ONE } \\
\text { ALARM button. }\end{array}$ & $\begin{array}{l}\text { Verify that the alarm list is moved up one } \\
\text { alarm. }\end{array}$ & \\
\hline \multicolumn{4}{|c|}{ : } \\
\hline 9. & $\begin{array}{l}\text { Click on the DOWN ONE } \\
\text { ALARM button. }\end{array}$ & $\begin{array}{l}\text { Verify that the alarm list is moved down one } \\
\text { alarm. }\end{array}$ & \\
\hline \multicolumn{4}{|c|}{ O Operation of the WWTRESH N NRMS button } \\
\hline 10. & $\begin{array}{l}\text { Click on the REFRESH } \\
\text { ALARMS button. }\end{array}$ & Verify the alarm display is updated. & \\
\hline \multicolumn{4}{|c|}{ 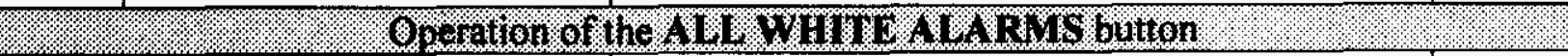 } \\
\hline 11. & $\begin{array}{l}\text { Click on the Acknowledge } \\
\text { ALL WHITE ALARMS } \\
\text { button. } \\
\text { (Note: May have to } \\
\text { generate white alarms } \\
\text { first) }\end{array}$ & $\begin{array}{l}\text { Verify the white alarms disappear from the } \\
\text { alarm list and that the Number of Current } \\
\text { Alarms is updated appropriately. }\end{array}$ & \\
\hline \multicolumn{4}{|c|}{ 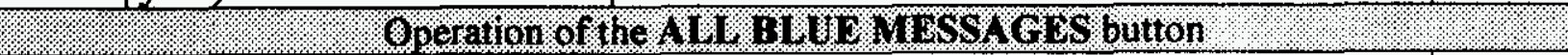 } \\
\hline 12. & $\begin{array}{l}\text { Click on the Acknowledge } \\
\text { ALL BLUE MESSAGES } \\
\text { button. } \\
\text { (Note: May have to } \\
\text { generate blue alarms first) }\end{array}$ & $\begin{array}{l}\text { Verify the blue messages disappear from the } \\
\text { alarm list. }\end{array}$ & \\
\hline \multicolumn{4}{|c|}{ 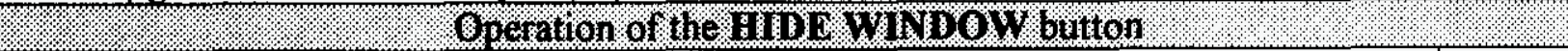 } \\
\hline 13. & $\begin{array}{l}\text { Click on the HIDE } \\
\text { WINDOW button }\end{array}$ & Verify that the workspace disappears & \\
\hline
\end{tabular}




\subsubsection{Operation of the HIDE SENSOR TRENDS button}

\begin{tabular}{|c|c|c|c|}
\hline Step & Perform & Expected Result & Initial \\
\hline 1. & $\begin{array}{l}\text { Click on an enabled Tank } \\
\text { Icon on the Hanford Tank } \\
\text { Farm Facilities workspace. } \\
\text { (The icon will not be gray.) }\end{array}$ & $\begin{array}{l}\text { Verify that the Tank Status workspace for this } \\
\text { tank appears. }\end{array}$ & \\
\hline 2. & $\begin{array}{l}\text { Click on several sensor } \\
\text { trend icons selected at } \\
\text { random. }\end{array}$ & $\begin{array}{l}\text { Verify that Sensor Trend workspaces for the } \\
\text { selected sensors appear. }\end{array}$ & \\
\hline 3. & $\begin{array}{l}\text { Lift the Control Panel to } \\
\text { the top by clicking in the } \\
\text { blank background on the } \\
\text { Control Panel workspace. } \\
\text { Click on the HIDE } \\
\text { SENSOR TRENDS button } \\
\text { on the Control Panel. }\end{array}$ & $\begin{array}{l}\text { Verify that the Tank Status workspace and any } \\
\text { Sensor Trend workspaces are hidden. }\end{array}$ & \\
\hline
\end{tabular}

\subsubsection{Operation of the REPORTS button}

\begin{tabular}{|c|c|c|c|}
\hline Step & Perform & Expected Result & Initial \\
\hline 1. & $\begin{array}{l}\text { Click on the REPORT } \\
\text { MENU button on the } \\
\text { Control Panel. }\end{array}$ & $\begin{array}{l}\text { Verify that the Report Menu workspace is } \\
\text { displayed with a list of report buttons that } \\
\text { includes the following: } \\
\text { - Suspect Sensor Report } \\
\text { - Suspect IO-Station Report } \\
\text { - Unknown Sensor Report } \\
\text { - ENRAF Non-Operating Mode Report } \\
\text { - Sensor Disable Alarm Report } \\
\text { - Sensor Enabled Test Report }\end{array}$ & \\
\hline 2. & $\begin{array}{l}\text { Select a report at random. } \\
\text { Click on the Title of the } \\
\text { report. }\end{array}$ & $\begin{array}{l}\text { Verify the Help workspace for the chosen } \\
\text { report is displayed. }\end{array}$ & \\
\hline 3. & Click on the hide button. & Verify the workspace disappears. & \\
\hline 4. & $\begin{array}{l}\text { Select a report at random } \\
\text { Click on the button for the } \\
\text { chosen report. }\end{array}$ & $\begin{array}{l}\text { Verify the chosen report's workspace is } \\
\text { displayed. (Note: The verification of the report } \\
\text { is performed elsewhere in this documem.) }\end{array}$ & \\
\hline 5. & Click on the hide button. & Verify the workspace disappears. & \\
\hline
\end{tabular}


HNF-3967, Rev. 4

\begin{tabular}{|l|l|l|c|}
\hline Step & \multicolumn{1}{|c|}{ Perform } & \multicolumn{1}{c|}{ Expected Result } & Initial \\
\hline 6. & $\begin{array}{l}\text { Click on the hide button on } \\
\text { Report Menu workspace. }\end{array}$ & Verify the workspace disappears. & \\
\hline
\end{tabular}

\subsubsection{Hanford Tank Farm Facility}

\subsubsection{Operation of a TANK ICON button}

\begin{tabular}{|c|c|c|c|}
\hline Step & Perform & Expected Result & Initial \\
\hline \multirow[t]{2}{*}{1.} & \multirow[t]{2}{*}{$\begin{array}{l}\text { Click any enabled Tank } \\
\text { Icon in the Hanford Tank } \\
\text { Farm Facilities. (The icon } \\
\text { will not be gray.) }\end{array}$} & $\begin{array}{l}\text { Verify that the Tank Status workspace appears } \\
\text { on the screen and contains the following: } \\
\text { - TITLE (correctly identifying the tank) } \\
\text { - HIDE WINDOW button ( } x \text { as a symbol) } \\
\text { - SHRINK WINDOW button (an } \nabla \text { as a } \\
\text { symbol) } \\
\text { - EXPAND WINDOW button (an } \triangle \text { as a } \\
\text { symbol) } \\
\text { ACK ALARMS button }\end{array}$ & \\
\hline & & $\begin{array}{l}\text { - UPDATE button (if available, not all tanks } \\
\text { have discrete sensors). } \\
\text { - Riser Location Drawing (Refer to the } \\
\text { appropriate Tank Riser Configuration } \\
\text { Documents for correct location) } \\
\text { - Print Screen button } \\
\text { - Riser Identifier(s) (displayed over the } \\
\text { riser(s)) } \\
\text { - Sensor lcons (i.e. thermocouple, level) } \\
\text { - User Selectable Trend button(s). }\end{array}$ & \\
\hline \multicolumn{4}{|c|}{ (1) } \\
\hline 2. & $\begin{array}{l}\text { Use the document } \\
\text { "TMACS V/O Termination } \\
\text { Point Listing" (Tag list) as } \\
\text { a reference. Choose a } \\
\text { thermocouple for the tank. }\end{array}$ & $\begin{array}{l}\text { Verify the following: } \\
\text { - The thermocouple is positioned on the tank } \\
\text { display in a way that approximates the } \\
\text { physical location in the tank. } \\
\text { - Sensor label and current value are displayed } \\
\text { next to the thermocouple icon } \\
\text { - Sensor icon is overlaid with the sensor } \\
\text { alarm status color }\end{array}$ & \\
\hline
\end{tabular}




\begin{tabular}{|c|c|c|c|}
\hline Step & Perform & Expected Result & Initial \\
\hline \multicolumn{4}{|c|}{ Operation of Tank L Level Indikation } \\
\hline 3. & $\begin{array}{l}\text { Use the document } \\
\text { "TMACS I/O Termination } \\
\text { Point Listing" (Tag list) as } \\
\text { a reference. Choose a } \\
\text { surface level sensor for the } \\
\text { tank. }\end{array}$ & $\begin{array}{l}\text { Verify the following: } \\
\text { The surface level icon(s) is positioned } \\
\text { proportionally to the maximum tank height } \\
\text { and at the current level displayed by the } \\
\text { reading. } \\
\text { - Sensor label and current value are displayed } \\
\text { next to the surface level icon. The label } \\
\text { should identifying the source of this } \\
\text { reading. (ENRAF or SACS) } \\
\text { - Sensor icon is overlaid with the sensor } \\
\text { alarm status color }\end{array}$ & \\
\hline \multicolumn{4}{|c|}{$\begin{array}{l}\text { Operation of Print bution } \\
\text { Not avallable in a } T \text { lelewindows' session }\end{array}$} \\
\hline 4. & $\begin{array}{l}\text { Click on the PRINT } \\
\text { SCREEN button. }\end{array}$ & Verify that the tank workspace prints. & \\
\hline \multicolumn{4}{|c|}{ Operation of Strink Window button } \\
\hline 5. & $\begin{array}{l}\text { Click on the SHRINK } \\
\text { WINDOW button (an } \nabla \text { as } \\
\text { a symbol). }\end{array}$ & Verify that the workspace shrinks. & \\
\hline 6. & $\begin{array}{l}\text { Drag the Tank Status } \\
\text { workspace to the upper } \\
\text { right hand corner. }\end{array}$ & $\begin{array}{l}\text { Verify that the Tank Status workspace stops at } \\
\text { the edge of the screen when dragged to the top } \\
\text { or to the right. }\end{array}$ & \\
\hline \multicolumn{4}{|c|}{ Operation of Expand Window button } \\
\hline 7. & $\begin{array}{l}\text { Click on the EXPAND } \\
\text { WINDOW button (an } 4 \\
\text { as a symbol). }\end{array}$ & Verify that the workspace enlarges. & \\
\hline \multicolumn{4}{|c|}{ Operation of the MIBE button } \\
\hline 8. & $\begin{array}{l}\text { Click on the HIDE } \\
\text { WINDOW. }\end{array}$ & Verify that the workspace is hidden. & \\
\hline \multicolumn{4}{|c|}{$\begin{array}{l}\text { Note: Operation of the Acknowledge Alarm button is performed in section } 6.6 .7 \text { (Miscellaneous } \\
\text { Alarm Tests) }\end{array}$} \\
\hline
\end{tabular}

\subsubsection{Operation Of The HTFF Print Button}

Note: The CURRENT ALARMS button is not available in a Telewindows $\circledast$ session.

\begin{tabular}{|l|l|l|l|}
\hline Step & \multicolumn{1}{|c|}{ Perform } & \multicolumn{1}{c|}{ Expected Result } & Initial \\
\hline 1. & $\begin{array}{l}\text { Click on the PRINT } \\
\text { SCREEN button in the } \\
\text { lower right hand corner of } \\
\text { workspace. May have to }\end{array}$ & Verify that the workspace is printed. & \\
\hline
\end{tabular}


HNF-3967, Rev. 4

\begin{tabular}{|c|l|c|c|}
\hline Step & \multicolumn{1}{|c|}{ Perform } & Expected Result & Initial \\
\hline & $\begin{array}{l}\text { click on HTTF workspace } \\
\text { to see button) }\end{array}$ & & \\
\hline
\end{tabular}

\subsubsection{Monitored Systems}

\subsubsection{Operation Of The Monitored System Button}

\begin{tabular}{|c|c|c|c|}
\hline Step & Perform & Expected Result & Initial \\
\hline 1. & $\begin{array}{l}\text { Click on the any system } \\
\text { displayed on the } \\
\text { MONITORED SYSTEMS } \\
\text { workspace. }\end{array}$ & $\begin{array}{l}\text { Verify that a workspace is displayed } \\
\text { representing the monitored system. }\end{array}$ & \\
\hline 2. & $\begin{array}{l}\text { Click on the sensor } \\
\text { objects. }\end{array}$ & $\begin{array}{l}\text { Verify that no graphic workspaces or menu } \\
\text { boxes are displayed. }\end{array}$ & \\
\hline 3. & $\begin{array}{l}\text { For alarm panels, click on } \\
\text { any graphic "borders". }\end{array}$ & $\begin{array}{l}\text { Verify that no graphic workspaces or menu } \\
\text { boxes are displayed. }\end{array}$ & \\
\hline \multicolumn{4}{|c|}{ Opertion of Shrink Window button } \\
\hline & $\begin{array}{l}\text { Click on the SHRINK } \\
\text { WINDOW button (an } \nabla \text { as } \\
\text { a symbol). }\end{array}$ & Verify that the workspace shrinks. & \\
\hline & $\begin{array}{l}\text { Drag the workspace to the } \\
\text { upper right hand corner. }\end{array}$ & $\begin{array}{l}\text { Verify that the workspace stops at the edge of } \\
\text { the screen when dragged to the top or to the } \\
\text { right. }\end{array}$ & \\
\hline \multicolumn{4}{|c|}{ Operation of Expand Window buttion } \\
\hline & $\begin{array}{l}\text { Click on the EXPAND } \\
\text { WINDOW button (an } \\
\text { as a symbol). }\end{array}$ & Verify that the workspace enlarges. & \\
\hline \multicolumn{4}{|c|}{ Operation of the MIDE bution } \\
\hline & $\begin{array}{l}\text { Click on the HIDE } \\
\text { WINDOW. }\end{array}$ & Verify that the workspace is hidden. & \\
\hline
\end{tabular}

\subsection{TRENDING}

This section describes the test cases for both the individual and user selectable trends.

Have the Test Director verify that the TMACS is running in Development Mode of operation and is generating variable sensor data. Note: $\mathrm{G} 2^{\infty}$ will only display trend data that varies over time.

\subsubsection{Operation of Individual Sensor Trends}

This section describes the test cases for the individual selectable trends. 


\subsubsection{Operation of Trend Chart}

\begin{tabular}{|c|c|c|c|}
\hline Step & Perform & Expected Result & Initial \\
\hline 1. & $\begin{array}{l}\text { Click any enabled Tank Icon } \\
\text { in the Hanford Tank Farm } \\
\text { Facilities. (The icon will not } \\
\text { be gray.) } \\
\text { Click on the portion of any } \\
\text { sensor icon that looks like a } \\
\text { little chart. }\end{array}$ & $\begin{array}{l}\text { Verify that a Sensor Trend workspace for the } \\
\text { sensor chosen and contains the following. } \\
\text { - Chart } \\
\text { - HIDE WINDOW }(X) \text { button } \\
\text { - DETAIL }(D) \text { button. } \\
\text { - PRINT }(P) \text { button }\end{array}$ & \\
\hline 2. & Examine the Chart. & $\begin{array}{l}\text { Verify the following: } \\
\text { - The values line color is black. } \\
\text { - Lines for the low and high alarm limits } \\
\text { appear at roughly one-tenth }(1 / 10) \text { and } \\
\text { nine tenths }(9 / 10) \text { of the distance on the } \\
\text { vertical axis. Note: Only if trend is } \\
\text { within limits. } \\
\text { - Alarm limit bands match the alarm color } \\
\text { (Yellow or Red). } \\
\text { The trend title (above) and label (below) } \\
\text { agree with the sensor tag name and } \\
\text { descriptor. } \\
\text { The time scale of the horizontal time axis } \\
\text { is } 7 \text { days and that some dates are shown. }\end{array}$ & \\
\hline 3 . & Click on the Print button. & $\begin{array}{l}\text { Verify the Sensor Trend workspace is } \\
\text { printed. }\end{array}$ & \\
\hline 4. & $\begin{array}{l}\text { Click on the HIDE } \\
\text { WINDOW button. }\end{array}$ & Verify that the workspace is hidden. & \\
\hline
\end{tabular}

\subsubsection{Operation of Sensor Details}

\begin{tabular}{|l|l|l|l|}
\hline Step & \multicolumn{1}{|c|}{ Perform } & \multicolumn{1}{c|}{ Expected Result } & Initial \\
\hline 1. & $\begin{array}{l}\text { Select a } \\
\text { continuous sensor } \\
\text { that has polling } \\
\text { enabled at random. } \\
\text { Display the } \\
\text { individual sensor } \\
\text { trend chart for the } \\
\text { chosen sensor. }\end{array}$ & $\begin{array}{l}\text { Verify the trend chart is displayed and the tag name is } \\
\text { displayed above the trend chart }\end{array}$ & \\
\hline 2. & $\begin{array}{l}\text { Click on the } \\
\text { Details (D) button. }\end{array}$ & $\begin{array}{l}\text { Verify the Sensor Details workspace for the chosen sensor } \\
\text { is displayed with the following information: }\end{array}$ &
\end{tabular}


HNF-3967, Rev. 4

\begin{tabular}{|c|c|c|c|c|}
\hline Step & Perform & \multicolumn{2}{|c|}{ Expected Result } & Initial \\
\hline & & \multicolumn{2}{|c|}{$\begin{array}{l}\text { Hide }(X) \text { button } \\
\text { Print }(\mathrm{P}) \text { button } \\
\text { Update }(J) \text { button } \\
\text { Test }(T) \text { button } \\
\text { Note: Sensor must have point processing enabled for the } \\
\text { Test buttons to be displayed.) } \\
\text { And depending on the sensor type one of the following } \\
\text { sensor information groups. }\end{array}$} & \\
\hline \multicolumn{5}{|c|}{ 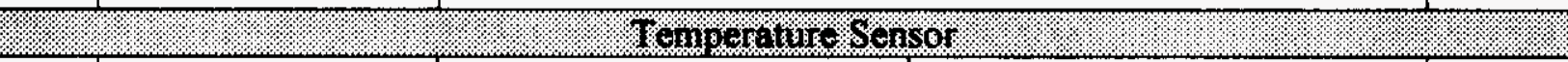 } \\
\hline & & $\begin{array}{l}\text { Current Reading } \\
\text { Last Good Reading } \\
\text { Quality Status } \\
\text { Units } \\
\text { High Alarm Limit } \\
\text { Low Alarm Limit } \\
\text { Deadband } \\
\text { Point Processing } \\
\text { ROC Processing } \\
\text { Station Status } \\
\text { Polling Freq. Index } \\
\text { Validity Interval } \\
\text { Expiration Time } \\
\text { Formula Expression } \\
\text { Formula Parameter }\end{array}$ & $\begin{array}{l}\text { Last Update Method } \\
\text { Test Processing } \\
\text { Type } \\
\text { Upper Instrument Limit } \\
\text { Lower Instrument Limit } \\
\text { Delta } \\
\text { Alarm Processing } \\
\text { Logging } \\
\text { Raw Value } \\
\text { Polling. Freq. Sec. }\end{array}$ & \\
\hline \multicolumn{5}{|c|}{ SACS LEVEI Sensor } \\
\hline & & $\begin{array}{l}\text { Current Reading } \\
\text { Last Good Reading } \\
\text { Quality Status } \\
\text { Units } \\
\text { High Alarm Limit } \\
\text { Low Alarm Limit } \\
\text { Deadband } \\
\text { Point Processing } \\
\text { ROC Processing } \\
\text { Suspect Status } \\
\text { Sensor Type Name } \\
\text { Slvl_dttm }\end{array}$ & $\begin{array}{l}\text { Last Update Method } \\
\text { Test Processing } \\
\text { Upper Instrument Limit } \\
\text { Lower Instrument Limit } \\
\text { Delta } \\
\text { Alarm Processing } \\
\text { Logging }\end{array}$ & \\
\hline \multicolumn{5}{|c|}{ DNR / F W WEL Sensor } \\
\hline & & $\begin{array}{l}\text { Current Reading } \\
\text { Last Good Reading } \\
\text { Quality Status } \\
\text { Units }\end{array}$ & $\begin{array}{l}\text { Last Update Method } \\
\text { Test Processing } \\
\text { Upper Instrument Limit }\end{array}$ & \\
\hline
\end{tabular}


HNF-3967, Rev. 4

\begin{tabular}{|c|c|c|c|c|}
\hline Step & Perform & \multicolumn{2}{|c|}{ Expected Result } & Initial \\
\hline & & $\begin{array}{l}\text { High Alarm Limit } \\
\text { Low Alarm Limit } \\
\text { Deadband } \\
\text { Point Processing } \\
\text { ROC Processing } \\
\text { Station Status } \\
\text { Polling Freq. Index } \\
\text { Displacer Position } \\
\text { Level Status } \\
\text { Alarm Status } \\
\text { Validity Interval } \\
\text { Expiration Time } \\
\text { Formula Expression } \\
\text { Formula Parameter }\end{array}$ & $\begin{array}{l}\text { Lower Instrument Limit } \\
\text { Delta } \\
\text { Alarm Processing } \\
\text { Logging } \\
\text { Raw Value } \\
\text { Polling. Freq. Sec. } \\
\text { Waste Level } \\
\text { Level Status Mode } \\
\text { Alarm Status Mode }\end{array}$ & \\
\hline \multicolumn{5}{|c|}{ Other Sensors } \\
\hline & & $\begin{array}{l}\text { Current Reading } \\
\text { Last Good Reading } \\
\text { Quality Status } \\
\text { Units } \\
\text { High Alarm Limit } \\
\text { Low Alarm Limit } \\
\text { Deadband } \\
\text { Point Processing } \\
\text { ROC Processing } \\
\text { Station Status } \\
\text { Polling Freq. Index } \\
\text { Validity Interval } \\
\text { Expiration Time } \\
\text { Formula Expression } \\
\text { Formula Parameter }\end{array}$ & $\begin{array}{l}\text { Last Update Method } \\
\text { Test Processing } \\
\text { Upper Instrument Limit } \\
\text { Lower Instrument Limit } \\
\text { Delta } \\
\text { Alarm Processing } \\
\text { Logging } \\
\text { Raw Value } \\
\text { Polling. Freq. Sec. }\end{array}$ & \\
\hline 3. & $\begin{array}{l}\text { Click the Update } \\
\text { button. } \\
\text { Wait for the } \\
\text { workspace to be } \\
\text { updated } \\
\text { (approximately } 5 \\
\text { seconds). }\end{array}$ & \multicolumn{2}{|c|}{$\begin{array}{l}\text { Verify the following: } \\
\text { - The date and time displayed in the Readout Last } \\
\text { Good Reading At is updated. } \\
\text { - Reading displayed in the Current Reading is updated. } \\
\text { - RPC is displayed in the readout labeled Last Update } \\
\text { Method } \\
\text { Note: The readout labeled Last Ipdate Method will } \\
\text { change to poll when next poll is taken. } \\
\text { Note: An alarm could be generated if the reading for the } \\
\text { sensor is an alarm range. } \\
\text { Note: the current Reading may or may not change } \\
\text { depending if the value being read has changed. }\end{array}$} & \\
\hline
\end{tabular}




\begin{tabular}{|c|c|c|c|}
\hline Step & Perform & Expected Result & Initial \\
\hline & & $\begin{array}{l}\text { Note: If sensor has point-processing disabled then only the } \\
R A W \text { VALUE and the EXPIRATION TIME will be } \\
\text { updated. }\end{array}$ & \\
\hline 4. & $\begin{array}{l}\text { Wait until the next } \\
\text { time the sensor is } \\
\text { polled. } \\
\text { Note: The } \\
\text { SACS_LEVEL } \\
\text { sensors are only } \\
\text { polled once a day } \\
\text { at approximately } \\
\text { 8:00 PM }\end{array}$ & $\begin{array}{l}\text { Verify the following: } \\
\text { - The date and time displayed in the Readout Last } \\
\text { Good Reading At is updated. } \\
\text { - Reading displayed in the Current Reading is updated. } \\
\text { - POLL is displayed in the readout labeled Last Update } \\
\text { Method } \\
\text { Note: An alarm could be generated if the reading for the } \\
\text { sensor is an alarm range. } \\
\text { Note: the current Reading may or may not change } \\
\text { depending if the value being read has changed. } \\
\text { Note: The Readout Last Good Reading At will only be } \\
\text { updated if the reading value changes by more than the } \\
\text { delta. }\end{array}$ & \\
\hline 5. & $\begin{array}{l}\text { Using the } \\
\text { emulator change } \\
\text { the value that is } \\
\text { read for the } \\
\text { sensor. } \\
\text { Press the Update } \\
\text { button. } \\
\text { Wait for the } \\
\text { workspace to be } \\
\text { updated } \\
\text { (approximately } 5 \\
\text { seconds). }\end{array}$ & $\begin{array}{l}\text { Verify the following: } \\
\text { - The date and time displayed in the Readout Last } \\
\text { Good Reading At is updated. } \\
\text { - Reading displayed in the Current Reading is updated } \\
\text { to the value issued by the emulator. } \\
\text { - RPC is displayed in the readout labeled Last Update } \\
\text { Method } \\
\text { Note: The readout labeled Last Update Method will } \\
\text { change to poll when next poll is taken. } \\
\text { Note: An alarm could be generated if the reading for the } \\
\text { sensor is an alarm range. }\end{array}$ & \\
\hline 6. & $\begin{array}{l}\text { Wait until the next } \\
\text { time the sensor is } \\
\text { polled. }\end{array}$ & $\begin{array}{l}\text { Verify the following: } \\
\text { - The date and time displayed in the Readout Last } \\
\text { Good Reading At is updated. } \\
\text { - Reading displayed in the Current Reading is updated. } \\
\text { - POLL is displayed in the readout labeled Last Update } \\
\text { Method } \\
\text { Note: The Readout Last Good Reading At will only be } \\
\text { updated if the reading value changes by more than the } \\
\text { delta. }\end{array}$ & \\
\hline
\end{tabular}


HNF-3967, Rev. 4

\begin{tabular}{|c|c|c|c|}
\hline Step & Perform & Expected Result & Initial \\
\hline 7. & $\begin{array}{l}\text { Click the TEST } \\
\text { button. }\end{array}$ & $\begin{array}{l}\text { Verify the following on the Sensor Details workspace: } \\
\text { - Quality Status is set to TEST Note: Unless the status } \\
\text { is UNKNOWN) } \\
\text { - Testing Processing is set to true } \\
\text { Verify on the Current Alarms workspace that a blue } \\
\text { message is generated with the following information } \\
\text { - Date and Time when place in test mode } \\
\text { - Sensor Tag Name } \\
\text { Description - The TESTING PROCESS of [Tag } \\
\text { Name] has been ENABLED } \\
\text { Verify on the Control Panel that the Number of Sensors } \\
\text { Testing increase by } 1 \text {. }\end{array}$ & \\
\hline 8 . & $\begin{array}{l}\text { Click on the } \\
\text { Update button a } \\
\text { few times (more } \\
\text { than once) } \\
\text { Examine the } \\
\text { appropriate sensor } \\
\text { history file. } \\
\text { To examine the } \\
\text { file it may be } \\
\text { necessary to stop } \\
\text { G2. The } \\
\text { directory is } \\
\text { located at } \\
\text { f: Backed } \text { Bp } \backslash 7 \mathrm{MA} \\
\text { CSDatalCurrent. }\end{array}$ & $\begin{array}{l}\text { Verify the Quality Status for the readings chosen sensor } \\
\text { while in test mode is indicated as TEST. }\end{array}$ & \\
\hline 9. & $\begin{array}{l}\text { Click the TEST } \\
\text { button. }\end{array}$ & $\begin{array}{l}\text { Verify the following on the Sensor Details workspace: } \\
\text { - Quality Status is set to GOOD (Note: Imless the status } \\
\text { is }(I N K N O W N \text { ) } \\
\text { - Testing Processing is set to false } \\
\text { Verify on the Current Alarms workspace that a blue } \\
\text { message is generated with the following information } \\
\text { - Date and Time when place taken out of test mode } \\
\text { - Sensor Tag Name }\end{array}$ & \\
\hline
\end{tabular}




\begin{tabular}{|c|c|c|c|}
\hline Step & Perform & Expected Result & Initial \\
\hline & & $\begin{array}{l}\text { Description - The TESTING PROCESS of [Tag } \\
\text { Name] has been DISABLED } \\
\text { Verify on the Control Panel that the Number of Sensors } \\
\text { Testing decreases by } 1 \text {. }\end{array}$ & \\
\hline 10. & $\begin{array}{l}\text { Click on the Print } \\
\text { button. }\end{array}$ & Verify the Sensor Details workspace is printed. & \\
\hline 11. & $\begin{array}{l}\text { Click on the Hide } \\
\text { button }\end{array}$ & Verify the Sensor Details workspace disappears. & \\
\hline
\end{tabular}

\subsubsection{Operation of Sensor History}

\begin{tabular}{|c|c|c|c|}
\hline Step & Perform & Expected Result & Initial \\
\hline 1. & $\begin{array}{l}\text { Select a continuous sensor } \\
\text { at random that has history. } \\
\text { Display the individual } \\
\text { sensor trend chart for the } \\
\text { chosen sensor. }\end{array}$ & $\begin{array}{l}\text { Verify the trend chart is displayed and the tag } \\
\text { name is displayed above the trend chart }\end{array}$ & \\
\hline 2. & Click on the trend chart. & 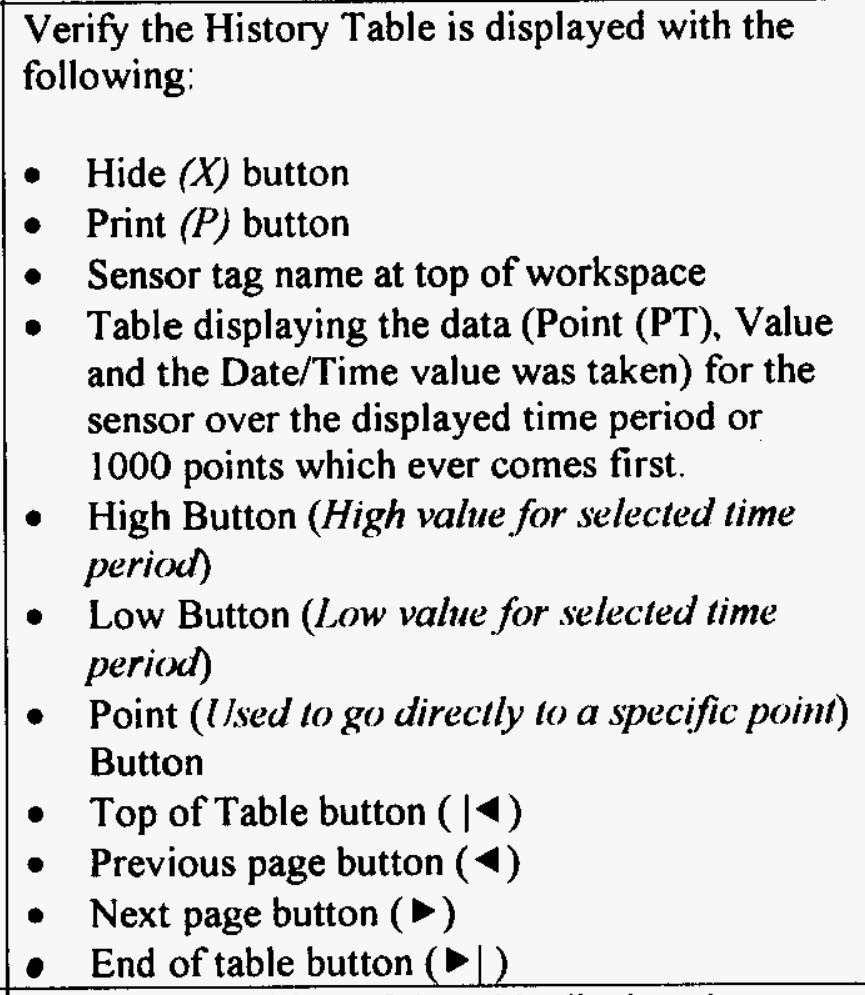 & \\
\hline 3. & Click on the High button & $\begin{array}{l}\text { Verify the position of the table displayed } \\
\text { contains the sensor point with the highest value. }\end{array}$ & \\
\hline 4. & Click on the Low button & Verify the position of the table displayed & \\
\hline
\end{tabular}


HNF-3967, Rev. 4

\begin{tabular}{|c|c|c|c|}
\hline Step & Perform & Expected Result & Initial \\
\hline & & contains the sensor point with the lowest value. & \\
\hline 5. & $\begin{array}{l}\text { Chose a sensor point at } \\
\text { random. } \\
\text { Enter this point in the text } \\
\text { box associated with the } \\
\text { Point button. } \\
\text { Click on the Point button. }\end{array}$ & $\begin{array}{l}\text { Verify the position of the table displayed } \\
\text { contains the sensor point chosen. }\end{array}$ & \\
\hline 6. & $\begin{array}{l}\text { Click on the top of table } \\
\text { button }(\mid<) \text {. }\end{array}$ & $\begin{array}{l}\text { Verify that the portion of the table displayed is } \\
\text { the first page in the table. }\end{array}$ & \\
\hline 7. & $\begin{array}{l}\text { Click on the end of table } \\
\text { button }(\bullet 1) \text {. }\end{array}$ & $\begin{array}{l}\text { Verify the portion of the table displayed is the } \\
\text { last page in the table. }\end{array}$ & \\
\hline 8. & $\begin{array}{l}\text { Click the previous page } \\
\text { button }(\triangleleft)\end{array}$ & $\begin{array}{l}\text { Verify the portion of the table displayed is the } \\
\text { previous page. }\end{array}$ & \\
\hline 9. & $\begin{array}{l}\text { Click the next page button } \\
(\triangleright)\end{array}$ & $\begin{array}{l}\text { Verify the portion of the table displayed is the } \\
\text { next page. }\end{array}$ & \\
\hline 10. & Click on the Print button. & Verify the Sensor History workspace is printed. & \\
\hline 11. & Click on the table. & $\begin{array}{l}\text { Verify the history details workspace is displayed } \\
\text { with the following information: } \\
\text { - Hide }(\mathrm{X}) \text { button } \\
\text { - Print (P) button } \\
\text { - Sensor Tag Name at top of workspace } \\
\text { - Total Point Count (signifies the total number } \\
\text { of points in history) } \\
\text { - Time Interval Point Count (signifies the } \\
\text { mumber of points display in history table and } \\
\text { trend chart for the selected time period) } \\
\text { - High Point Number } \\
\text { - High Value } \\
\text { - High Date/Time } \\
\text { - Low Point Number } \\
\text { - Low Value } \\
\text { - Low Date/Time } \\
\text { - Select Time Interval } \\
\text { - } 1 \text { hour } \\
\text { - } 8 \text { hours } \\
\text { - } 24 \text { hours } \\
\text { - } 7 \text { days } \\
\text { - } 31 \text { days }\end{array}$ & \\
\hline 12 . & $\begin{array}{l}\text { Select a time interval at } \\
\text { random. }\end{array}$ & Verify the following workspaces are updated: & \\
\hline
\end{tabular}


HNF-3967, Rev. 4

\begin{tabular}{|l|l|l|l|}
\hline Step & \multicolumn{1}{|c|}{ Perform } & \multicolumn{1}{|c|}{ Expected Result } & Initial \\
\hline 13. & Click on the Print button. & $\begin{array}{l}\text { - Individual Sensor Trend Chart } \\
\text { History Table } \\
\text { Vistory Details }\end{array}$ & \\
\hline 14. & $\begin{array}{l}\text { Click on the Hide button } \\
\text { for the Individual Sensor } \\
\text { Trend workspace. }\end{array}$ & $\begin{array}{l}\text { Verify the following workspaces disappear: } \\
\text { - Individual Sensor Trend Chart }\end{array}$ & \\
& & $\begin{array}{l}\text { History Table } \\
\text { History Details }\end{array}$ & \\
\hline
\end{tabular}

\subsubsection{Operation of User Selectable trends}

This section describes the test cases for the individual selectable trends.

Note: User selectable sensor trends cannot be performed in a Telewindows $®$ session.

\begin{tabular}{|c|c|c|c|}
\hline Step & Perform & Expected Result & Initial \\
\hline 1. & $\begin{array}{l}\text { Click any enabled Tank } \\
\text { Icon in the Hanford Tank } \\
\text { Farm Facilities. (The icon } \\
\text { will not be gray.) } \\
\text { Click on a USER } \\
\text { SELECTABLE TRENDS } \\
\text { button. (located at the } \\
\text { bottom of the Tank Status } \\
\text { workspace.) }\end{array}$ & $\begin{array}{l}\text { Verify that the USER SELECTABLE TRENDS } \\
\text { workspace appears and contains the following. } \\
\text { - Title (identifying what Tank trend is } \\
\text { associated with) } \\
\text { - Trend graph or chart. } \\
\text { - HIDE WINDOW button (with an x as a } \\
\text { symbol) } \\
\text { - SHRINK WINDOW button (an } \nabla \text { as a } \\
\text { symbol) } \\
\text { - EXPAND WINDOW button (an } \triangle \text { as a } \\
\text { - } \text { symbol) } \\
\text { - PRINT SCREEN button } \\
\text { - UPDATE GRAPH button (below the } \\
\text { graph). } \\
\text { - SELECT TIME INTERVAL OPTIONS } \\
\text { - } 1 \text { hour } \\
\text { - } 8 \text { hours } \\
\text { - } 7 \text { hours } \\
\text { - } 31 \text { days. } \\
\text { - List of sensors associated with user } \\
\text { - Chectable trend with the following } \\
\text { - } \text { on graph/chart) } \\
\text { - Sensor symbol (identifies sensor on } \\
\text { graph/chart) }\end{array}$ & \\
\hline
\end{tabular}


HNF-3967, Rev. 4

\begin{tabular}{|c|c|c|c|}
\hline Step & Perform & Expected Result & Initial \\
\hline & & $\begin{array}{l}\text { - Current, Low, and High readings (based on } \\
\text { the SELECT TIME INTERVAL chosen.) } \\
\text { - Sensor Reading Description containing the } \\
\text { following information } \\
\text { - Type of readings (i.e. temperature) } \\
\text { - Time period of readings (based on the } \\
\text { SELECT TIME INTERVAL chosen) } \\
\text { - Units of readings (i.e. Degrees Fahrenheit) } \\
\text { - Date and Time }\end{array}$ & \\
\hline 2. & $\begin{array}{l}\text { Click on the UPDATE } \\
\text { GRAPH button }\end{array}$ & $\begin{array}{l}\text { Verify the Graph/Chart has the following: } \\
\text { - The current value for each sensor on the } \\
\text { trend graph approximates the current value } \\
\text { on the digital display. } \\
\text { - The values line matches the symbol for } \\
\text { each sensor. } \\
\text { - Trend graph label (below the x-axis of the } \\
\text { graph) reads: } \\
\text { "TANK xx-yyy SELECTED SENSORS } \\
\text { INDICATED BY X" } \\
\text { Where "xx-yyy" represents the name of the } \\
\text { tank. } \\
\text { - The time scale of the horizontal time axis is } \\
\text { based on the SELECT TIME INTERVAL } \\
\text { chosen. }\end{array}$ & \\
\hline \multicolumn{4}{|c|}{ \% } \\
\hline 3. & $\begin{array}{l}\text { Click on the box of any } \\
\text { sensor that contains an } X \text {. }\end{array}$ & Verify that the $\mathrm{X}$ is removed from the box. & \\
\hline 4. & $\begin{array}{l}\text { Click on the UPDATE } \\
\text { GRAPH button below the } \\
\text { graph. }\end{array}$ & $\begin{array}{l}\text { Verify the trend graph displays only lines for } \\
\text { the sensors that are checked. }\end{array}$ & \\
\hline 5. & $\begin{array}{l}\text { Click on the box of any } \\
\text { sensor that does not } \\
\text { contain an X. }\end{array}$ & Verify that the $\mathrm{X}$ is displayed in the box. & \\
\hline 6. & $\begin{array}{l}\text { Click on the UPDATE } \\
\text { GRAPH button below the } \\
\text { graph. }\end{array}$ & $\begin{array}{l}\text { Verify the trend graph displays only lines for } \\
\text { the sensors that are checked. }\end{array}$ & \\
\hline \multicolumn{4}{|c|}{ (vi, } \\
\hline 7. & $\begin{array}{l}\text { Click any "SELECT TIME } \\
\text { INTERVAL" option. }\end{array}$ & $\begin{array}{l}\text { Verify the following: } \\
\text { A black dot appears in the circle of the time } \\
\text { interval selected. } \\
\text { - The Sensor Reading Description is }\end{array}$ & \\
\hline
\end{tabular}




\begin{tabular}{|c|c|c|c|}
\hline Step & Perform & Expected Result & Initial \\
\hline & & $\begin{array}{l}\text { modified according to the SELECT TIME } \\
\text { INTERVAL chosen. (Note: Trend graph is } \\
\text { not updated automatically) }\end{array}$ & \\
\hline 8. & $\begin{array}{l}\text { Click on the UPDATE } \\
\text { GRAPH button below the } \\
\text { graph. }\end{array}$ & $\begin{array}{l}\text { Verify the horizontal time scale of the trend } \\
\text { graph is reset to the SELECT TIME } \\
\text { INTERVAL chosen. }\end{array}$ & \\
\hline \multicolumn{4}{|c|}{. } \\
\hline 9. & $\begin{array}{l}\text { Click on the SHRINK } \\
\text { WINDOW button (an } \nabla \text { as } \\
\text { a symbol). }\end{array}$ & Verify that the workspace shrinks. & \\
\hline 10 . & $\begin{array}{l}\text { Drag the workspace to the } \\
\text { upper right hand corner. }\end{array}$ & $\begin{array}{l}\text { Verify that the workspace stops at the edge of } \\
\text { the screen when dragged to the top or to the } \\
\text { right. }\end{array}$ & \\
\hline \multicolumn{4}{|c|}{ Operation of Gxoand Window button } \\
\hline 11. & $\begin{array}{l}\text { Click on the EXPAND } \\
\text { WINDOW button (an } \\
\text { as a symbol). }\end{array}$ & Verify that the workspace enlarges. & \\
\hline \multicolumn{4}{|c|}{ 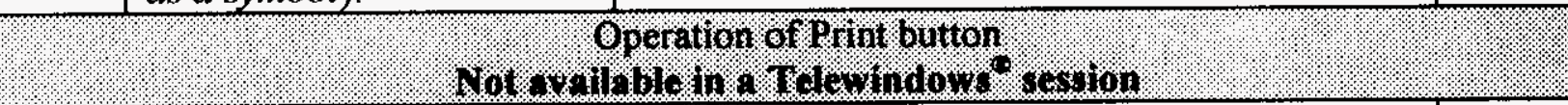 } \\
\hline 12. & $\begin{array}{l}\text { Click on the PRINT } \\
\text { SCREEN button. }\end{array}$ & $\begin{array}{l}\text { Verify that the User Selectable Trend } \\
\text { workspace prints. }\end{array}$ & \\
\hline \multicolumn{4}{|c|}{ Operation of the WIIVE buton . } \\
\hline 13. & $\begin{array}{l}\text { Click on the HIDE } \\
\text { WINDOW. }\end{array}$ & Verify that the workspace is hidden. & \\
\hline
\end{tabular}

\subsection{REPORTS}

\subsubsection{Suspect Sensor Report}

Prior to performing this test case set up sensors that have not reported a value within the current day. (Note: Emulator is required to get the quality status of sensors equal to good. Also need a large amount of sensors to display contimuous/discrete and SACS level sensors)

\begin{tabular}{|c|c|c|c|}
\hline Step & Perform & Expected Result & Initial \\
\hline 1. & $\begin{array}{l}\text { Select the Suspect Sensor } \\
\text { Report button from the } \\
\text { Reports Menu workspace. }\end{array}$ & $\begin{array}{l}\text { Verify the Suspect Sensor Report is displayed } \\
\text { with the following information: } \\
\text { - Hide (X) Button } \\
\text { - Minimize button ( } \\
\text { - Maximize button ( } A \text { ) } \\
\text { - Print button (P) } \\
\text { - Date of Report } \\
\text { - Number of Suspect Sensors }\end{array}$ & \\
\hline
\end{tabular}




\begin{tabular}{|c|c|c|c|}
\hline Step & Perform & Expected Result & Initial \\
\hline & & $\begin{array}{l}\text { - Sensor Insert Count (Signifies the number } \\
\text { of sensors displayed in report table.) } \\
\text { - Table Processing Status (i.e. Done) } \\
\text { - Include Continuous check box (defoult is } \\
\text { checked) } \\
\text { - Include Discrete check box (default is } \\
\text { unchecked) } \\
\text { - Include SACS Levels check box (default is } \\
\text { unchecked) } \\
\text { - Sort Report check box. (Sorted by TAG } \\
\text { NAME; default is unchecked) } \\
\text { - Update button } \\
\text { - Abort Report button } \\
\text { - Top of Table button (| } 4) \\
\text { - Previous page button (4) } \\
\text { - Next page button ( }) \\
\text { - End of Table button ( } \\
\text { - Report table containing the following } \\
\text { columns: } \\
\text { - NO (Signifies the line/row number) } \\
\text { - TAG_NAME } \\
\text { - LAST-GOOD-READING } \\
\text { - IO-STATION }\end{array}$ & \\
\hline 2. & $\begin{array}{l}\text { Click the Update button } \\
\text { Wait until Table } \\
\text { Processing Status displays } \\
\text { DONE. }\end{array}$ & $\begin{array}{l}\text { Verify the following: } \\
\text { - Report Table is updated } \\
\text { - Date of Report is updated. } \\
\text { - Sensor Insert Count is equal to the number of } \\
\text { sensor in the table. } \\
\text { - Number of Suspect Sensor is equal to the } \\
\text { Sensor Insert Count. } \\
\text { Note the Table Processing Status will change } \\
\text { from Done to Active back to Done. }\end{array}$ & \\
\hline 3. & $\begin{array}{l}\text { Click each combination of } \\
\text { the following check boxes. } \\
\text { - Include Continuous } \\
\text { - Include Discrete } \\
\text { Click the Update button. } \\
\text { Wait until Table }\end{array}$ & $\begin{array}{l}\text { Verify the following: } \\
\text { - The appropriate check box (s) is checked. } \\
\text { - Report Table is updated with the appropriate } \\
\text { data . } \\
\text { - Date of Report is updated. } \\
\text { - Sensor Insert Count is equal to the number of } \\
\text { sensor in the table. } \\
\text { - Number of Suspect Sensors is equal to the } \\
\text { Sensor Insert Count. }\end{array}$ & \\
\hline
\end{tabular}


HNF-3967, Rev. 4

\begin{tabular}{|c|c|c|c|}
\hline Step & Perform & Expected Result & Initial \\
\hline$\overline{3}$ & $\begin{array}{l}\text { Processing Status displays } \\
\text { DONE. }\end{array}$ & $\begin{array}{l}\text { Note the Table Processing Status will change } \\
\text { from Done to Active back to Done. }\end{array}$ & \\
\hline 4. & $\begin{array}{l}\text { Click the Sort check box so } \\
\text { the box is checked. } \\
\text { Click the Update button. } \\
\text { Wait until Table } \\
\text { Processing Status displays } \\
\text { DONE. }\end{array}$ & $\begin{array}{l}\text { Verify the following: } \\
\text { - Sort check box is checked. } \\
\text { - Report Table is updated and the data is } \\
\text { sorted by TAG_NAME. } \\
\text { Date of Report is updated } \\
\text { - Sensor Insert Count is equal to the number of } \\
\text { sensor in the table. } \\
\text { Number of Suspect Sensors is equal to the } \\
\text { Sensor Insert Count. } \\
\text { Note the Table Processing Status will change } \\
\text { from Done to Active back to Done. }\end{array}$ & \\
\hline 5. & $\begin{array}{l}\text { Click the Sort check box so } \\
\text { the box is unchecked. } \\
\text { Click the Update button. } \\
\text { Wait until Table } \\
\text { Processing Status displays } \\
\text { DONE. }\end{array}$ & $\begin{array}{l}\text { Verify the following: } \\
\text { - Sort check box is unchecked. } \\
\text { - Report Table is updated (Note the data may } \\
\text { or may not be sorted depending on how the } \\
\text { data was read in). } \\
\text { - Date of Report is updated } \\
\text { - Sensor Insert Count is equal to the number of } \\
\text { sensor in the table. } \\
\text { - Number of Suspect Sensors is equal to the } \\
\text { Sensor Insert Count. } \\
\text { Note the Table Processing Status will change } \\
\text { from Done to Active back to Done }\end{array}$ & \\
\hline 6. & $\begin{array}{l}\text { Click the Update button } \\
\text { immediately followed by } \\
\text { the Abort Report button. }\end{array}$ & $\begin{array}{l}\text { Verify the following: } \\
\text { - Date of Report is updated } \\
\text { - Sensor Insert Count is equal to the number of } \\
\text { sensor in the table. } \\
\text { - Number of Suspect Sensors is not equal to } \\
\text { the Sensor Insert Count. } \\
\text { - Table Processing Status changes to Abort } \\
\text { Note the Table Processing Status will change } \\
\text { from Done to Active to Abort }\end{array}$ & \\
\hline 7. & $\begin{array}{l}\text { Click on the Title block of } \\
\text { the report table. }\end{array}$ & $\begin{array}{l}\text { Verify the help workspace for this report is } \\
\text { displayed. }\end{array}$ & \\
\hline 8. & Click the Maximize button. & Verify the workspace is maximized. & \\
\hline
\end{tabular}


HNF-3967, Rev. 4

\begin{tabular}{|c|c|c|c|}
\hline Step & Perform & Expected Result & Initial \\
\hline 9. & Click the Minimize button & Verify the workspace is minimized & \\
\hline 10. & $\begin{array}{l}\text { Click on the Top of report } \\
\text { button }(\mid \varangle) \text {. }\end{array}$ & $\begin{array}{l}\text { Verify that the portion of the report displayed is } \\
\text { the first page in the report. (Note: Report may fit } \\
\text { on one page and therefore no change is seen.) }\end{array}$ & \\
\hline 11 . & $\begin{array}{l}\text { Click on the End of report } \\
\text { button }(\triangleright \mid) \text {. }\end{array}$ & $\begin{array}{l}\text { Verify the portion of the report displayed is the } \\
\text { last page in the report. (Note: Report may fit on } \\
\text { one page and therefore no change is seen.) }\end{array}$ & \\
\hline 12. & $\begin{array}{l}\text { Click the Previous page } \\
\text { button (४) }\end{array}$ & $\begin{array}{l}\text { Verify the portion of the report displayed is the } \\
\text { previous page. (Note: Report may fit on one } \\
\text { page and therefore no change is seen.) }\end{array}$ & \\
\hline 13. & $\begin{array}{l}\text { Click the Next page button } \\
(\triangleright) \text {. }\end{array}$ & $\begin{array}{l}\text { Verify the portion of the report displayed is the } \\
\text { next page. (Note: Report may fit on one page } \\
\text { and therefore no change is seen.) }\end{array}$ & \\
\hline 14. & $\begin{array}{l}\text { Click on the Print button } \\
\text { (P). (Note: Not functional } \\
\text { on the remote stations at } \\
\text { this time.) }\end{array}$ & $\begin{array}{l}\text { Verify the portion of the workspace displayed is } \\
\text { printed to the printer. }\end{array}$ & \\
\hline 15 . & $\begin{array}{l}\text { Click on the Hide button } \\
\text { (X). }\end{array}$ & port workspace is hidden. & \\
\hline
\end{tabular}

\subsubsection{Suspect 10-Station Report}

Prior to performing this test case set up IO stations that are not reporting.

\begin{tabular}{|c|c|c|c|}
\hline Step & Perform & Expected Result & Initial \\
\hline 1. & $\begin{array}{l}\text { Select the Suspect VOO- } \\
\text { Station Report button } \\
\text { from the Reports Menu } \\
\text { workspace. }\end{array}$ & 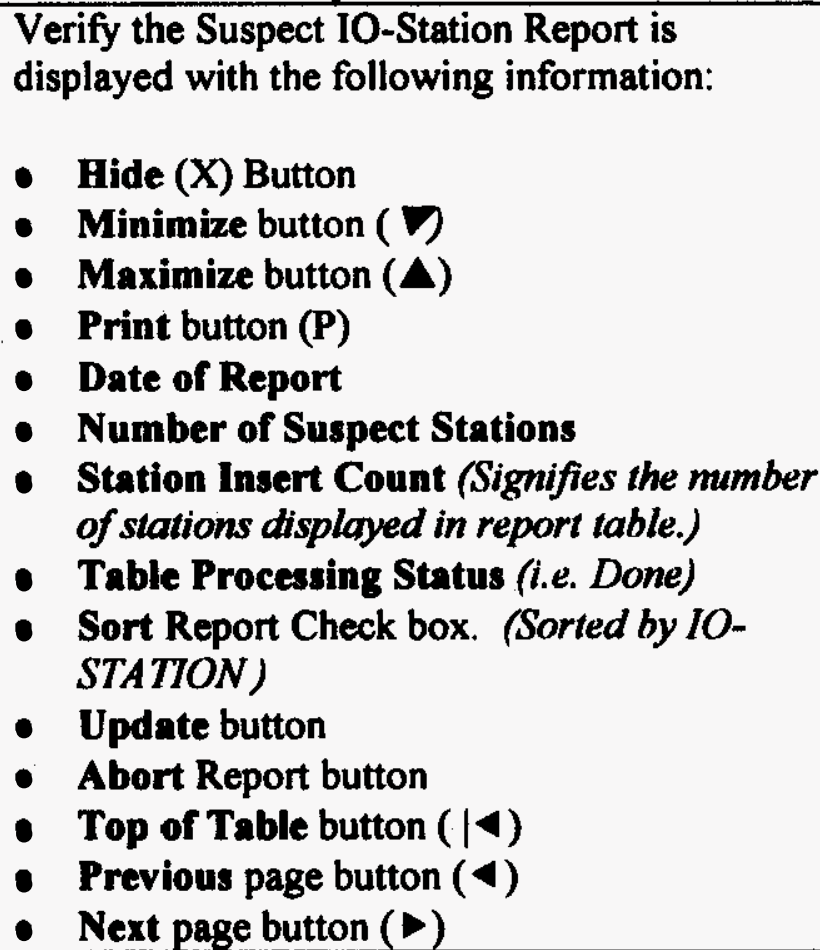 & \\
\hline
\end{tabular}


HNF-3967, Rev. 4

\begin{tabular}{|c|c|c|c|}
\hline Step & Perform & Expected Result & Initial \\
\hline & & $\begin{array}{l}\text { - End of Table button ( } 1 \text { ) } \\
\text { - Report table containing the following } \\
\text { columns: } \\
\text { - NO (Signifies the line/row number) } \\
\text { - IO-STATION } \\
\text { - EXPIRATION TIME } \\
\text { - POLLING-FREQ }\end{array}$ & \\
\hline 2. & $\begin{array}{l}\text { Click the Update button } \\
\text { Wait until Table } \\
\text { Processing Status displays } \\
\text { DONE. }\end{array}$ & $\begin{array}{l}\text { Verify the following: } \\
\text { - Report Table is updated } \\
\text { - Date of Report is updated. } \\
\text { - Station Insert Count is equal to the number } \\
\text { of station in the table. } \\
\text { - Number of Suspect Stations is equal to the } \\
\text { Station Insert Count. } \\
\text { Note the Table Processing Status will change } \\
\text { from Done to Active back to Done }\end{array}$ & \\
\hline 3. & $\begin{array}{l}\text { Click the Sort check box so } \\
\text { it is checked. } \\
\text { Click the Update button. } \\
\text { Wait until Table } \\
\text { Processing Status displays } \\
\text { DONE. }\end{array}$ & $\begin{array}{l}\text { Verify the following: } \\
\text { - Sort check box is checked. } \\
\text { - Report Table is updated and the data is } \\
\text { sorted by IO-STATION. } \\
\text { - Date of Report is updated } \\
\text { - Station Insert Count is equal to the number } \\
\text { of station in the table. } \\
\text { - Number of Suspect Stations is equal to the } \\
\text { Station Insert Count. } \\
\text { Note the Table Processing Status will change } \\
\text { from Done to Active back to Done }\end{array}$ & \\
\hline 4. & $\begin{array}{l}\text { Click the Sort check box so } \\
\text { it is unchecked. } \\
\text { Click the Update button. } \\
\text { Wait until Table } \\
\text { Processing Status displays. } \\
\text { DONE. }\end{array}$ & $\begin{array}{l}\text { Verify the following: } \\
\text { - Sort check box is unchecked. } \\
\text { - Report Table is updated (Note the data may } \\
\text { or maynot be sorted depending on how the } \\
\text { data was read in). } \\
\text { - Date of Report is updated } \\
\text { - Station Insert Count is equal to the number } \\
\text { of stations in the table. } \\
\text { - Number of Suspect Stations is equal to the } \\
\text { Station Insert Count. } \\
\text { Note the Table Processing Status will change }\end{array}$ & \\
\hline
\end{tabular}


HNF-3967, Rev. 4

\begin{tabular}{|c|c|c|c|}
\hline Step & Perform & Expected Result & Initial \\
\hline & & from Done to Active back to Done & \\
\hline 5. & $\begin{array}{l}\text { Click the Update button } \\
\text { immediately followed by } \\
\text { the Abort Report. }\end{array}$ & $\begin{array}{l}\text { Verify the following: } \\
\text { - Date of Report is updated } \\
\text { - Table Processing Status changes to Abort } \\
\text { - Station Insert Count is equal to the number } \\
\text { of station in the table. } \\
\text { - Number of Suspect Stations is not equal to } \\
\text { the Sensor Insert Count. } \\
\text { Note the Table Processing Status will change } \\
\text { from Done to Active to Abort }\end{array}$ & \\
\hline 6 . & $\begin{array}{l}\text { Click on the Title block of } \\
\text { the report table. }\end{array}$ & $\begin{array}{l}\text { Verify the help workspace for this report is } \\
\text { displayed. }\end{array}$ & \\
\hline 7. & Click the Maximize button. & Verify the workspace is maximized. & \\
\hline 8. & Click the Minimize button & Verify the workspace is minimized & \\
\hline 9. & $\begin{array}{l}\text { Click on the Top of report } \\
\text { button }(\mid \triangleleft) \text {. }\end{array}$ & $\begin{array}{l}\text { Verify that the portion of the report displayed is } \\
\text { the first page in the report. (Note: Report may fit } \\
\text { on one page and therefore no change is seen.) }\end{array}$ & \\
\hline 10. & $\begin{array}{l}\text { Click on the End of report } \\
\text { button }(\bullet \mid) \text {. }\end{array}$ & $\begin{array}{l}\text { Verify the portion of the report displayed is the } \\
\text { last page in the report. (Note: Report may fit on } \\
\text { one page and therefore no change is seen.) }\end{array}$ & \\
\hline 11. & $\begin{array}{l}\text { Click the Previous page } \\
\text { button }(\triangleleft)\end{array}$ & $\begin{array}{l}\text { Verify the portion of the report displayed is the } \\
\text { previous page. (Note: Report may fit on one } \\
\text { page and therefore no change is seen.) }\end{array}$ & \\
\hline 12 . & $\begin{array}{l}\text { Click the Next page } \\
\text { button }(\triangleright) \text {. }\end{array}$ & $\begin{array}{l}\text { Verify the portion of the report displayed is the } \\
\text { next page. (Note: Report may fit on one page } \\
\text { and therefore no change is seen.) }\end{array}$ & \\
\hline 13. & $\begin{array}{l}\text { Click on the Print button } \\
\text { (P). Note: Not functional } \\
\text { on the remote stations at } \\
\text { this time.) }\end{array}$ & $\begin{array}{l}\text { Verify the portion of the workspace displayed is } \\
\text { printed to the printer. }\end{array}$ & \\
\hline 14. & Click on a row in the table. & 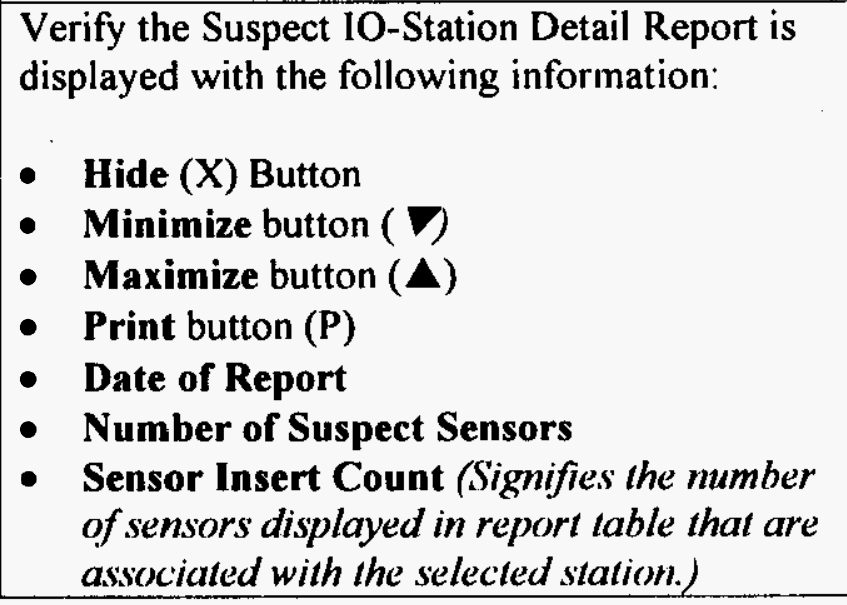 & \\
\hline
\end{tabular}




\begin{tabular}{|c|c|c|c|}
\hline Step & Perform & Expected Result & Initial \\
\hline & & $\begin{array}{l}\text { - Table Processing Status (i.e. Done) } \\
\text { - Sort Report Check box. (Sorted by IO- } \\
\text { STATION) } \\
\text { - Update button } \\
\text { - Abort Report button } \\
\text { - Top of Table button ( | ) } \\
\text { - Previous page button ( } 4) \\
\text { - Next page button ( }) \\
\text { - End of Table button ( } \\
\text { - Report table containing the following } \\
\text { columns: } \\
\text { - NO (Signifies the line/row number) } \\
\text { - TAG NAME } \\
\text { - LAST-GOOD-READING } \\
\text { - IO-STATION } \\
\text { - } \\
\text { Note: The Top of Table, Previous page, Next } \\
\text { Page and End of Table are included for future } \\
\text { use. There currently is no station that has more } \\
\text { than 25 (Table Size) sensors connected to it. }\end{array}$ & \\
\hline 15. & $\begin{array}{l}\text { Click the Update button } \\
\text { Wait until Table } \\
\text { Processing Status displays } \\
\text { DONE. }\end{array}$ & $\begin{array}{l}\text { Verify the following: } \\
\text { - Report Table is updated } \\
\text { - Date of Report is updated. } \\
\text { - Sensor Insert Count is equal to the number of } \\
\text { sensors in the table. } \\
\text { - Number of Sensors is equal to the Sensor } \\
\text { Insert Count. } \\
\text { Note the Table Processing Status will change } \\
\text { from Done to Active back to Done }\end{array}$ & \\
\hline 16. & $\begin{array}{l}\text { Click the Sort check box so } \\
\text { it is checked. } \\
\text { Click the Update button. } \\
\text { Wait until Table } \\
\text { Processing Status displays } \\
\text { DONE. }\end{array}$ & $\begin{array}{l}\text { Verify the following: } \\
\text { - Sort check box is checked. } \\
\text { - Report Table is updated and the data is } \\
\text { sorted by TAG_NAME. } \\
\text { - Date of Report is updated } \\
\text { - Sensor Insert Count is equal to the number of } \\
\text { sensor in the table. } \\
\text { - Number of Suspect Sensors is equal to the } \\
\text { Sensor Insert Count. } \\
\text { Note the Table Processing Status will change } \\
\text { from Done to Active back to Done }\end{array}$ & \\
\hline 17. & Click the Sort check box so & Verify the following: & \\
\hline
\end{tabular}


HNF-3967, Rev. 4

\begin{tabular}{|c|c|c|c|}
\hline Step & Perform & Expected Result & Initial \\
\hline & $\begin{array}{l}\text { it is unchecked. } \\
\text { Click the Update button. } \\
\text { Wait until Table } \\
\text { Processing Status displays } \\
\text { DONE. }\end{array}$ & $\begin{array}{l}\text { - Sort check box is unchecked. } \\
\text { - Report Table is updated Note the data may } \\
\text { or may not be sorted depending on how the } \\
\text { data was read in). } \\
\text { - Date of Report is updated } \\
\text { - Sensor Insert Count is equal to the number of } \\
\text { stations in the table. } \\
\text { - Number of Suspect Sensors is equal to the } \\
\text { Station Insert Count. } \\
\text { Note the Table Processing Status will change } \\
\text { from Done to Active back to Done }\end{array}$ & \\
\hline 18. & $\begin{array}{l}\text { Click the Update button } \\
\text { immediately followed by } \\
\text { the Abort Report. }\end{array}$ & $\begin{array}{l}\text { Verify the following: } \\
\text { - Date of Report is updated } \\
\text { - Sable Processing Status changes to Abort } \\
\text { of station in the table. } \\
\text { - Number of Suspect Sensors is not equal to } \\
\text { the Sensor Insert Count. } \\
\text { Note the Table Processing Status will change } \\
\text { from Done to Active to Abort }\end{array}$ & \\
\hline 19. & Click the Maximize button. & Verify the workspace is maximized. & \\
\hline 20. & Click the Minimize button & Verify the workspace is minimized & \\
\hline 21. & $\begin{array}{l}\text { Click on the Print button } \\
\text { (P). (Note: Not functional } \\
\text { on the remote stations at } \\
\text { this time.) }\end{array}$ & $\begin{array}{l}\text { Verify the portion of the workspace displayed is } \\
\text { printed to the printer. }\end{array}$ & \\
\hline 22. & $\begin{array}{l}\text { Click on the Hide }(\mathrm{X}) \\
\text { button on the Suspect IO- } \\
\text { Station Detail Report } \\
\text { workspace. }\end{array}$ & Verify the report workspace is hidden. & \\
\hline 23. & $\begin{array}{l}\text { Click on the Hide }(\mathrm{X}) \\
\text { button on the Suspect IO- } \\
\text { Station Report workspace. }\end{array}$ & Verify the report workspace is hidden. & \\
\hline
\end{tabular}




\subsubsection{Unknown Sensor Report}

Prior to performing this test case set the quality status of a few sensors to unknown.

\begin{tabular}{|c|c|c|c|}
\hline Step & Perform & Expected Result & Initial \\
\hline 24. & $\begin{array}{l}\text { Select the Unknown } \\
\text { Sensor Report button } \\
\text { from the Reports Menu } \\
\text { workspace. }\end{array}$ & 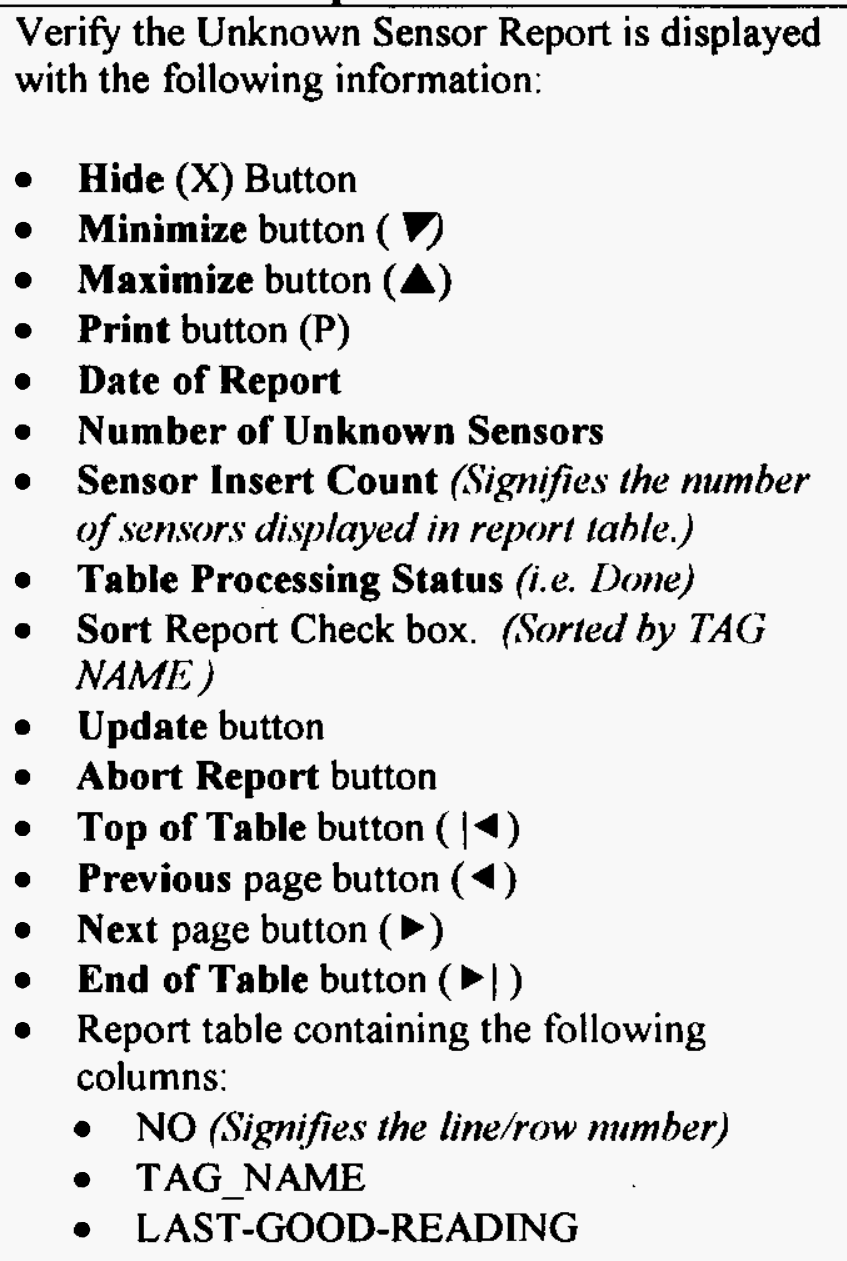 & \\
\hline 25. & $\begin{array}{l}\text { Click the Update button } \\
\text { Wait until Table } \\
\text { Processing Status displays } \\
\text { DONE. }\end{array}$ & $\begin{array}{l}\text { Verify the following: } \\
\text { - Report Table is updated } \\
\text { - Date of Report is updated. }\end{array}$ & \\
\hline 26. & $\begin{array}{l}\text { Click the Sort check box so } \\
\text { it is checked. } \\
\text { Click the Update button. } \\
\text { Wait until Table } \\
\text { Processing Status displays } \\
\text { DONE. }\end{array}$ & $\begin{array}{l}\text { Verify the following: } \\
\text { - Sort check box is checked. } \\
\text { - Report Table is updated and the data is } \\
\text { sorted by TAG_NAME. } \\
\text { - Date of Report is updated } \\
\text { - Sensor Insert Count is equal to the number of } \\
\text { sensor in the table. }\end{array}$ & \\
\hline
\end{tabular}


HNF-3967, Rev. 4

\begin{tabular}{|c|c|c|c|}
\hline Step & Perform & Expected Result & Initial \\
\hline & & $\begin{array}{l}\text { - Number of Sensor is equal to the Sensor } \\
\text { Insert Count. } \\
\text { Note the Table Processing Status will change } \\
\text { from Done to Active back to Done }\end{array}$ & \\
\hline 27. & $\begin{array}{l}\text { Click the Sort check box so } \\
\text { it is unchecked. } \\
\text { Click the Update button. } \\
\text { Wait until Table } \\
\text { Processing Status displays } \\
\text { DONE. }\end{array}$ & $\begin{array}{l}\text { Verify the following: } \\
\text { - Sort check box is unchecked. } \\
\text { - Report Table is updated (Note the data may } \\
\text { or maynot be sorted depending on how the } \\
\text { data was read in). } \\
\text { - Date of Report is updated } \\
\text { - Sensor Insert Count is equal to the number of } \\
\text { sensor in the table. } \\
\text { - Number of Sensor is equal to the Sensor } \\
\text { Insert Count. } \\
\text { Note the Table Processing Status will change } \\
\text { from Done to Active back to Done }\end{array}$ & \\
\hline 28. & $\begin{array}{l}\text { Click the Update button } \\
\text { immediately followed by } \\
\text { the Abort Report. }\end{array}$ & $\begin{array}{l}\text { Verify the following: } \\
\text { - Date of Report is updated } \\
\text { - Table Processing Status changes to Abort } \\
\text { Sensor Insert Count is equal to the number of } \\
\text { - Number of Sensor is not equal to the Sensor } \\
\text { Insert Count. } \\
\text { Note the Table Processing Status will change } \\
\text { from Done to Active to Abort }\end{array}$ & \\
\hline 29. & $\begin{array}{l}\text { Click on the Title block of } \\
\text { the report table. }\end{array}$ & $\begin{array}{l}\text { Verify the help workspace for this report is } \\
\text { displayed. }\end{array}$ & \\
\hline 30. & Click the Maximize button. & Verify the workspace is maximized. & \\
\hline 31. & Click the Minimize button & Verify the workspace is minimized & \\
\hline 32. & $\begin{array}{l}\text { Click on the Top of report } \\
\text { button }(\mid \varangle) \text {. }\end{array}$ & $\begin{array}{l}\text { Verify that the portion of the report displayed is } \\
\text { the first page in the report. (Note: Report may fit } \\
\text { on one page and therefore no change is seen.) }\end{array}$ & \\
\hline 33. & $\begin{array}{l}\text { Click on the End of report } \\
\text { button }(\triangleright \mid) \text {. }\end{array}$ & $\begin{array}{l}\text { Verify the portion of the report displayed is the } \\
\text { last page in the report. (Note: Report may fit on } \\
\text { one page and therefore no change is seen.) }\end{array}$ & \\
\hline 34. & $\begin{array}{l}\text { Click the Previous page } \\
\text { button ( } \triangleleft)\end{array}$ & $\begin{array}{l}\text { Verify the portion of the report displayed is the } \\
\text { previous page. (Note: Report may fit on one } \\
\text { page and therefore no change is seen.) }\end{array}$ & \\
\hline 35 . & Click the Next page & Verify the portion of the report displayed is the & \\
\hline
\end{tabular}


HNF-3967, Rev. 4

\begin{tabular}{|c|c|c|c|}
\hline Step & Perform & Expected Result & Initial \\
\hline & button( $(-)$ & $\begin{array}{l}\text { next page. (Note: Report may fit on one page } \\
\text { and therefore no change is seen.) }\end{array}$ & \\
\hline 36. & $\begin{array}{l}\text { Click on the Print button } \\
\text { (P). Note: Not functional } \\
\text { on the remote stations at } \\
\text { this time.) }\end{array}$ & $\begin{array}{l}\text { Verify the portion of the workspace displayed is } \\
\text { printed to the printer. }\end{array}$ & \\
\hline 37. & $\begin{array}{l}\text { Click on the Hide button } \\
(\mathrm{X}) \text {. }\end{array}$ & Verify the report workspace is hidden. & \\
\hline
\end{tabular}

\subsubsection{ENRAF Non-Operating Mode Report}

\begin{tabular}{|c|c|c|c|}
\hline Step & Perform & Expected Result & $\underset{1}{\text { Initin }}$ \\
\hline 1 & $\begin{array}{l}\text { Select the ENRAF Non- } \\
\text { Operating Mode } \\
\text { Report button from the } \\
\text { Reports Menu } \\
\text { workspace. }\end{array}$ & 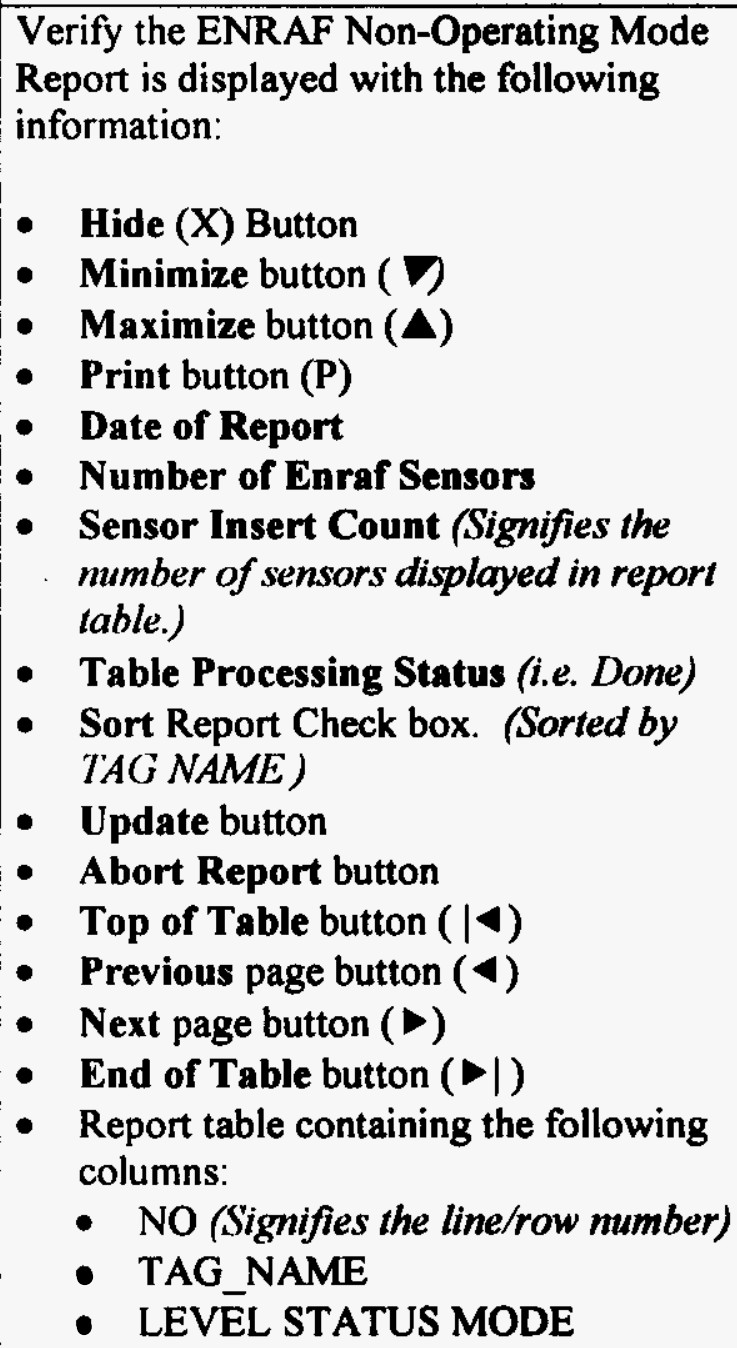 & \\
\hline 2. & $\begin{array}{l}\text { Using the ENRAF } \\
\text { emulator generate }\end{array}$ & $\begin{array}{l}\text { Verify the following: } \\
\text { - Report Table is updated with the }\end{array}$ & \\
\hline
\end{tabular}


HNF-3967, Rev. 4

\begin{tabular}{|c|c|c|c|}
\hline Step & Perform & Expected Result & $\begin{array}{c}\text { Initia } \\
\end{array}$ \\
\hline & $\begin{array}{l}\text { ENRAF messages that } \\
\text { have a level status other } \\
\text { than "_-" } \\
\text { Click the Update button } \\
\text { Wait until Table } \\
\text { Processing Status } \\
\text { displays DONE. }\end{array}$ & $\begin{array}{ll} & \text { appropriate sensors } \\
\text { - } & \text { Date of Report is updated. } \\
\text { - Number of Enraf Sensors is updated } \\
\text { - Sensor Insert Count }\end{array}$ & \\
\hline 3. & $\begin{array}{l}\text { Click the Sort check box } \\
\text { so it is checked. } \\
\text { Click the Update } \\
\text { button. } \\
\text { Wait until Table } \\
\text { Processing Status } \\
\text { displays DONE. }\end{array}$ & $\begin{array}{l}\text { Verify the following: } \\
\text { - Sort check box is checked. } \\
\text { - Report Table is updated and the data is } \\
\text { sorted by TAG_NAME. } \\
\text { - Date of Report is updated } \\
\text { - Sensor Insert Count is equal to the } \\
\text { number of sensor in the table. } \\
\text { - Number of Enraf Sensors is equal to the } \\
\text { Sensor Insert Count. } \\
\text { Note the Table Processing Status will } \\
\text { change from Done to Active back to Done }\end{array}$ & \\
\hline 4. & $\begin{array}{l}\text { Click the Sort check box } \\
\text { so it is unchecked. } \\
\text { Click the Update } \\
\text { button. } \\
\text { Wait until Table } \\
\text { Processing Status } \\
\text { displays DONE. }\end{array}$ & $\begin{array}{l}\text { Verify the following: } \\
\text { - Sort check box is unchecked. } \\
\text { - Report Table is updated (Note the data } \\
\text { may or may not be sorted depending on } \\
\text { how the data was read in). } \\
\text { - Date of Report is updated } \\
\text { - Sensor Insert Count is equal to the } \\
\text { number of sensor in the table. } \\
\text { - Number of Enraf Sensor is equal to the } \\
\text { Sensor Insert Count. } \\
\text { Note the Table Processing Status will } \\
\text { change from Done to Active back to Done }\end{array}$ & \\
\hline 5. & $\begin{array}{l}\text { Click the Update button } \\
\text { immediately followed } \\
\text { by the Abort Report. }\end{array}$ & $\begin{array}{l}\text { Verify the following: } \\
\text { - Date of Report is updated } \\
\text { - Table Processing Status changes to } \\
\text { Abort } \\
\text { - Sensor Insert Count is equal to the } \\
\text { number of sensor in the table. }\end{array}$ & \\
\hline
\end{tabular}


HNF-3967, Rev. 4

\begin{tabular}{|c|c|c|c|}
\hline Step & Perform & Expected Result & Initia \\
\hline & & $\begin{array}{l}\text { Number of Enraf Sensors is not equal to } \\
\text { the Sensor Insert Count. } \\
\text { Note the Table Processing Status will } \\
\text { change from Done to Active to Abort }\end{array}$ & \\
\hline 6. & $\begin{array}{l}\text { Using the ENRAF } \\
\text { emulator generate } \\
\text { ENRAF messages that } \\
\text { have a level status of "- } \\
\text { " } \\
\text { Click the Update button } \\
\text { Wait until Table } \\
\text { Processing Status } \\
\text { displays DONE. }\end{array}$ & $\begin{array}{l}\text { Verify the following: } \\
\text { - Report Table is updated with the } \\
\text { appropriate sensors } \\
\text { - Date of Report is updated. } \\
\text { - Number of Enraf Sensors is updated } \\
\text { - Sensor Insert Count }\end{array}$ & \\
\hline 7. & $\begin{array}{l}\text { Click on the Title block } \\
\text { of the report table. }\end{array}$ & $\begin{array}{l}\text { Verify the help workspace for this report is } \\
\text { displayed. }\end{array}$ & \\
\hline 8. & $\begin{array}{l}\text { Click the Maximize } \\
\text { button. }\end{array}$ & Verify the workspace is maximized. & \\
\hline 9. & $\begin{array}{l}\text { Click the Minimize } \\
\text { button }\end{array}$ & Verify the workspace is minimized & \\
\hline 10. & $\begin{array}{l}\text { Click on the Top of } \\
\text { report button }(\end{array}$ & $\begin{array}{l}\text { Verify that the portion of the report } \\
\text { displayed is the first page in the report. } \\
\text { Note: Report may fit on one page and } \\
\text { therefore no change is seen.) }\end{array}$ & \\
\hline 11. & $\begin{array}{l}\text { Click on the End of } \\
\text { report button }(\triangleright \mid) \text {. }\end{array}$ & $\begin{array}{l}\text { Verify the portion of the report displayed is } \\
\text { the last page in the report. Note: Report } \\
\text { may fit on one page and therefore no } \\
\text { change is seen.) }\end{array}$ & \\
\hline 12. & $\begin{array}{l}\text { Click the Previous page } \\
\text { button }(\triangleleft)\end{array}$ & $\begin{array}{l}\text { Verify the portion of the report displayed is } \\
\text { the previous page. (Note: Report may fit on } \\
\text { one page and therefore no change is seen.) }\end{array}$ & \\
\hline 13. & $\begin{array}{l}\text { Click the Next page } \\
\text { button }(\triangleright) \text {. }\end{array}$ & $\begin{array}{l}\text { Verify the portion of the report displayed is } \\
\text { the next page. (Note: Report may fit on one } \\
\text { page and therefore no change is seen.) }\end{array}$ & \\
\hline 14. & $\begin{array}{l}\text { Click on the Print } \\
\text { button (P). (Note: Not } \\
\text { functional on the remote } \\
\text { stations at this time.) }\end{array}$ & $\begin{array}{l}\text { Verify the portion of the workspace } \\
\text { displayed is printed to the printer. }\end{array}$ & \\
\hline 15. & $\begin{array}{l}\text { Click on the Hide button } \\
(\mathrm{X}) \text {. }\end{array}$ & Verify the report workspace is hidden. & \\
\hline
\end{tabular}


HNF-3967, Rev. 4

\subsubsection{Sensor Disable Alarm Report}

\begin{tabular}{|c|c|c|c|}
\hline Step & Perform & Expected Result & $\begin{array}{c}\text { Initia } \\
1\end{array}$ \\
\hline 1. & $\begin{array}{l}\text { Select the Sensor } \\
\text { Disable Alarm Report } \\
\text { button from the Reports } \\
\text { Menu workspace. }\end{array}$ & 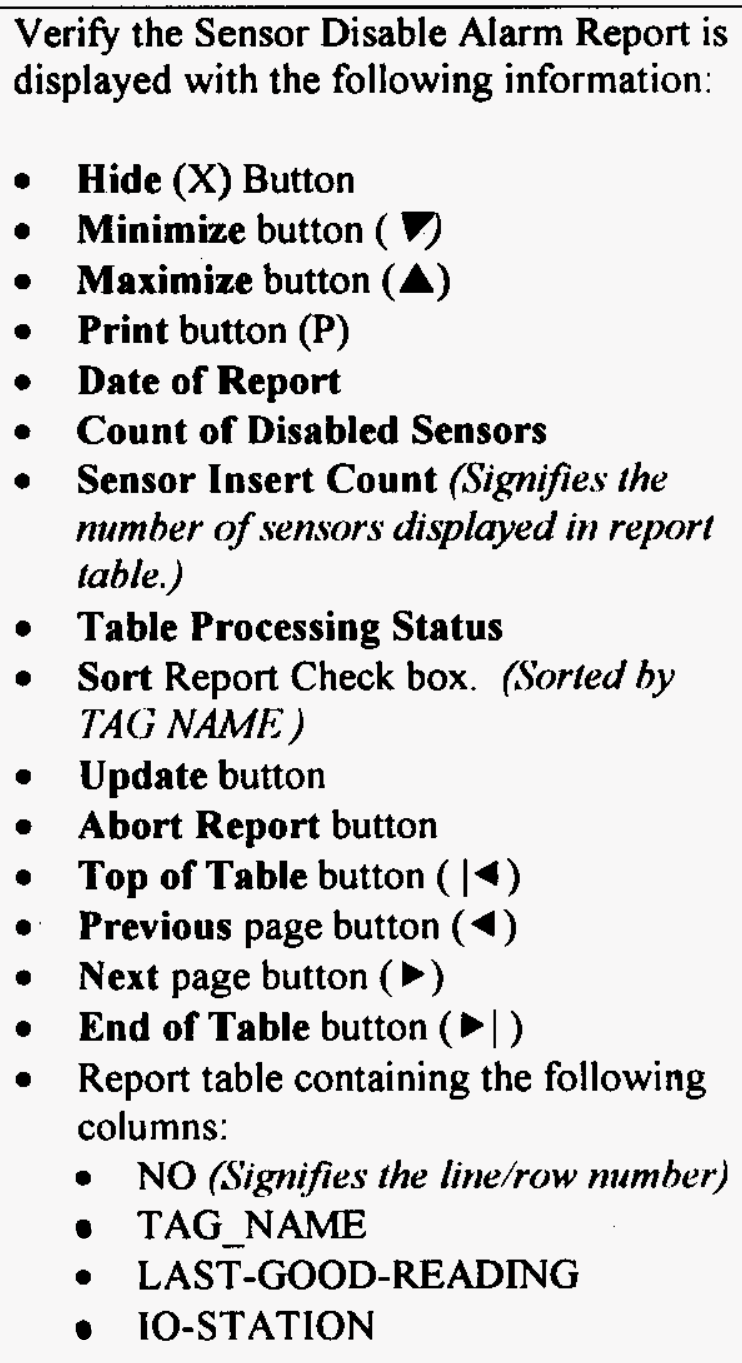 & \\
\hline 2. & $\begin{array}{l}\text { Disable Alarm } \\
\text { processing for one or } \\
\text { more sensor(s). } \\
\text { Click the Update button } \\
\text { Wait until Table } \\
\text { Processing Status } \\
\text { displays DONE. }\end{array}$ & $\begin{array}{l}\text { Verify the following: } \\
\text { - Report Table is updated with the } \\
\text { appropriate sensors. } \\
\text { - Date of Report is updated. }\end{array}$ & \\
\hline 3. & $\begin{array}{l}\text { Click on a row in the } \\
\text { Report Table that }\end{array}$ & $\begin{array}{l}\text { Verify the tank workspace associated with } \\
\text { the chosen test sensor is displaved. }\end{array}$ & \\
\hline
\end{tabular}


HNF-3967, Rev. 4

\begin{tabular}{|c|c|c|c|}
\hline Step & Perform & Expected Result & $\begin{array}{c}\text { Initia } \\
\mid\end{array}$ \\
\hline & contains a sensor record. & $\begin{array}{l}\text { Note: Hide the tank workspace when } \\
\text { through with this test. }\end{array}$ & \\
\hline 4. & $\begin{array}{l}\text { Click the Sort check box } \\
\text { so it is checked. } \\
\text { Click the Update } \\
\text { button. } \\
\text { Wait until Table } \\
\text { Processing Status } \\
\text { displays DONE. }\end{array}$ & $\begin{array}{l}\text { Verify the following: } \\
\text { - Sort check box is checked. } \\
\text { - Report Table is updated and the data is } \\
\text { sorted by TAG_NAME. } \\
\text { - Date of Report is updated } \\
\text { - Sensor Insert Count is equal to the } \\
\text { number of sensor in the table. } \\
\text { - Number of Disabled Sensors is equal to } \\
\text { the Sensor Insert Count. } \\
\text { Note the Table Processing Status will } \\
\text { change from Done to Active back to Done }\end{array}$ & \\
\hline 5. & $\begin{array}{l}\text { Click the Sort check box } \\
\text { so it is unchecked. } \\
\text { Click the Update } \\
\text { button. } \\
\text { Wait until Table } \\
\text { Processing Status } \\
\text { displays DONE. }\end{array}$ & $\begin{array}{l}\text { Verify the following: } \\
\text { - Sort check box is unchecked. } \\
\text { Report Table is updated (Note the data } \\
\text { may or may not be sorted depending on } \\
\text { how the data was read in). } \\
\text { Date of Report is updated } \\
\text { - Sensor Insert Count is equal to the } \\
\text { number of sensor in the table. } \\
\text { Number of Disabled Sensors is equal to } \\
\text { the Sensor Insert Count. } \\
\text { Note the Table Processing Status will } \\
\text { change from Done to Active back to Done }\end{array}$ & \\
\hline 6. & $\begin{array}{l}\text { Click the Update button } \\
\text { immediately followed } \\
\text { by the Abort Report. }\end{array}$ & $\begin{array}{l}\text { Verify the following: } \\
\text { - Date of Report is updated } \\
\text { Table Processing Status changes to } \\
\text { Abort } \\
\text { Sensor Insert Count is equal to the } \\
\text { number of sensor in the table. } \\
\text { Number of Disabled Sensors is not } \\
\text { equal to the Sensor Insert Count. } \\
\text { Note the Table Processing Status will } \\
\text { change from Done to Active to Abort }\end{array}$ & \\
\hline 7. & Enable Alarm & Verify the following: & \\
\hline
\end{tabular}


HNF-3967, Rev. 4

\begin{tabular}{|c|c|c|c|}
\hline Step & Perform & Expected Result & $\begin{array}{c}\text { Initia } \\
1\end{array}$ \\
\hline & $\begin{array}{l}\text { processing for one or } \\
\text { more sensors that was } \\
\text { disabled previously. } \\
\text { Click the Update button } \\
\text { Wait until Table } \\
\text { Processing Status } \\
\text { displays DONE. }\end{array}$ & $\begin{array}{l}\text { - Report Table is updated with the } \\
\text { appropriate sensors } \\
\text { - Date of Report is updated. }\end{array}$ & \\
\hline 8. & $\begin{array}{l}\text { Click on the Title block } \\
\text { of the report table. }\end{array}$ & $\begin{array}{l}\text { Verify the help workspace for this report is } \\
\text { displayed. }\end{array}$ & \\
\hline 9. & $\begin{array}{l}\text { Click the Maximize } \\
\text { button. }\end{array}$ & Verify the workspace is maximized. & \\
\hline 10. & $\begin{array}{l}\text { Click the Minimize } \\
\text { button }\end{array}$ & Verify the workspace is minimized & \\
\hline 11. & $\begin{array}{l}\text { Click on the Top of } \\
\text { report button }(\mid \varangle) \text {. }\end{array}$ & $\begin{array}{l}\text { Verify that the portion of the report } \\
\text { displayed is the first page in the report. } \\
\text { Note: Report may fil on one page and } \\
\text { therefore no change is seen.) }\end{array}$ & \\
\hline 12. & $\begin{array}{l}\text { Click on the End of } \\
\text { report button }(\triangleright \mid)\end{array}$ & $\begin{array}{l}\text { Verify the portion of the report displayed is } \\
\text { the last page in the report. (Note: Report } \\
\text { may fit on one page and therefore no } \\
\text { change is seen.) }\end{array}$ & \\
\hline 13. & $\begin{array}{l}\text { Click the Previous page } \\
\text { button }(\triangleleft)\end{array}$ & $\begin{array}{l}\text { Verify the portion of the report displayed is } \\
\text { the previous page. (Note: Report may fit on } \\
\text { one page and therefore no change is seen.) }\end{array}$ & \\
\hline 14. & $\begin{array}{l}\text { Click the Next page } \\
\text { button }(\triangleright) \text {. }\end{array}$ & $\begin{array}{l}\text { Verify the portion of the report displayed is } \\
\text { the next page. (Note: Report may fit on one } \\
\text { page and therefore no change is seen.) }\end{array}$ & \\
\hline 15. & $\begin{array}{l}\text { Click on the Print } \\
\text { button (P). (Note: Not } \\
\text { functional on the remote } \\
\text { stations at this time.) }\end{array}$ & $\begin{array}{l}\text { Verify the portion of the workspace } \\
\text { displayed is printed to the printer. }\end{array}$ & \\
\hline 16. & $\begin{array}{l}\text { Click on the Hide button } \\
\text { (X). }\end{array}$ & Verify the report workspace is hidden. & \\
\hline
\end{tabular}

\subsubsection{Sensor Enabled Test Report}

\begin{tabular}{|l|l|l|c|}
\hline Step & \multicolumn{1}{|c|}{ Perform } & \multicolumn{1}{|c|}{ Expected Result } & $\begin{array}{c}\text { Initia } \\
\text { I }\end{array}$ \\
\hline 1. & $\begin{array}{l}\text { Select the Sensor } \\
\text { Enabled Test Report } \\
\text { button from the Reports }\end{array}$ & $\begin{array}{l}\text { Verify the Sensor Enabled Test Report is } \\
\text { displayed with the following information: }\end{array}$ & \\
\hline
\end{tabular}


HNF-3967, Rev. 4

\begin{tabular}{|c|c|c|c|}
\hline Step & Perform & Expected Result & $\begin{array}{c}\text { Initia } \\
1\end{array}$ \\
\hline & Menu workspace. & 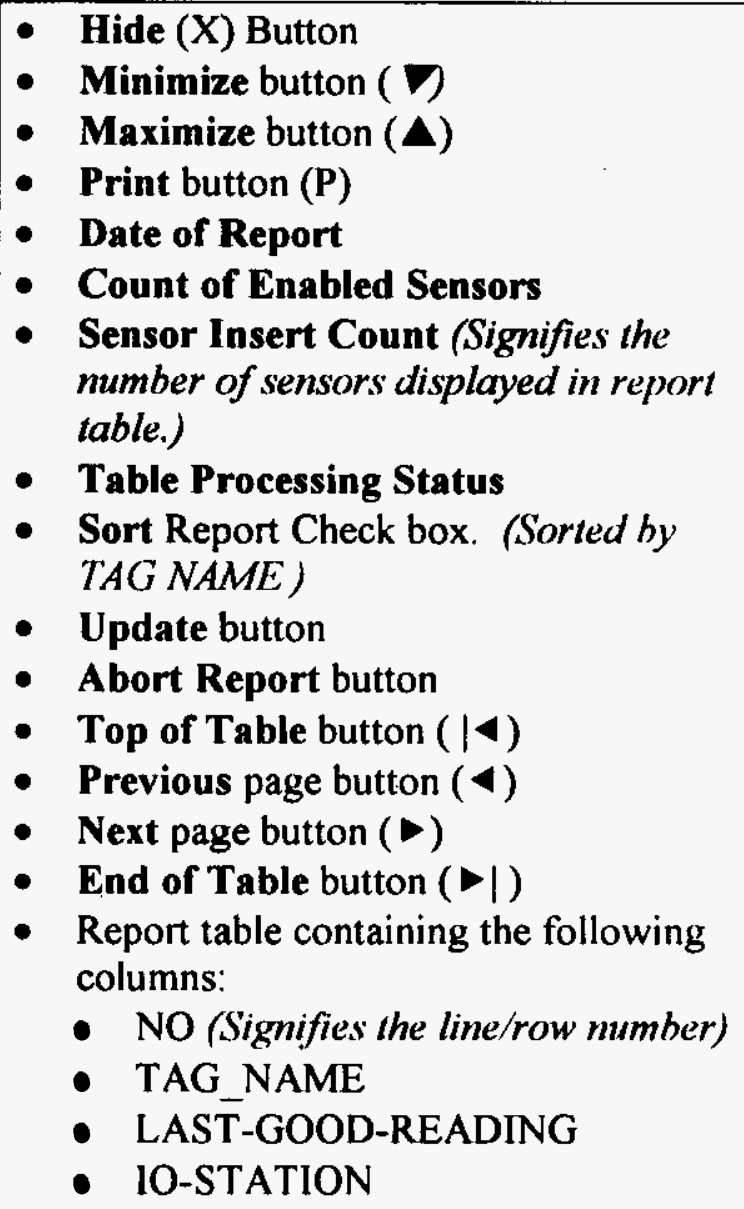 & \\
\hline 2. & $\begin{array}{l}\text { Place a one or more } \\
\text { sensor(s) in the test } \\
\text { mode. } \\
\text { Click the Update button } \\
\text { Wait until Table } \\
\text { Processing Status } \\
\text { displays DONE. }\end{array}$ & $\begin{array}{l}\text { Verify the following: } \\
\text { Report Table is updated with the } \\
\text { appropriate sensors } \\
\text { - Date of Report is updated. }\end{array}$ & \\
\hline 3. & $\begin{array}{l}\text { Click on a row in the } \\
\text { Report Table that } \\
\text { contains a test sensor } \\
\text { record. }\end{array}$ & $\begin{array}{l}\text { Verify the tank workspace associated with } \\
\text { the chosen test sensor is displayed. } \\
\text { Note: Hide the tank workspace when } \\
\text { through with this test. }\end{array}$ & \\
\hline 4. & $\begin{array}{l}\text { Click the Sort check box } \\
\text { so it is checked. } \\
\text { Click the Update }\end{array}$ & $\begin{array}{l}\text { Verify the following: } \\
\text { - Sort check box is checked. } \\
\text { - Report Table is updated and the data is }\end{array}$ & \\
\hline
\end{tabular}


HNF-3967, Rev. 4

\begin{tabular}{|c|c|c|c|}
\hline Step & Perform & Expected Result & Initia \\
\hline & $\begin{array}{l}\text { button. } \\
\text { Wait until Table } \\
\text { Processing Status } \\
\text { displays DONE. }\end{array}$ & $\begin{array}{l}\text { sorted by TAG_NAME. } \\
\text { - Date of Report is updated } \\
\text { - Sensor Insert Count is equal to the } \\
\text { number of sensor in the table. } \\
\text { - Number of Enabled Sensors is equal to } \\
\text { the Sensor Insert Count. } \\
\text { Note the Table Processing Status will } \\
\text { change from Done to Active back to Done }\end{array}$ & \\
\hline 5. & $\begin{array}{l}\text { Click the Sort check box } \\
\text { so it is unchecked. } \\
\text { Click the Update } \\
\text { button. } \\
\text { Wait until Table } \\
\text { Processing Status } \\
\text { displays DONE. }\end{array}$ & $\begin{array}{l}\text { Verify the following: } \\
\text { - Sort check box is unchecked. } \\
\text { - Report Table is updated (Note the data } \\
\text { may or may not be sorted depending on } \\
\text { how the data was read in). } \\
\text { - Date of Report is updated } \\
\text { - Sensor Insert Count is equal to the } \\
\text { number of sensor in the table. } \\
\text { - Number of Enabled Sensors is equal to } \\
\text { the Sensor Insert Count. } \\
\text { Note the Table Processing Status will } \\
\text { change from Done to Active back to Done }\end{array}$ & \\
\hline 6. & $\begin{array}{l}\text { Click the Update button } \\
\text { immediately followed } \\
\text { by the Abort Report. }\end{array}$ & $\begin{array}{l}\text { Verify the following: } \\
\text { Date of Report is updated } \\
\text { Table Processing Status changes to } \\
\text { Abort } \\
\text { - Sensor Insert Count is equal to the } \\
\text { number of sensor in the table. } \\
\text { - Number of Enabled Sensors is not equal } \\
\text { to the Sensor Insert Count. } \\
\text { Note the Table Processing Status will } \\
\text { change from Done to Active to Abort }\end{array}$ & \\
\hline 7. & $\begin{array}{l}\text { Take one or more sensor } \\
\text { out of the test mode. } \\
\text { Click the Update button } \\
\text { Wait until Table } \\
\text { Processing Status } \\
\text { displays DONE. }\end{array}$ & $\begin{array}{l}\text { Verify the following: } \\
\text { - Report Table is updated with the } \\
\text { appropriate sensors } \\
\text { - Date of Report is updated. }\end{array}$ & \\
\hline
\end{tabular}


HNF-3967, Rev. 4

\begin{tabular}{|c|c|c|c|}
\hline Step & Perform & Expected Result & $\begin{array}{c}\text { Initia } \\
1\end{array}$ \\
\hline 8. & $\begin{array}{l}\text { Click on the Title block } \\
\text { of the report table. }\end{array}$ & $\begin{array}{l}\text { Verify the help workspace for this report is } \\
\text { displayed. }\end{array}$ & \\
\hline 9. & $\begin{array}{l}\text { Click the Maximize } \\
\text { button. }\end{array}$ & Verify the workspace is maximized. & \\
\hline 10. & $\begin{array}{l}\text { Click the Minimize } \\
\text { button }\end{array}$ & Verify the workspace is minimized & \\
\hline 11. & $\begin{array}{l}\text { Click on the Top of } \\
\text { report button }(1<)\end{array}$ & $\begin{array}{l}\text { Verify that the portion of the report } \\
\text { displayed is the first page in the report. } \\
\text { (Note: Report may fit on one page and } \\
\text { therefore no change is seen.) }\end{array}$ & \\
\hline 12. & $\begin{array}{l}\text { Click on the End of } \\
\text { report button }(-\mid) \text {. }\end{array}$ & $\begin{array}{l}\text { Verify the portion of the report displayed is } \\
\text { the last page in the report. (Note: Report } \\
\text { may fit on one page and therefore no } \\
\text { change is seen.) }\end{array}$ & \\
\hline 13. & $\begin{array}{l}\text { Click the Previous page } \\
\text { button }(\varangle)\end{array}$ & $\begin{array}{l}\text { Verify the portion of the report displayed is } \\
\text { the previous page. (Note: Report may fit on } \\
\text { one page and therefore no change is seen.) }\end{array}$ & \\
\hline 14. & $\begin{array}{l}\text { Click the Next page } \\
\text { button( }() \text {. }\end{array}$ & $\begin{array}{l}\text { Verify the portion of the report displayed is } \\
\text { the next page. (Note: Report may fit on one } \\
\text { page and therefore no change is seen.) }\end{array}$ & \\
\hline 15 . & $\begin{array}{l}\text { Click on the Print } \\
\text { button (P). (Note: Not } \\
\text { functional on the remote } \\
\text { stations at this time.) }\end{array}$ & $\begin{array}{l}\text { Verify the portion of the workspace } \\
\text { displayed is printed to the printer. }\end{array}$ & \\
\hline 16. & $\begin{array}{l}\text { Click on the Hide button } \\
(\mathrm{X}) \text {. }\end{array}$ & Verify the report workspace is hidden. & \\
\hline
\end{tabular}

\subsection{EXTERNAL INTERFACES}

\subsubsection{Acromag ${ }^{\mathrm{TM}}$}

The tests in this section require the use of an Acromag ${ }^{\mathrm{TM}}$ emulator. The test should be run on the development machine. 
HNF-3967, Rev. 4

\subsubsection{Conversion of AcromagTM Temperature Output to Engineering Units}

\begin{tabular}{|c|c|c|c|}
\hline Step & Perform & Expected Result & Initial \\
\hline 1. & $\begin{array}{l}\text { From the tag list, choose } \\
\text { an Acromag } \\
\text { sensor temperature } \\
\text { Display the Sensor Details } \\
\text { for the chosen sensor. } \\
\text { Press the Update button } \\
\text { then use the Formula } \\
\text { expression and Raw Value } \\
\text { to calculate the current } \\
\text { reading for the sensor. }\end{array}$ & Write the value here & \\
\hline 2. & $\begin{array}{l}\text { Compare the Current } \\
\text { Reading with the reading } \\
\text { in Step 1. }\end{array}$ & Verify that the readings are the same. & \\
\hline 3. & $\begin{array}{l}\text { Display the history details } \\
\text { for this sensor. }\end{array}$ & $\begin{array}{l}\text { Verify that the value is displayed and matches } \\
\text { the value recorded in Step 1. (Note: It is } \\
\text { possible for the value to be displayed more than } \\
\text { once in the history details if it crosses a limit } \\
\text { boundary.) }\end{array}$ & \\
\hline
\end{tabular}

\subsubsection{Conversion of AcromagrM 4 to $20 \mathrm{ma}$ Output to Engineering Units}

\begin{tabular}{|l|l|l|l|}
\hline Step & \multicolumn{1}{|c|}{ Perform } & \multicolumn{1}{c|}{ Expected Result } & Initial \\
\hline 1. & $\begin{array}{l}\text { From the tag list, choose } \\
\text { an AcromagTM non- } \\
\text { temperature sensor at } \\
\text { random, e.g., pressure, } \\
\text { flow, surface level, .. } \\
\text { Display the Sensor Details } \\
\text { for the chosen sensor. } \\
\text { Press the Update button } \\
\text { then use the Formula } \\
\text { expression and Raw Value } \\
\text { to calculate the current } \\
\text { reading for the sensor. }\end{array}$ & Write the value here & \\
\hline 2. & $\begin{array}{l}\text { Compare the Current } \\
\text { Reading with the reading } \\
\text { in Step I. }\end{array}$ & Verify that the readings are the same. & \\
\hline
\end{tabular}


HNF-3967, Rev. 4

\begin{tabular}{|l|l|l|l|}
\hline Step & \multicolumn{1}{|c|}{ Perform } & \multicolumn{1}{c|}{ Expected Result } & Initial \\
\hline 3. & $\begin{array}{l}\text { Display the history details } \\
\text { for this sensor. }\end{array}$ & $\begin{array}{l}\text { Verify that the value is displayed and matches } \\
\text { the value recorded in Step 1. Note: It is } \\
\text { possible for the value to be displayed more than } \\
\text { once in the history details if it crosses a limit } \\
\text { boundary.) }\end{array}$ & \\
\hline
\end{tabular}

\subsubsection{Conversion of Acromag ${ }^{\mathrm{TM}}$ Digital Data to Discrete States}

The Acromag ${ }^{\mathrm{TM}}$ emulator does not directly support digital input for the Acromag ${ }^{\mathrm{TM}}$. A digital value of 0 may be simulated with a temperature value of $32.0 \mathrm{~F}$. A digital 1 is simulated with a temperature of $32.18 \mathrm{~F}$. Any other value will be an unknown state.

\begin{tabular}{|l|l|l|l|}
\hline Step & \multicolumn{1}{|c|}{ Perform } & \multicolumn{1}{c|}{ Expected Result } & Initial \\
\hline 1. & $\begin{array}{l}\text { Using the tag list, choose } \\
\text { an enabled Acromag } \\
\text { digital sensor at random. } \\
\text { Use the emulator to } \\
\text { simulate a value of digital } \\
0 \text { for this sensor. } \\
\begin{array}{l}\text { After an appropriate delay } \\
\text { for the TMACS to poll the } \\
\text { emulator for this sensor. }\end{array}\end{array}$ & Verify that the sensor is in alarm. & \\
\hline 2. & $\begin{array}{l}\text { Use the emulator to } \\
\text { simulate a value of digital } \\
1 \text { for this sensor. } \\
\text { After an appropriate delay } \\
\text { for the TMACS to poll the } \\
\text { emulator for this sensor. }\end{array}$ & & \\
\hline
\end{tabular}

\subsubsection{Enraf}

The tests in this section require the use of an Enraf ${ }^{*}$ emulator. The test should be run on the development machine. 
HNF-3967, Rev. 4

\subsubsection{Conversion of Enraf ${ }^{\circledast 1 U}$ Level Sensor Output to Engineering Units}

\begin{tabular}{|c|c|c|c|}
\hline Step & Perform & Expected Result & Initial \\
\hline 1. & $\begin{array}{l}\text { From the tag list, choose } \\
\text { an Enraf }{ }^{\infty} \text { CIU level sensor } \\
\text { at random. } \\
\text { Display the Sensor Details } \\
\text { for the chosen sensor. } \\
\text { Press the Update button } \\
\text { then use the Formula } \\
\text { expression and Raw Value } \\
\text { to calculate the current } \\
\text { reading for the sensor. }\end{array}$ & Write the value here & \\
\hline 2. & $\begin{array}{l}\text { Compare the Current } \\
\text { Reading with the reading } \\
\text { in Step 1. }\end{array}$ & Verify that the readings are the same. & \\
\hline 3. & $\begin{array}{l}\text { Display the history details } \\
\text { for this sensor. }\end{array}$ & $\begin{array}{l}\text { Verify that the value is displayed and matches } \\
\text { the value recorded in Step } 1 \text {. (Note: It is } \\
\text { possible for the value to be displayed more than } \\
\text { once in the history details if it crosses a limit } \\
\text { boundary.) }\end{array}$ & \\
\hline
\end{tabular}

\subsubsection{Conversion of Enraf CIU Pressure Sensor Output to Engineering Units}

\begin{tabular}{|l|l|l|l|}
\hline Step & \multicolumn{1}{|c|}{ Perform } & \multicolumn{1}{c|}{ Expected Result } & Initial \\
\hline 4. & $\begin{array}{l}\text { From the tag list, choose } \\
\text { an Enraf } \\
\text { sensor at ran pressure } \\
\text { Display the Sensor Details } \\
\text { for the chosen sensor. } \\
\begin{array}{l}\text { Press the Update button } \\
\text { then use the Formula } \\
\text { expression and Raw Value } \\
\text { to calculate the current } \\
\text { reading for the sensor. }\end{array}\end{array}$ & Write the value here & \\
\hline 5. & $\begin{array}{l}\text { Compare the Current } \\
\text { Reading with the reading } \\
\text { in Step 1. }\end{array}$ & Verify that the readings are the same. & \\
\hline
\end{tabular}


HNF-3967, Rev. 4

\begin{tabular}{|l|l|l|l|}
\hline Step & \multicolumn{1}{|c|}{ Perform } & \multicolumn{1}{c|}{ Expected Result } & Initial \\
\hline 6. & $\begin{array}{l}\text { Display the history details } \\
\text { for this sensor. }\end{array}$ & $\begin{array}{l}\text { Verify that the value is displayed and matches } \\
\text { the value recorded in Step 1. Note: It is } \\
\text { possible for the value to be displayed more than } \\
\text { once in the history details if it crosses a limit } \\
\text { boundary.) }\end{array}$ & \\
\hline
\end{tabular}

\subsubsection{Conversion of Enraf ${ }^{\circ}$ CIU Alarm Status to Discrete States}

\begin{tabular}{|c|c|c|c|}
\hline Step & Perform & Expected Result & Initial \\
\hline 1. & $\begin{array}{l}\text { From the tag list, choose } \\
\text { an Enraf CIU discrete } \\
\text { sensor at random. } \\
\text { Use the emulator to } \\
\text { simulate a High Alarm for } \\
\text { this sensor. } \\
\text { After an appropriate delay } \\
\text { for the TMACS to poll the } \\
\text { emulator for this sensor or } \\
\text { use the update button on } \\
\text { the sensor details }\end{array}$ & Verify that the sensor is in High alarm. & \\
\hline 2. & $\begin{array}{l}\text { Use the emulator to } \\
\text { simulate a Normal for this } \\
\text { sensor. } \\
\text { After an appropriate delay } \\
\text { for the TMACS to poll the } \\
\text { emulator for this sensor or } \\
\text { use the update button on } \\
\text { the sensor details }\end{array}$ & Verify that the sensor is in Reset (Normal). & \\
\hline 3. & $\begin{array}{l}\text { Use the emulator to } \\
\text { simulate a Low Alarm for } \\
\text { this sensor. } \\
\text { After an appropriate delay } \\
\text { for the TMACS to poll the } \\
\text { emulator for this sensor or } \\
\text { use the update button on } \\
\text { the sensor details. }\end{array}$ & Verify that the sensor is in Low alarm. & \\
\hline
\end{tabular}


HNF-3967, Rev. 4

\begin{tabular}{|l|l|l|l|}
\hline Step & \multicolumn{1}{|c|}{ Perform } & \multicolumn{1}{c|}{ Expected Result } & Initial \\
\hline 4. & $\begin{array}{l}\text { Use the emulator to } \\
\text { simulate a Normal for this } \\
\text { sensor. }\end{array}$ & $\begin{array}{l}\text { Verify that the sensor is in Reset (Normal). } \\
\text { After an appropriate delay } \\
\text { for the TMACS to poll the } \\
\text { emulator for this sensor or } \\
\text { use the update button on } \\
\text { the sensor details }\end{array}$ & \\
\hline
\end{tabular}

\subsubsection{Westronics}

The tests in this section require the use of a Westronics ${ }^{\infty}$ emulator. The test should be run on the development machine.

\subsubsection{Conversion of Westronics ${ }^{(*)}$ Temperature Output to Engineering Units}

\begin{tabular}{|c|c|c|c|}
\hline Step & Perform & Expected Result & Initial \\
\hline 1. & $\begin{array}{l}\text { From the tag list, choose a } \\
\text { Westronics }{ }^{\text {temperature }} \\
\text { sensor at random. } \\
\text { Display the Sensor Details } \\
\text { for the chosen sensor. } \\
\text { Press the Update button } \\
\text { then use the Formula } \\
\text { expression and Raw Value } \\
\text { to calculate the current } \\
\text { reading for the sensor. }\end{array}$ & Write the value here & \\
\hline 2. & $\begin{array}{l}\text { Compare the Current } \\
\text { Reading with the reading } \\
\text { in Step } 1 .\end{array}$ & Verify that the readings are the same. & \\
\hline 3. & $\begin{array}{l}\text { Display the history details } \\
\text { for this sensor. }\end{array}$ & $\begin{array}{l}\text { Verify that the value is displayed and matches } \\
\text { the value recorded in Step } 1 \text {. Note: It is } \\
\text { possible for the value to be displayed more than } \\
\text { once in the history details if it crosses a limit } \\
\text { boundary.) }\end{array}$ & \\
\hline
\end{tabular}

\subsubsection{Panalarm ${ }^{(*)}$}

The tests in this section require the use of a Panalarm ${ }^{\infty}$ emulator. The test should be run on the development machine. 
HNF-3967, Rev. 4

\subsubsection{Conversion of Panalarm ${ }^{\circledast}$ Output to Digital Data to Discrete States}

\begin{tabular}{|l|l|l|l|}
\hline Step & \multicolumn{1}{|c|}{ Perform } & \multicolumn{1}{c|}{ Expected Result } & Initial \\
\hline 1. & $\begin{array}{l}\text { Using the tag list, choose a } \\
\text { Panalarm sensor at } \\
\text { random. } \\
\text { Use the emulator to } \\
\text { simulate a value of digital } \\
1 \text { for this sensor. } \\
\text { After an appropriate delay } \\
\text { for the TMACS to poll the } \\
\text { emulator for this sensor. }\end{array}$ & Verify that the sensor is in alarm. & \\
\hline 2. & $\begin{array}{l}\text { Use the emulator to } \\
\text { simulate a value of digital } \\
\text { 0 for this sensor. } \\
\text { After an appropriate delay } \\
\text { for the TMACS to poll the } \\
\text { emulator for this sensor. }\end{array}$ & Verify that the sensor is reset. & \\
\hline 3. & \begin{tabular}{l} 
Return to the main screen. \\
\hline
\end{tabular}
\end{tabular}

\subsubsection{SACS}

TMACS retrieves surface level data from SACS whenever TMACS starts and at 2000 every evening thereafter. The "last SACS reading" will be the last reading taken and marked good (the quality status was set to "G") before TMACS retrieves that data.

\begin{tabular}{|c|c|c|c|}
\hline Step & Perform & Expected Result & Initial \\
\hline 1. & $\begin{array}{l}\text { Select a surface-level } \\
\text { sensor has been configured } \\
\text { for polling from SACS. }\end{array}$ & $\begin{array}{l}\text { Record the sensor and tank names. } \\
\text { Sensor } \\
\text { Tank }\end{array}$ & \\
\hline 2. & $\begin{array}{l}\text { On the Hanford Tank Farm } \\
\text { Facilities workspace, click } \\
\text { on the tank icon for the } \\
\text { selected tank. } \\
\text { Click on the surface-level } \\
\text { icon. }\end{array}$ & $\begin{array}{l}\text { Verify that the Sensor Trend workspace } \\
\text { appears. }\end{array}$ & \\
\hline 3. & $\begin{array}{l}\text { Click on the detail button. } \\
\text { (Upper right-hand corner } \\
\text { of the Sensor Trend } \\
\text { workspace.) } \\
\text { Click on the Update (U) } \\
\text { button. }\end{array}$ & $\begin{array}{l}\text { Verify that the details about the surface-level } \\
\text { sensor appear. } \\
\text { Record the: } \\
\text { Current Reading } \\
\text { Last Good Reading } \\
\text { Sensor Type Name } \\
\text { slvl dttm }\end{array}$ & \\
\hline
\end{tabular}


HNF-3967, Rev. 4

\begin{tabular}{|l|l|l|l|}
\hline Step & \multicolumn{1}{|c|}{ Perform } & Initial \\
\hline 4. & $\begin{array}{l}\text { Close the Sensor Trend } \\
\text { workspace. }\end{array}$ & \multicolumn{1}{|c|}{ Expected Result } & \\
\hline 5. & $\begin{array}{l}\text { Obtain the last SACS } \\
\text { database reading for the } \\
\text { selected tank. Note: This } \\
\text { will be on the UDO server } \\
\text { most likely.) This may be } \\
\text { obtained from the system } \\
\text { administrator using the } \\
\text { following code: } \\
\text { lp_LastSLVLReading } \\
\text { 'Tank Name]' } \\
\text { match the values recorded in Step 3. } \\
\text { select* }\end{array}$ & $\begin{array}{l}\text { Verify that the values obtained in this step } \\
\text { fom } \\
\text { DING }\end{array}$ & \\
\hline
\end{tabular}

\subsection{POINT PROCESSING}

\subsubsection{Continuous Sensor (Non Rate of Change) Automated Functional Test}

This procedure automatically tests the state changes for a continuous sensor.

\begin{tabular}{|l|l|l|l|}
\hline Step & \multicolumn{1}{|c|}{ Perform } & \multicolumn{1}{c|}{ Expected Result } & Initial \\
\hline 1. & $\begin{array}{l}\text { On the POINT } \\
\text { PROCESSING } \\
\text { FUNCTIONAL TEST } \\
\text { workspace click on the } \\
\text { Point Processing for } \\
\text { Continuous Point - All } \\
\text { Function excepts Rate of } \\
\text { Change button }\end{array}$ & $\begin{array}{l}\text { Verify the CONTINUOUS FUNCTIONAL } \\
\text { TEST (Except ROC) workspace appears. }\end{array}$ & \\
\hline 2. & $\begin{array}{l}\text { On the CONTINUOUS } \\
\text { FUNCTIONAL TEST } \\
\text { (Except ROC) workspace: } \\
\text { Set the Step Mode to } \\
\text { "Off." } \\
\text { Set Print Results to } \\
\text { "Last" } \\
\text { Activate the "Run Point } \\
\text { Processing" button. }\end{array}$ & Verify that the process continues to completion & \\
\hline 3. & $\begin{array}{l}\text { Examine the results } \\
\text { Examify no errors are reported. }\end{array}$ & \\
\hline
\end{tabular}




\begin{tabular}{|l|l|l|l|}
\hline Step & \multicolumn{1}{|c|}{ Perform } & Expected Result & Initial \\
\hline 4. & Print the final workspace. & Keep printout for project files. & \\
\hline
\end{tabular}

\subsubsection{Continuous Sensor (Rate of Change) Automated Functional Test}

\begin{tabular}{|l|l|l|l|}
\hline Step & \multicolumn{1}{|c|}{ Perform } & \multicolumn{1}{c|}{ Expected Result } & Initial \\
\hline 1. & $\begin{array}{l}\text { On the POINT } \\
\text { PROCESSING } \\
\text { FUNCTIONAL TEST } \\
\text { workspace click on the } \\
\text { Point Processing for } \\
\text { Continuous Point -Rate } \\
\text { of Change button. }\end{array}$ & Verify the CONTINUOUS FUNCTIONAL & TEST (With ROC) workspace appears. \\
\hline 2. & $\begin{array}{l}\text { On the ROC } \\
\text { FUNCTIONAL TEST } \\
\text { workspace: } \\
\text { Set the Step Mode to } \\
\text { "Off." } \\
\text { Set Print Results to "Last" } \\
\text { Activate the "Run Point } \\
\text { Processing" button. }\end{array}$ & Verify that the process continues to completion. & \\
\hline 3. & Examine the workspace. & Verify no errors are reported. & \\
\hline 4. & Print the final workspace. & Keep printout for project files. & \\
\hline
\end{tabular}

\subsubsection{Discrete Sensor Automated Functional Test}

This procedure automatically tests the state changes of a discrete sensor.

\begin{tabular}{|l|l|l|l|}
\hline Step & \multicolumn{1}{|c|}{ Perform } & \multicolumn{1}{c|}{ Expected Result } & Initial \\
\hline 1. & $\begin{array}{l}\text { On the POINT } \\
\text { PROCESSING } \\
\text { FUNCTIONAL TEST } \\
\text { workspace click on the } \\
\text { Point Processing for } \\
\text { Discrete Points - All } \\
\text { Functions button }\end{array}$ & $\begin{array}{l}\text { Verify the DISCRETE FUNCTIONAL TEST } \\
\text { workspace appears. }\end{array}$ & \\
\hline 2. & $\begin{array}{l}\text { On the Discrete Functional } \\
\text { Test workspace: } \\
\text { Set the Step Mode to } \\
\text { "Off." } \\
\text { Set Print Results to "Last" } \\
\text { Activate the " Run Point } \\
\text { Processing " button. }\end{array}$ & Verify that the process continues to completion. & \\
\hline 3. & Examine the workspace. & Verify no errors are reported. & \\
\hline 4. & Print the final workspace. & Keep printout for project files. & \\
\hline
\end{tabular}




\subsubsection{Operation of MOST RECENT ALARM and CURRENT ALARMS}

Prior to running this test the administrator should do the following:

1. Acknowledge all alarms so Current Alarm count goes to zero. Note: if this is not done, then note the number of current alarms.

2. Verify the following workspaces are visible:

- DISCRETE FUNCTIONAL TEST

- MOST RECENT ALARM

- CONTROL-PANEL

- CURRENT ALARM

\begin{tabular}{|c|c|c|c|}
\hline Step & Perform & Expected Result & Initial \\
\hline 1. & $\begin{array}{l}\text { On the Discrete Functional } \\
\text { Test Workspace } \\
\text { Set the Step Mode in ON. } \\
\text { Activate the RUN POINT } \\
\text { PROCESSING button. } \\
\text { Examine the Current } \\
\text { Alarm box. }\end{array}$ & Note the number of current alarms & \\
\hline 2. & $\begin{array}{l}\text { Enter } 4 \text { in Dip-switch type- } \\
\text { in box on the Discrete } \\
\text { Functional Test } \\
\text { Workspace. }\end{array}$ & $\begin{array}{l}\text { Verify the following: } \\
\text { - A white message for the discrete alarm is } \\
\text { generated in the MOST RECENT ALARM } \\
\text { workspace. } \\
\text { - Sensor Icon Blinking = false } \\
\text { - Tank Icon Blinking = false } \\
\text { - No Current Alarms = } 1 \text { more than Step I on } \\
\text { the following workspaces: } \\
\text { 1. CURRENT ALARMS } \\
\text { 2. CONTROL PANEL } \\
\text { 3. MOST RECENT ALARM }\end{array}$ & \\
\hline 3. & $\begin{array}{l}\text { Enter }-1 \text { in Dip-switch } \\
\text { type-in box on the } \\
\text { Discrete Functional Test } \\
\text { Workspace. }\end{array}$ & $\begin{array}{l}\text { Verify the following: } \\
\text { - Sensor Icon Blinking = false } \\
\text { - Tank Icon Blinking = false } \\
\text { - No Current Alarms = } 1 \text { more than Step I on } \\
\text { the following workspaces: } \\
\text { 1. CURRENT ALARMS } \\
\text { 2. CONTROL PANEL } \\
\text { 3. MOST RECENT ALARM }\end{array}$ & \\
\hline 4. & $\begin{array}{l}\text { Enter } \underline{2} \text { in Dip-switch type- } \\
\text { in box on the Discrete } \\
\text { Functional Test } \\
\text { Workspace. }\end{array}$ & $\begin{array}{l}\text { Verify the following: } \\
\text { - A discrete alarm message is generated in } \\
\text { the MOST RECENT ALARM workspace. } \\
\text { - Sensor Icon Blinking = true }\end{array}$ & \\
\hline
\end{tabular}




\begin{tabular}{|c|c|c|c|}
\hline Step & Perform & Expected Result & Initial \\
\hline & & $\begin{array}{l}\text { - Tank Icon Blinking }=\text { true } \\
\text { - No. Current Alarms }=2 \text { more than in Step } 1 \\
\text { on the following workspaces: } \\
\text { 1. CURRENT ALARMS } \\
\text { 2. CONTROL PANEL } \\
\text { 3. MOST RECENT ALARM }\end{array}$ & \\
\hline 5. & $\begin{array}{l}\text { On the Most Recent Alarm } \\
\text { workspace activate the } \\
\text { GOTO button }\end{array}$ & $\begin{array}{l}\text { Verify the following: } \\
\text { - TANK TEST-201 STATUS workspace is } \\
\text { brought to the top of the screen. } \\
\text { - The sensor is in alarm. }\end{array}$ & \\
\hline 6 & $\begin{array}{l}\text { Enter } 0 \text { in Dip-switch type- } \\
\text { in box on the Discrete } \\
\text { Functional Test } \\
\text { Workspace. }\end{array}$ & $\begin{array}{l}\text { Verify the following: } \\
\text { - Discrete alarm message is reset. } \\
\text { - No. Current Alarms }=2 \text { more than Step } 1 \\
\text { on the following workspaces: } \\
\text { 1. CURRENT ALARMS } \\
\text { 2. CONTROL PANEL } \\
\text { 3. MOST RECENT ALARM }\end{array}$ & \\
\hline 7. & $\begin{array}{l}\text { Acknowledge alarm } \\
\text { message in MOST } \\
\text { RECENT ALARM } \\
\text { Window by clicking on it. }\end{array}$ & $\begin{array}{l}\text { Verify the following: } \\
\text { - Alarm Message disappears. } \\
\text { - Sensor Icon Blinking = false } \\
\text { Tank Icon Blinking = false } \\
\text { - No. Current Alarms = } 1 \text { more than Step } 1 \\
\text { on the following workspaces: } \\
\text { 1. CURRENT ALARMS } \\
\text { 2. CONTROL PANEL } \\
\text { 3. MOST RECENT ALARM }\end{array}$ & \\
\hline 8 & $\begin{array}{l}\text { Acknowledge the White } \\
\text { alarm message }\end{array}$ & $\begin{array}{l}\text { Verify the following: } \\
\text { Alarm Message disappears } \\
\text { - Sensor Icon Blinking = false } \\
\text { Tank Icon Blinking = false } \\
\text { - No. Current Alarms = the same as in Step } 1 \\
\text { on the following workspaces: } \\
\text { 1. CURRENT ALARMS } \\
\text { 2. CONTROL PANEL } \\
\text { 3. MOST RECENT ALARM }\end{array}$ & \\
\hline
\end{tabular}

\subsubsection{Operation of Sensor Delta Band and Alarm Deadband}

This test will verify that the operation of the sensor band and the alarm deadband for continuous sensors.

Prior to running this test the administrator should do the following: 
HNF-3967, Rev. 4

1. Verify that the Rate of Change processing is disabled for Sensor Continuous-200001.

2. Verify that the parameters for Sensor Continuous-200001 are set to match the parameters in Table 1. (See Prerequisites)

3. Verify that the following workspaces are visible.

- CONTINUOUS FUNCTIONAL TEST

- MOST RECENT ALARM

\begin{tabular}{|c|c|c|c|}
\hline Step & Action & Verify the Alarm Condition is: & Initial \\
\hline 1. & $\begin{array}{l}\text { On the Continuous Functional Test } \\
\text { Workspace } \\
\text { Set the Step Mode in ON. } \\
\text { Activate the RUN POINT } \\
\text { PROCESSING button. } \\
\text { Enter } 14.8 \text { in milli-amps type-in } \\
\text { box }\end{array}$ & NORMAL & \\
\hline 2. & Enter 14.4 in milli-amps type-in box & NORMAL & \\
\hline 3. & Enter 14.3 in milli-amps type-in box & NORMAL & \\
\hline 4. & Enter 14.8 in milli-amps type-in box & NORMAL & \\
\hline 5. & Enter 15.2 in milli-amps type-in box & ALARM-HIGH & \\
\hline 6. & Enter 15.3 in milli-amps type-in box & ALARM-HIGH & \\
\hline 7. & Enter 14.9 in milli-amps type-in box & ALARM-HIGH & \\
\hline 8. & Enter 14.6 in milli-amps type-in box & ALARM-HIGH & \\
\hline 9. & Enter 14.0 in milli-amps type-in box & NORMAL & \\
\hline 10. & Enter 13.5 in milli-amps type-in box & NORMAL & \\
\hline 11. & Enter 15.0 in milli-amps type-in box & ALARM-HIGH & \\
\hline 12. & Enter 10.6 in milli-amps type-in box & NORMAL & \\
\hline 13. & Enter 15.0 in milli-amps type-in box & ALARM-HIGH & \\
\hline 14. & Enter 9.9 in milli-amps type-in box & ALARM-LOW & \\
\hline 15. & Enter $\mathbf{1 0 . 2}$ in milli-amps type-in box & ALARM-LOW & \\
\hline 16. & Enter 10.5 in milli-amps type-in box & ALARM-LOW & \\
\hline 17. & Enter 11.0 in milli-amps type-in box & NORMAL & \\
\hline 18. & Enter 11.5 in milli-amps type-in box & NORMAL & \\
\hline
\end{tabular}

\subsubsection{Operation of Enable/Disable Procedures}

Verify that the following workspaces are visible.

- Continuous Function Test

- Tank Test-201

- Enable/Disable Point Processing

- Most Recent Alarm

- Discrete-200001 Sensor 


\begin{tabular}{|c|c|c|c|}
\hline Step & Perform & Expected Result & Initial \\
\hline 1. & $\begin{array}{l}\text { On the Continuous } \\
\text { Functional Test } \\
\text { workspace enter } 17 \text { in the } \\
\text { "milliamps" type-in box. }\end{array}$ & $\begin{array}{l}\text { Verify the following: } \\
\text { - Alarm message is displayed } \\
\text { - Number of Current Alarms increases by } \\
\text { one. }\end{array}$ & \\
\hline 2. & $\begin{array}{l}\text { Position the enable/disable } \\
\text { pointer over the } \\
\text { Continuous-200001 sensor } \\
\text { and activate the button } \\
\text { "Toggle Point". }\end{array}$ & $\begin{array}{l}\text { Verify that the following conditions occur: } \\
\text { - Blue message is displayed: "The POINT- } \\
\text { PROCESSING of CONTINUOUS-200001 } \\
\text { has been DISABLED", with the timestamp } \\
\text { of this change. } \\
\text { - Previous alarm message disappears and the } \\
\text { total "Number of Current Alarms" remains } \\
\text { the same. } \\
\text { - Point processing attribute of sensor changes } \\
\text { to false. } \\
\text { - Sensor turns gray. } \\
\text { Tank color is the same as the DISCRETE- } \\
200001 \text { sensor color. }\end{array}$ & \\
\hline 3. & $\begin{array}{l}\text { With the enable/disable } \\
\text { pointer still over the } \\
\text { Continuous-200001 sensor, } \\
\text { activate the button "Toggle } \\
\text { Point". }\end{array}$ & $\begin{array}{l}\text { Verify that the following conditions occur: } \\
\text { - Blue message is displayed: "The POINT- } \\
\text { PROCESSING of CONTINUOUS-200001 } \\
\text { has been ENABLED", with the timestamp } \\
\text { of this change. } \\
\text { - "Number of Current Alarms" remains the } \\
\text { same. } \\
\text { - Point processing attribute of sensor changes } \\
\text { to true. } \\
\text { - Sensor turns white. } \\
\text { - Tank color will be based on the alarm } \\
\text { precedence of the sensors associated with } \\
\text { the tank. }\end{array}$ & \\
\hline 4. & $\begin{array}{l}\text { Select a tank on the HTFF } \\
\text { workspace that has a good } \\
\text { mix of sensor types. } \\
\text { Enter the chosen tank in } \\
\text { the type-in box labeled } \\
\text { "Tank on which to enable / } \\
\text { disable point processing". } \\
\text { Without moving the } \\
\text { enable/disable pointer } \\
\text { activate the button "Toggle } \\
\text { Point". }\end{array}$ & $\begin{array}{l}\text { Verify that the following conditions occur: } \\
\text { - Blue message is displayed: "The POINT- } \\
\text { PROCESSING of [the nearest sensor to the } \\
\text { pointer-frequently the level sensor] has } \\
\text { been DISABLED", with the timestamp of } \\
\text { this change; } \\
\text { - Point processing attribute of sensor changes } \\
\text { to false; } \\
\text { - Sensor turns gray; } \\
\text { - Tank color is the same as the highest } \\
\text { priority sensor alarm }\end{array}$ & \\
\hline
\end{tabular}




\begin{tabular}{|c|c|c|c|}
\hline Step & Perform & Expected Result & Initial \\
\hline 5 & $\begin{array}{l}\text { Activate the button } \\
\text { "Toggle Point" again. }\end{array}$ & $\begin{array}{l}\text { Verify that the following conditions occur: } \\
\text { - Blue message is displayed: "The POINT- } \\
\text { PROCESSING of [the nearest sensor to the } \\
\text { pointer] has been ENABLED", with the } \\
\text { timestamp of this change; } \\
\text { - Point processing attribute of sensor changes } \\
\text { to true; } \\
\text { - Sensor turns white; } \\
\text { - Tank icon turns white or the color of the } \\
\text { highest priority sensor alarm. }\end{array}$ & \\
\hline 6. & $\begin{array}{l}\text { Activate the button "All } \\
\text { points in tank off". }\end{array}$ & $\begin{array}{l}\text { Verify that the following conditions occur: } \\
\text { - Blue messages are displayed: "The POINT- } \\
\text { PROCESSING of [each sensor monitoring } \\
\text { this tank] has been DISABLED" with the } \\
\text { time of this change; } \\
\text { - Point processing attribute of sensors } \\
\text { changes to false; } \\
\text { - Sensors turn gray; } \\
\text { - All sensor alarms associated with this tank } \\
\text { are cleared; } \\
\text { - Tank color turns gray. }\end{array}$ & \\
\hline 7. & $\begin{array}{l}\text { Activate the button "All } \\
\text { points in tank on". }\end{array}$ & $\begin{array}{l}\text { Verify that the following conditions occur: } \\
\text { Blue messages are displayed: "The PONNT- } \\
\text { PROCESSING of [each sensor monitoring } \\
\text { this tank] has been ENABLED" with the } \\
\text { time of this change; } \\
\text { - Point processing attribute of sensors } \\
\text { changes to true; } \\
\text { - Sensors turn white; } \\
\text { - Tank turns white. }\end{array}$ & \\
\hline 8. & $\begin{array}{l}\text { On the Current Alarms } \\
\text { workspace click on the } \\
\text { Clear All Blue Messages } \\
\text { button. }\end{array}$ & $\begin{array}{l}\text { Verify the Blue Messages disappear from the } \\
\text { Current Alarms list. }\end{array}$ & \\
\hline 9 . & $\begin{array}{l}\text { Hide the following } \\
\text { workspaces: } \\
\text { - Tank (selected in test) } \\
\text { - Enable/Disable Point } \\
\text { Processing } \\
\text { - Discrete-200001 } \\
\text { Sensor }\end{array}$ & Verify the workspaces are hidden. & \\
\hline
\end{tabular}




\subsubsection{Miscellaneous Alarm Tests}

The purpose of this test is to verify the relationships between the sensor icons, tank icon, Current Alarms Workspace and the annuciator.

Prior to running this test the administrator should do the following:

1. Make sure the following workspaces visible.

- Functional Test Selection Workspace (Only to see the TANK-ICON-TEST-201 icon)

- Continuous Functional Test Workspace. Also perform following:

1. Set Step Mode On

2. Activate the Run Point Processing button

- Discrete Functional Test Workspace. Also perform following:

1. Set Step Mode On

2. Activate the Run Point Processing button

- TANK TEST-201 workspace.

- MOST RECENT ALARM workspace

- Discrete-200001 Sensor

2. Make sure the enunciator is enabled. This is done by the following:

- Bring up the TMACS-LIB workspace and its subworkspace labeled STARTUP-WS and Activate the "TOGGLE-AUDIBLE" button and verify that the display of the alarm-audible symbol changes from false to true.

\begin{tabular}{|c|c|c|c|}
\hline Step & Perform & Expected Result & Initial \\
\hline 1. & $\begin{array}{l}\text { Enter } 1 \text { in Dip-switch type-in box } \\
\text { on the Discrete Functional Test } \\
\text { Workspace. } \\
\text { Enter a } 11 \text { in Milli-amp type-in } \\
\text { box on the Continuous } \\
\text { Functional Test Workspace } \\
\text { Note: May have to click on the } \\
\text { Run Point Process button on both } \\
\text { the Discrete and Contimuous } \\
\text { Function Test Workspaces. }\end{array}$ & $\begin{array}{l}\text { Beep } \\
\text { Beep }=\text { true } \\
\text { Most Recent Alarm } \\
\text { - Message Status = Closing } \\
\text { - Display Color = Yellow } \\
\text { - } \quad \text { Text Color = Red } \\
\text { Discrete Functional Test Workspace } \\
\text { Discrete - 2001 } \\
\text { - Discrete Icon Blinking = true } \\
\text { - Display Color = YELLOW } \\
\text { - Blink-off Color = GRAY } \\
\text { - } \quad \text { Alarm Aux Color = YELLOW }\end{array}$ & \\
\hline
\end{tabular}


HNF-3967, Rev. 4

\begin{tabular}{|c|c|c|c|}
\hline Step & Perform & Expected Result & Initial \\
\hline & & $\begin{array}{l}\text { Tank Icon Test-201 } \\
\text { - } \quad \text { Icon Blinking }=\text { true } \\
\text { - } \text { Display Color = YELLOW } \\
\text { - Blink-off Color = GRAY } \\
\text { Latest Alarm Message } \\
\text { - Display Color = Yellow } \\
\text { Continuous Functional Test Workspace } \\
\text { Continuous -2001 } \\
\text { - Cont. lcon Blinking = false } \\
\text { Display Color = GREEN } \\
\text { Blink-off Color = (N/A - skip) } \\
\text { - Alarm Aux Color = TRANSPARENT } \\
\text { Tank Icon Test-201 } \\
\text { - Icon Blinking = true } \\
\text { - Display Color = YELLOW } \\
\text { - Blink-off Color = GRAY } \\
\text { Latest Alarm Message } \\
\text { - Display Color = Yellow }\end{array}$ & \\
\hline 2. & $\begin{array}{l}\text { Activate ACK ALARMS Button } \\
\text { on Tank Test } 201 \text { status }\end{array}$ & $\begin{array}{l}\text { Beep } \\
\text { Beep = false } \\
\text { Most Recent Alarm } \\
\text { - Message Status = Acknowledged } \\
\text { - } \quad \text { Display Color = Yellow } \\
\text { - Text Color = Black } \\
\\
\text { Discrete Functional Test Workspace } \\
\text { Discrete - 2001 } \\
\text { Discrete lcon Blinking = false } \\
\text { - Display Color = YELLOW } \\
\text { B } \quad \text { Blink-off Color = (N/A - skip) } \\
\text { Alarm Aux Color = YELLOW }\end{array}$ & \\
\hline
\end{tabular}


HNF-3967, Rev. 4

\begin{tabular}{|c|c|c|c|}
\hline Step & Perform & Expected Result & Initial \\
\hline & & $\begin{array}{l}\text { Tank Icon Test-201 } \\
\text { - } \quad \text { Icon Blinking }=\text { false } \\
\text { - } \quad \text { Display Color }=\text { YELLOW } \\
\text { Blink-off Color }=\text { (N/A - skip) } \\
\text { Latest Alarm Message } \\
\text { - Display Color = Yellow } \\
\text { Continuous Functional Test Workspace } \\
\text { Continuous -2001 } \\
\text { - Cont. Icon Blinking = false } \\
\text { - Display Color = GREEN } \\
\text { - Blink-off Color }=\text { (N/A - skip) } \\
\text { - } \text { Alarm Aux Color = TRANSPARENT } \\
\text { Tank Icon Test-201 } \\
\text { - Icon Blinking }=\text { false } \\
\text { - Display Color = YELLOW } \\
\text { - Blink-off Color }=\text { (N/A - skip) } \\
\text { Latest Alarm Message } \\
\text { - Display Color = Yellow }\end{array}$ & \\
\hline 3. & $\begin{array}{l}\text { Enter } \underline{0} \text { in Dip-switch type-in box } \\
\text { on the Discrete Functional Test } \\
\text { Workspace. }\end{array}$ & $\begin{array}{l}\text { Beep } \\
\text { Beep = false } \\
\text { Most Recent Alarm } \\
\text { - Message Status = Alarm Disappears } \\
\text { Discrete Functional Test Workspace } \\
\text { Discrete - 2001 } \\
\text { - Discrete Icon Blinking = false } \\
\text { - Display Color }=\text { GREEN } \\
\text { Blink-off Color }=\text { (N/A - skip) } \\
\text { Alarm Aux Color = TRANSPARENT } \\
\text { Tank Icon Test-201 } \\
\text { - Icon Blinking = false } \\
\text { Display Color }=\text { GREEN } \\
\text { Blink-off Color = (N/A - skip) }\end{array}$ & \\
\hline
\end{tabular}


HNF-3967, Rev. 4

\begin{tabular}{|c|c|c|c|}
\hline Step & Perform & Expected Result & Initial \\
\hline & & $\begin{array}{l}\text { Latest Alarm Message } \\
-\quad \text { Display Color }=\text { YELLOW }\end{array}$ & \\
\hline & & $\begin{array}{l}\text { Continuous Functional Test Workspace } \\
\text { Continuous -2001 } \\
\text { - Cont. Icon Blinking = false } \\
\text { - } \quad \text { Display Color = GREEN } \\
\text { - } \quad \text { Blink-off Color = (N/A - skip) } \\
\text { - } \quad \text { Alarm Aux Color = TRANSPARENT } \\
\text { Tank Icon Test-201 } \\
\text { - Icon Blinking = false } \\
\text { - Display Color = GREEN } \\
\text { - Blink-off Color = (N/A - skip) } \\
\text { Latest Alarm Message } \\
\text { - Display Color = YELLOW } \\
\end{array}$ & \\
\hline 4. & $\begin{array}{l}\text { Enter a } 17 \text { in Milli-amp type-in } \\
\text { box on the Continuous }\end{array}$ & $\begin{array}{l}\text { Beep } \\
\text { Beep }=\text { true }\end{array}$ & \\
\hline & & $\begin{array}{l}\text { Most Recent Alarm } \\
\text { - Message Status = ALARM HIGH } \\
\text { - Display Color = RED } \\
\text { - Text Color = YELLOW }\end{array}$ & \\
\hline & & $\begin{array}{l}\text { Discrete Functional Test Workspace } \\
\text { Discrete }-2001 \\
\text { - Discrete Icon Blinking = false } \\
\text { - Display Color = GREEN } \\
\text { - Blink-off Color = (N/A - skip) } \\
\text { - Alarm Aux Color = TRANSPARENT } \\
\text { Tank Icon Test-201 } \\
\text { - Icon Blinking = true } \\
\text { - Display Color = RED } \\
\text { - Blink-off Color = GRAY } \\
\text { Latest Alarm Message }\end{array}$ & \\
\hline
\end{tabular}


HNF-3967, Rev. 4

\begin{tabular}{|c|c|c|c|}
\hline Step & Perform & Expected Result & Initial \\
\hline & & $\begin{array}{l}\text { - Display Color = YELLOW } \\
\text { Continuous Functional Test Workspace } \\
\text { Continuous -2001 } \\
\text { - Cont. Icon Blinking = true } \\
\text { - Display Color }=\text { RED } \\
\text { - Blink-off Color }=\text { GRAY } \\
\text { - } \quad \text { Alarm Aux Color = RED } \\
\text { Tank Icon Test-201 } \\
\text { - Icon Blinking = true } \\
\text { - Display Color = RED } \\
\text { - Blink-off Color = GRAY } \\
\text { Latest Alarm Message } \\
\text { - Display Color = RED }\end{array}$ & \\
\hline 5 . & $\begin{array}{l}\text { Enter } 1 \text { in Dip-switch type-in box } \\
\text { on the Discrete Functional Test } \\
\text { Workspace. }\end{array}$ & $\begin{array}{l}\text { Beep } \\
\text { Beep = true } \\
\text { Most Recent Alarm } \\
\text { - Message Status = CLOSING } \\
\text { - Display Color = YELLOW } \\
\text { - Text Color = RED } \\
\text { Discrete Functional Test Workspace } \\
\text { Discrete - 2001 } \\
\text { - Discrete Icon Blinking = true } \\
\text { - Display Color = YELLOW } \\
\text { Blink-off Color = GRAY } \\
\text { Alarm Aux Color = YELLOW } \\
\text { Tank Icon Test-201 } \\
\text { Icon Blinking = true } \\
\text { - Display Color = RED } \\
\text { Blink-off Color = GRAY } \\
\text { Latest Alarm Message }\end{array}$ & \\
\hline
\end{tabular}


HNF-3967, Rev. 4

\begin{tabular}{|c|c|c|c|}
\hline Step & Perform & Expected Result & Initial \\
\hline & & $\begin{array}{l}\text { - Display Color = YELLOW } \\
\text { Continuous Functional Test Workapace } \\
\text { Continuous -2001 } \\
\text { - Cont. Icon Blinking = true } \\
\text { - Display Color = RED } \\
\text { - Blink-off Color = GRAY } \\
\text { - Alarm Aux Color = RED } \\
\text { Tank Icon Test-201 } \\
\text { - Icon Blinking = true } \\
\text { - Display Color = RED } \\
\text { - Blink-off Color = GRAY } \\
\text { Latest Alarm Message } \\
\text { - Display Color = RED }\end{array}$ & \\
\hline 6. & $\begin{array}{l}\text { Enter a } 25 \text { in Milli-amp type-in } \\
\text { box on the Continuous } \\
\text { Functional Test Workspace }\end{array}$ & $\begin{array}{l}\text { Beep } \\
\text { Beep = true } \\
\text { Most Recent Alarm } \\
\text { - Message Status = Reading Out Of } \\
\text { Range } \\
\text { - Display Color = WHITE } \\
\text { - Text Color = BLACK } \\
\\
\text { Discrete Functional Test Workspace } \\
\text { Discrete - 2001 } \\
\text { Discrete Icon Blinking = true } \\
\text { Display Color = YELLOW } \\
\text { Blink-off Color = GRAY } \\
\text { - Alarm Aux Color = YELLOW } \\
\text { Tank Icon Test-201 } \\
\text { Icon Blinking = true } \\
\text { Display Color = YELLOW } \\
\text { - Blink-off Color = WHITE } \\
\text { Latest Alarm Message }\end{array}$ & \\
\hline
\end{tabular}


HNF-3967, Rev. 4

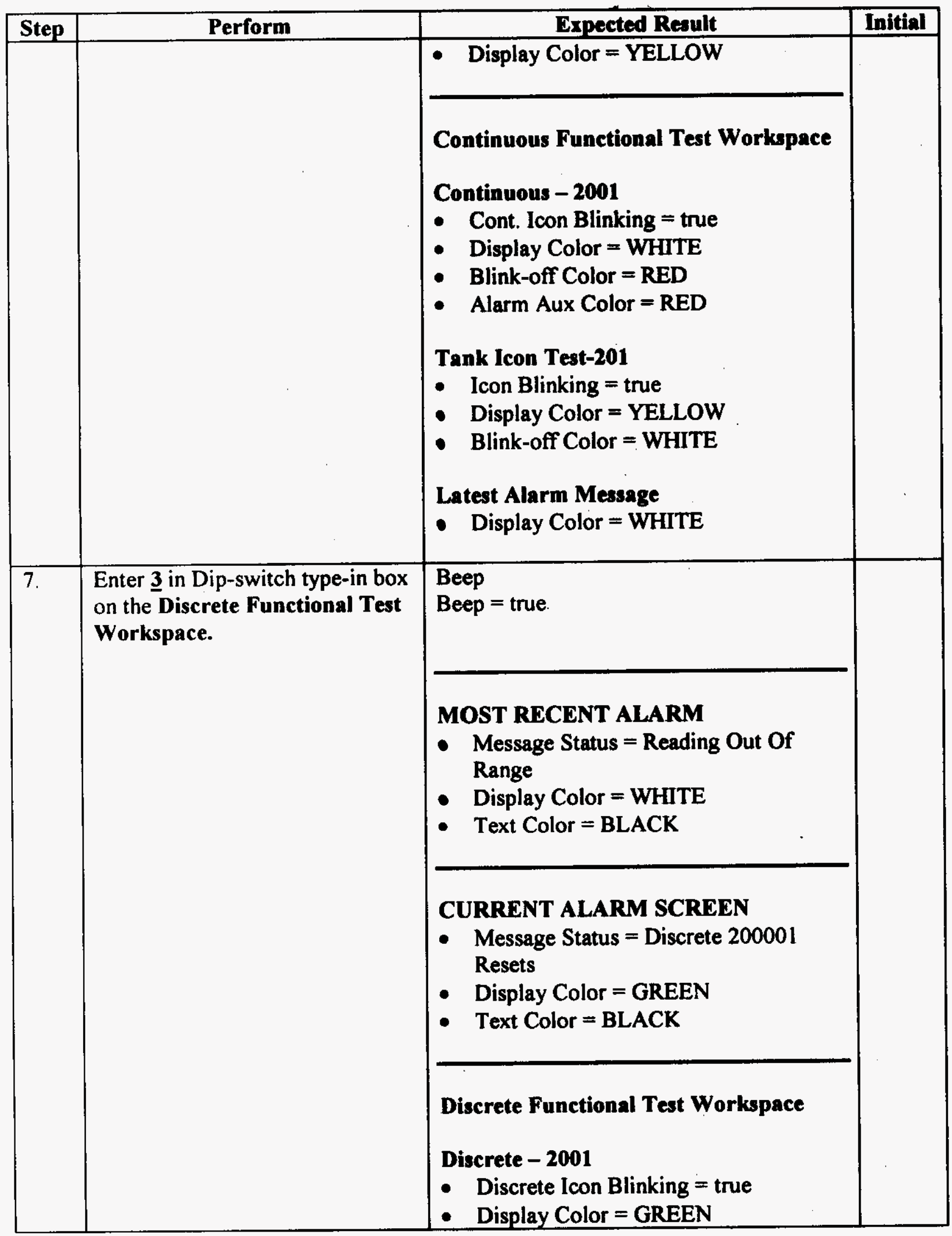


HNF-3967, Rev. 4

\begin{tabular}{|c|c|c|c|}
\hline Step & Perform & Expected Result & Initial \\
\hline & 5 & 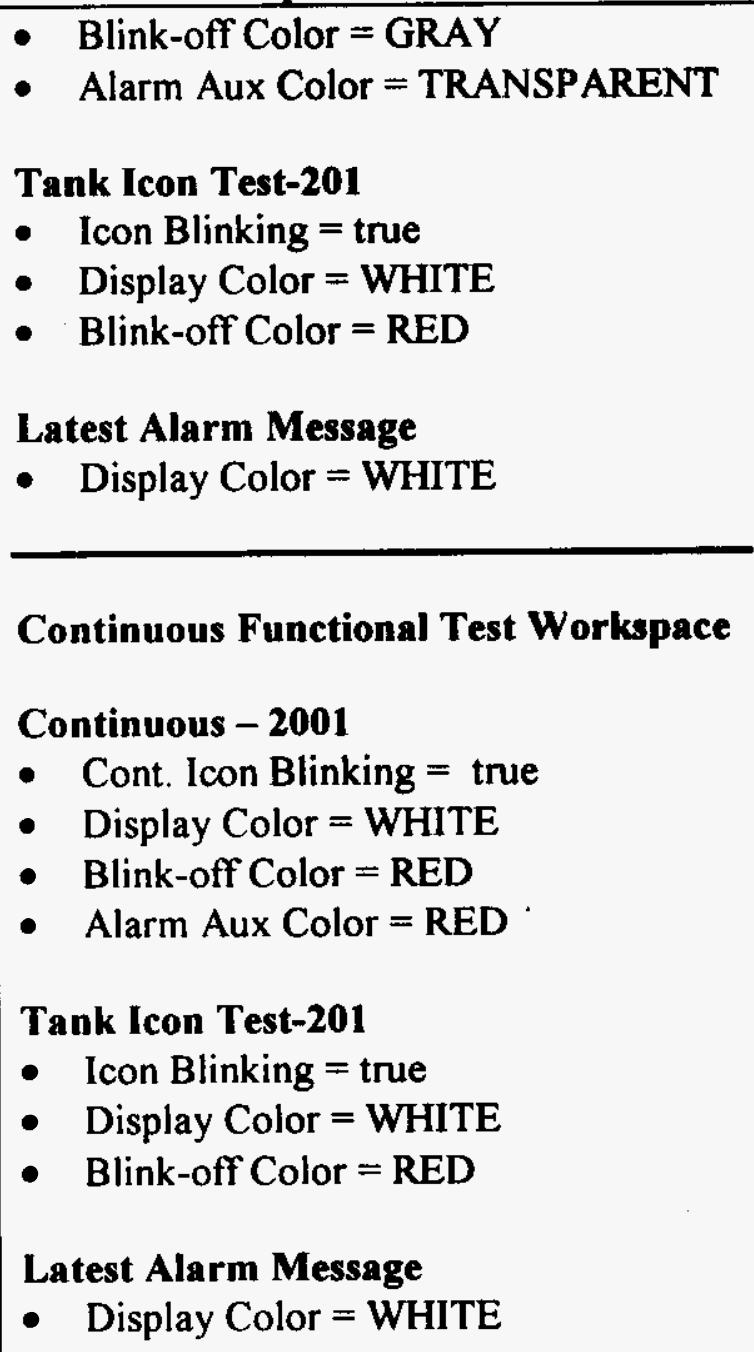 & \\
\hline 8. & $\begin{array}{l}\text { Acknowledge alarm messages } \\
\text { and hide the Point Processing } \\
\text { Functional Test workspaces. }\end{array}$ & $\begin{array}{l}\text { Verify the following: } \\
\text { beep is silenced } \\
\text { Point Processing Functional Test } \\
\text { workspaces are hidden. }\end{array}$ & \\
\hline
\end{tabular}

\subsection{LOGGING}

\subsubsection{Current}


The data files in this section are created upon system startup and then around midnight are closed and moved to the history directory and another file with the current date is created.

\subsubsection{Alarm Logging}

\begin{tabular}{|c|c|c|c|}
\hline Step & Perform & Expected Result & Initial \\
\hline 1. & $\begin{array}{l}\text { Examine the } \\
\text { almhst_YYYY_MM_DD_HHmm.dat. } \\
\text { Where } \\
\text { YYYY = the year } \\
\mathrm{MM}=\text { the month } \\
\mathrm{DD}=\text { the day } \\
\mathrm{HH}=\text { the hour } \\
\mathrm{mm}=\text { the minute } \\
\text { To examine the files it may be necessary } \\
\text { to stop } G 2^{\text {o. }} \text {. The directory is localed at } \\
\text { f: Backedlip } \mid T M A C S \text { DatalCurrent. }\end{array}$ & $\begin{array}{l}\text { Verify the following: } \\
\text { - High/low alarm conditions } \\
\text { and resets recorded } \\
\text { - Format match the } \\
\text { description given in the } \\
\text { LMSI External Letter, } \\
\text { RGG-SDl-99-001, TMACS } \\
\text { Data File Formats, Release } \\
\text { 11.0. }\end{array}$ & \\
\hline 2. & $\begin{array}{l}\text { Examine the } \\
\text { equip_fail_YYYY_MM_DD_HHmm.dat. } \\
\text { Where } \\
\text { YYYY = the year } \\
\mathrm{MM}=\text { the month } \\
\mathrm{DD}=\text { the day } \\
\mathrm{HH}=\text { the hour } \\
\mathrm{mm}=\text { the minute } \\
\\
\text { To examine the files it may be necessary } \\
\text { to stop G2 } 2^{\infty} \text {. The directory is located at } \\
\text { : } \mid \text { Backedlip } \mid \text { TMACSDatalCurrent. }\end{array}$ & $\begin{array}{l}\text { Verify the following } \\
\text { - Loss of communication } \\
\text { messages are recorded } \\
\text { - Format match the } \\
\text { description given in the } \\
\text { LMSI External Letter, } \\
\text { RGG-SDI-99-001, TMACS } \\
\text { Data File Formats, } \\
\text { Release 11.0. }\end{array}$ & \\
\hline
\end{tabular}




\subsubsection{Discrete Sensor Data Logging}

\begin{tabular}{|c|c|c|c|}
\hline Step & Perform & Expected Result & Initial \\
\hline 1. & $\begin{array}{l}\text { Examine the } \\
\text { discrete_sensor_history_YYYY_MMDD.ascii. } \\
\text { Where } \\
\text { YYYY - is the year created } \\
\text { MM - is the month created } \\
\text { DD - is the day created } \\
\text { To examine the file it may be necessary to stop } \\
\text { G2. The directory is located at } \\
f: \text { BackedIJp } \backslash \text { TMACSDatalCurrent. }\end{array}$ & $\begin{array}{l}\text { Verify the following: } \\
\text { - Reading messages are } \\
\text { being recorded properly. } \\
\text { Format match the } \\
\text { description given in the } \\
\text { LMSI External Letter, } \\
\text { RGG-SDI-99-001, } \\
\text { TMACS Data File } \\
\text { Formats, Release 11.0. }\end{array}$ & \\
\hline
\end{tabular}

\subsubsection{Continuous Sensor Data Logging}

Continuous sensor history is recorded in the continuous_sensor_history_YYYY_MMDD.ascii file where

YYYY - is the year that the file was created.

$\mathrm{MM}$ - is the month that the file was created.

DD - is the day that the file was created.

To examine the file it may be necessary to stop $G 2^{\infty}$. The directory is:

- $f: B a c k e d U p \backslash T M A C S D a t a l C u r r e n t$.

\begin{tabular}{|c|c|c|c|}
\hline Step & Perform & Expected Result & Initial \\
\hline 1. & $\begin{array}{l}\text { Examine the continuous_sensor_history } \\
\text { _YYYY_MMDD_ascii. } \\
\text { Where } \\
\text { YYYY - is the year created } \\
\text { MM - is the month created } \\
\text { DD - is the day created } \\
\text { To examine the file it may be necessary to stop } \\
\text { G2. The directory is located at } \\
\text { f: Backedl/p } 1 \text { TMACSDatalCurrent. }\end{array}$ & $\begin{array}{l}\text { Verify the following: } \\
\text { - Reading messages are } \\
\text { being recorded properly. } \\
\text { Format match the } \\
\text { description given in the } \\
\text { LMSI External Letter, } \\
\text { RGG-SDI-99-001, } \\
\text { TMACS Dala File } \\
\text { Formats, Release 11.0. }\end{array}$ & \\
\hline
\end{tabular}

\subsubsection{Nightly File Creations}

Eight files are created nightly by TMACS (rdbms files are created around 4:00 AM, all others created around 12:00 AM) 
HNF-3967, Rev. 4

\begin{tabular}{|c|c|c|c|}
\hline Step & Perform & Verify & Initial \\
\hline 1. & $\begin{array}{l}\text { Let the system run over } \\
\text { night. (Note: Test } \\
\text { Director may opt to change } \\
\text { the system clock to } \\
\text { simulate overnight. This } \\
\text { requires time periods } \\
\text { around midnight and } \\
4 \text { AM) } \\
\text { Check the location } \\
\text { f: } \text { BackedUp\TMACSDatal } \\
\text { History to determine if the } \\
\text { files have been created. }\end{array}$ & $\begin{array}{l}\text { Verify that the following flat files are } \\
\text { created: } \\
\text { - almhst_yyyy_mmdd_mmss.dat } \\
\text { - continuous_sensor_history } \\
\text { yyyy_mmdd.ascii } \\
\text { - discrete_sensor_history_yyyy_mmd } \\
\text { d.ascii } \\
\text { equip_fail_yyyy_mmdd_mmss.dat } \\
\text { - perf_data_yyyy_mmdd.dat } \\
\text { dst_data_yyyy_mmdd_mmss.rdbms } \\
\text { - sst_data_yyyy_mmdd_mmss.rdbms } \\
\text { where: } \\
\text { yyyy = the year } \\
\text { mm = the month } \\
\text { dd = the day } \\
\text { hh = the hour } \\
\text { mm = the minute } \\
\text { Verify that the fields in the files match } \\
\text { the description given in the LMSI } \\
\text { External Letter, RGG-SDI-99-001, } \\
\text { IMACSDataFile Formats, Release } \\
11.0 \text {. }\end{array}$ & \\
\hline
\end{tabular}

\subsection{PERFORMACE}

\subsubsection{CPU Use Vs Number of Continuous Points/Sec Performance Test}

\begin{tabular}{|l|l|l|l|}
\hline Step & \multicolumn{1}{|c|}{ Perform } & \multicolumn{1}{|c|}{ Expected Result } & Initial \\
\hline 1. & $\begin{array}{l}\text { On the Point Processing } \\
\text { Performance Test workspace click } \\
\text { on the "CPU Use Versus Number } \\
\text { of Continuous Points/Sec" } \\
\text { button. }\end{array}$ & $\begin{array}{l}\text { Verify the correct workspace is } \\
\text { shown. }\end{array}$ & \\
\hline 2. & $\begin{array}{l}\text { Click on the "Start Performance } \\
\text { Test" button. }\end{array}$ & $\begin{array}{l}\text { Verify the test runs and that the } \\
\text { \%CPU/pt/sec values are less than } \\
\text { After the Test Running box turns } \\
\text { to FALSE examine the results. } \\
\text { (The test will take about } \\
\text { points/second. }\end{array}$ & \begin{tabular}{l} 
minutes to run $)$ \\
\hline
\end{tabular}
\end{tabular}




\begin{tabular}{|l|l|l|l|}
\hline Step & \multicolumn{1}{|c|}{ Perform } & \multicolumn{1}{|c|}{ Expected Result } & Initial \\
\hline 3. & Click on the "Print" button. & $\begin{array}{l}\text { Verify that the workspace prints. } \\
\text { Attach the printout to this test } \\
\text { procedure. }\end{array}$ & \\
\hline 4. & $\begin{array}{l}\text { Hide the Performance Test } \\
\text { workspace(s) }\end{array}$ & $\begin{array}{l}\text { Verify the workspace(s) is } \\
\text { hidden. }\end{array}$ & \\
\hline
\end{tabular}

\subsubsection{CPU Use Vs Number of Discrete Points/Sec Performance Test}

\begin{tabular}{|c|c|c|c|}
\hline Step & Perform & Expected Result & Initial \\
\hline 1. & $\begin{array}{l}\text { On the Point Processing } \\
\text { Performance Test workspace click } \\
\text { on the "CPU Use Versus Number } \\
\text { of Discrete Points/Sec" button. }\end{array}$ & $\begin{array}{l}\text { Verify the correct Performance } \\
\text { Test workspace is shown. }\end{array}$ & \\
\hline 2. & $\begin{array}{l}\text { Click on the "Start Performance } \\
\text { Test" button. } \\
\text { After the Test Running box turns } \\
\text { to FALSE examine the results. } \\
\text { (The test will take about } \\
20 \text { minutes to run) }\end{array}$ & $\begin{array}{l}\text { Verify that the test runs and that } \\
\text { the } \% \mathrm{CPU} / \mathrm{pt} / \mathrm{sec} \text { values are less } \\
\text { than } 0.82 \text { for all values of } \\
\text { points/second. }\end{array}$ & \\
\hline 3. & Click on the "Print" button. & $\begin{array}{l}\text { Verify that the workspace prints. } \\
\text { Attach the printout to this test } \\
\text { procedure. }\end{array}$ & \\
\hline 4. & $\begin{array}{l}\text { Hide the Performance Test } \\
\text { workspace(s) }\end{array}$ & $\begin{array}{l}\text { Verify the workspace(s) is } \\
\text { hidden. }\end{array}$ & \\
\hline
\end{tabular}

6.8.3 CPU Use Vs Pt-Processing Function for Continuous Points Performance Test

\begin{tabular}{|l|l|l|l|}
\hline Step & \multicolumn{1}{|c|}{ Perform } & \multicolumn{1}{|c|}{ Expected Result } & Initial \\
\hline 1. & $\begin{array}{l}\text { On the Point Processing } \\
\text { Performance Test workspace } \\
\text { click on the Click on the } \\
\text { "CPU Use Versus Point- } \\
\text { Processing Function for } \\
\text { Continuous Points" button. }\end{array}$ & $\begin{array}{l}\text { Verify the correct Performance Test } \\
\text { workspace is shown. }\end{array}$ & \\
\hline
\end{tabular}




\begin{tabular}{|c|c|c|c|}
\hline Step & Perform & Expected Result & Initial \\
\hline 2. & $\begin{array}{l}\text { Click on the "Start } \\
\text { Performance Test" button. } \\
\text { After the Test Running box } \\
\text { turns to FALSE examine the } \\
\text { results. (The test will take } \\
\text { about } 20 \text { minutes to run) }\end{array}$ & $\begin{array}{l}\text { Verify that the test runs and that for } \\
\text { each Point Processing Breakdown } \\
\text { that the following criteria are met. } \\
\text { Update Pt. the \%CPU per points } / \mathrm{sec}< \\
0.23 \\
\text { Delta Check the \%CPU per points } / \mathrm{sec} \\
<0.15 \\
\text { Alarm Check the \%CPU per } \\
\text { points } / \mathrm{sec}<0.07 \\
\text { ROC Check the \%CPU per points } / \mathrm{sec} \\
<0.12 \\
\text { Log to Disk the \%CPU per points } / \mathrm{sec} \\
<0.57\end{array}$ & 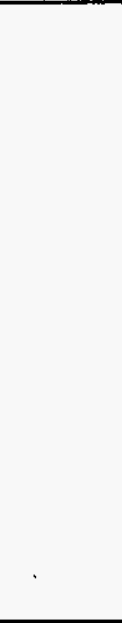 \\
\hline 3. & Click on the "Print" button. & $\begin{array}{l}\text { Verify that the workspace prints. } \\
\text { Attach the printout to this test } \\
\text { procedure. }\end{array}$ & \\
\hline 4. & $\begin{array}{l}\text { Hide the Performance Test } \\
\text { workspace }\end{array}$ & Verify the workspace is hidden. & \\
\hline
\end{tabular}

\subsubsection{CPU Use Vs Point-Processing Function for Discrete Points Performance Test}

\begin{tabular}{|c|c|c|c|}
\hline Step & Perform & Expected Result & Initial \\
\hline 1. & $\begin{array}{l}\text { On the Point Processing } \\
\text { Performance Test } \\
\text { workspace click on the } \\
\text { Click on the "CPU Use } \\
\text { Versus Point-Processing } \\
\text { Function for Discrete } \\
\text { Points" button. }\end{array}$ & $\begin{array}{l}\text { Verify the correct Performance Test } \\
\text { workspace is shown. }\end{array}$ & \\
\hline 2. & $\begin{array}{l}\text { Click on the "Start } \\
\text { Performance Test" button. } \\
\text { After the Test Running } \\
\text { box turns to FALSE } \\
\text { examine the results. (The } \\
\text { test will take about } \\
20 \text { minutes to run) }\end{array}$ & $\begin{array}{l}\text { Verify that the test runs and that for each } \\
\text { Point Processing Breakdown that the } \\
\text { following criteria are met. } \\
\text { for Update Pt. the \%CPU per points } / \mathrm{sec} \\
<0.28 \\
\text { for Alarm Check the \%CPU per } \\
\text { points } / \mathrm{sec}<0.07 \\
\text { for Log to Disk the } \% \mathrm{CPU} \text { per points } / \mathrm{sec} \\
<0.57\end{array}$ & \\
\hline 3. & $\begin{array}{l}\text { Click on the "Print" } \\
\text { button. }\end{array}$ & $\begin{array}{l}\text { Verify that the workspace prints. } \\
\text { Attach the printout to this test procedure. }\end{array}$ & \\
\hline 4. & $\begin{array}{l}\text { Hide the Performance } \\
\text { Test workspace }\end{array}$ & Verify the workspace is hidden. & \\
\hline
\end{tabular}


HNF-3967, Rev. 4

\subsection{SERVICE REQUESTS}

\subsubsection{SR 103 - Make the GSI Data Service Priority Lower Than The Processing Rule Priority}

\begin{tabular}{|l|l|l|l|}
\hline Step & \multicolumn{1}{|c|}{ Perform } & \multicolumn{1}{c|}{ Expected Result } & Initial \\
\hline 1. & $\begin{array}{l}\text { Display the priority for the } \\
\text { GSI Data Service } \\
\begin{array}{l}\text { Display the priority for the } \\
\text { Processing Rule }\end{array}\end{array}$ & $\begin{array}{l}\text { Verify the GSI Data Service priority is } \\
\text { lower than the Processing Rule priority }\end{array}$ & \\
\hline
\end{tabular}

\subsubsection{SR 132 - Add Individual Trend Graphs For Discrete Sensors}

\begin{tabular}{|c|c|c|c|}
\hline Step. & Perform & Expected Result & Initial \\
\hline 1. & $\begin{array}{l}\text { Select a Discrete } \\
\text { Sensor at random } \\
\text { (Note: Only } \\
\text { discrete sensor } \\
\text { displayed to the } \\
\text { TMACS operator } \\
\text { can be displayed by } \\
\text { the operator.) } \\
\text { Click on the portion } \\
\text { of any sensor icon } \\
\text { that looks like a } \\
\text { little chart. }\end{array}$ & $\begin{array}{l}\text { Verify that a Sensor Trend workspace for the } \\
\text { sensor chosen and contains the following. } \\
\text { - Chart } \\
\text { - HIDE WINDOW }(X) \text { button } \\
\text { - DETAIL (D) button. } \\
\text { - PRINT (P) button }\end{array}$ & \\
\hline 2. & Examine the Chart. & $\begin{array}{l}\text { Verify the following: } \\
\text { The values line color is black.. } \\
\text { The time scale of the horizontal time axis is } 7 \\
\text { days and that some dates are shown. }\end{array}$ & \\
\hline 3. & $\begin{array}{l}\text { Click on the Print } \\
\text { button. }\end{array}$ & Verify the Sensor Trend workspace is printed. & \\
\hline 4. & $\begin{array}{l}\text { Click on the HIDE } \\
\text { WINDOW button. }\end{array}$ & Verify that the workspace is hidden. & \\
\hline
\end{tabular}




\begin{tabular}{|c|c|c|c|c|}
\hline Step & Perform & \multicolumn{2}{|c|}{ Expected Result } & Initial \\
\hline \multirow[t]{2}{*}{5 . } & \multirow[t]{2}{*}{$\begin{array}{l}\text { Click on the Details } \\
\text { (D) button. }\end{array}$} & \multicolumn{2}{|c|}{$\begin{array}{l}\text { Verify the Sensor Details workspace for the } \\
\text { chosen sensor is displayed with the following } \\
\text { information: } \\
\text { - Hide }(X) \text { button } \\
\text { - Print }(P) \text { button } \\
\text { - Update }(U) \text { button } \\
\text { And the following sensor information groups. }\end{array}$} & \\
\hline & & $\begin{array}{l}\text { Current Reading } \\
\text { Last Good Reading } \\
\text { Quality Status } \\
\text { Upper Instrument } \\
\text { Limit } \\
\text { Lower Instrument } \\
\text { Limit } \\
\text { Point Processing } \\
\text { ROC Processing } \\
\text { Station Status } \\
\text { Polling Freq. Index } \\
\text { Displacer Postion } \\
\text { Level Status } \\
\text { Alarm Status } \\
\text { Validity Interval } \\
\text { Expiration Time } \\
\text { Formula Expression } \\
\text { Formula Parameter }\end{array}$ & $\begin{array}{l}\text { Last Update Method } \\
\text { Test Processing } \\
\text { Alarm Processing } \\
\text { Logging } \\
\text { Raw Value } \\
\text { Polling Freq. Sec. } \\
\text { Waste Level } \\
\text { Level status mode } \\
\text { Alarm status mode }\end{array}$ & \\
\hline
\end{tabular}

6.9.3 SR 166 - Modify TMACS To Display the K-Basin Communications Alarm As Red

\begin{tabular}{|l|l|l|l|}
\hline Step & \multicolumn{1}{|c|}{ Perform } & \multicolumn{1}{c|}{ Expected Result } & Initial \\
\hline 1. & $\begin{array}{l}\text { Generate a K-Basin } \\
\text { Communications failure. }\end{array}$ & $\begin{array}{l}\text { Verify the K-Basin Communications } \\
\text { Alarm displayed on the Monitored } \\
\text { Systems - K Basin workspace is shown } \\
\text { in red. }\end{array}$ & \\
\hline
\end{tabular}

\subsubsection{SR 403 - Modify TMACS To Generate A Sensor Limits List}

\begin{tabular}{|l|l|l|l|}
\hline Step & \multicolumn{1}{|c|}{ Perform } & \multicolumn{1}{c|}{ Expected Result } & Initial \\
\hline 1. & $\begin{array}{l}\text { Log onto TMACS in the } \\
\text { administrator mode. } \\
\text { Generate a Sensor Limits }\end{array}$ & $\begin{array}{l}\text { Verify the report shows the limits for } \\
\text { the define sensor. }\end{array}$ & \\
\hline
\end{tabular}


HNF-3967, Rev. 4

\begin{tabular}{|c|l|c|c|}
\hline Step & \multicolumn{1}{|c|}{ Perform } & Expected Result & Initial \\
\hline & Report. & & \\
\hline
\end{tabular}

6.9.5 SR 434 - Modify TMACS To Read Pressure Sensors through ENRAF CIU device.

This service request is completed upon successful completion of section 6.5.2.2 "Conversion of Enraf CIU Pressure Sensor Output to Engineering Units"

\subsubsection{SR 752 - Modify ENRAF Driver To Properly Handle “!” Commands}

\begin{tabular}{|l|l|l|l|}
\hline Step & \multicolumn{1}{|c|}{ Perform } & \multicolumn{1}{c|}{ Expected Result } & Initial \\
\hline 1. & $\begin{array}{l}\text { Using the ENRAF } \\
\text { emulator generate several } \\
\text { of the "! " Commands }\end{array}$ & $\begin{array}{l}\text { Verify that a white message is generated } \\
\text { for each of the "!" command emulated } \\
\text { and that the message identifies the } \\
\text { appropriate command. }\end{array}$ & \\
\hline
\end{tabular}

6.9.7 SR 856 - Devise Method To Notify The Operator When An ENRAF Level Gauge Has A Status Other Than "_.“

This service request is completed upon successful completion of section 6.4.4 "ENRAF NonOperating Mode Report"

6.9.8 857 - Correct Unknown Sensor Report To Display Only Sensors Associated With Tanks.

\begin{tabular}{|l|l|l|c|}
\hline Step & \multicolumn{1}{|c|}{ Perform } & \multicolumn{1}{c|}{ Expected Result } & Initial \\
\hline 1. & $\begin{array}{l}\text { Display the Unknown } \\
\text { Sensor Report }\end{array}$ & $\begin{array}{l}\text { Verify the only sensors associated with } \\
\text { tanks are displayed. }\end{array}$ & \\
\hline
\end{tabular}

6.9.9 SR 858 - Modify The Suspect Sensor IO Station Report To Not Display Stations With A Polling Frequency of Zero

\begin{tabular}{|l|l|l|l|}
\hline Step & \multicolumn{1}{|c|}{ Perform } & \multicolumn{1}{c|}{ Expected Result } & Initial \\
\hline 2. & $\begin{array}{l}\text { Select 1 or 2 IO Stations } \\
\text { at random. }\end{array}$ & $\begin{array}{l}\text { Verify the Stations with the polling } \\
\text { frequency set to 0 are not displayed. } \\
\text { Set the Polling Frequency } \\
\text { for the Stations to be 0. }\end{array}$ & \\
$\begin{array}{l}\text { Display the Suspect } \\
\text { Sensor IO Station Report. }\end{array}$ & & \\
\hline
\end{tabular}

6.9.10 SR 860 - Correct Problem of Old Print Workspace Being Displayed For Multiple Sensor Trends 


\begin{tabular}{|l|l|l|l|}
\hline Step & \multicolumn{1}{|c|}{ Perform } & \multicolumn{1}{|c|}{ Expected Result } & Initial \\
\hline 1. & $\begin{array}{l}\text { Run and inspect command } \\
\text { that displays the buttons } \\
\text { that invoke the Old Print } \\
\text { Workspace. }\end{array}$ & Verify that there is none listed. & \\
\hline 2. & $\begin{array}{l}\text { Select 1 or 2 Multiple } \\
\text { Sensor Trends at random. } \\
\text { Select the Print button. }\end{array}$ & $\begin{array}{l}\text { Verify the Old Print Workspace is not } \\
\text { displayed and that the workspace is } \\
\text { printed properly. }\end{array}$ & \\
\hline
\end{tabular}

6.9.11 SR 862 - Correct Problem Where Sensor With Alarm Processing Turned Off Does Not Restore To Correct Color When Communications Are Re-Established

\begin{tabular}{|c|c|c|c|}
\hline Step & Perform & Expected Result & Initial \\
\hline 1. & $\begin{array}{l}\text { Select an active sensor at } \\
\text { random. } \\
\text { Disable alarm processing } \\
\text { for the chosen sensor. } \\
\text { Using the emulator } \\
\text { transmit a value that is in } \\
\text { the alarm range for the } \\
\text { chosen sensor }\end{array}$ & $\begin{array}{l}\text { Verify an Alarm Message is not } \\
\text { generated. }\end{array}$ & \\
\hline 2. & $\begin{array}{l}\text { Using the emulator } \\
\text { transmit a value that is out } \\
\text { of instrument range for the } \\
\text { chosen sensor. }\end{array}$ & $\begin{array}{l}\text { Verify a white alarm message is } \\
\text { generated for the chosen sensor and that } \\
\text { the sensor color turns to white. }\end{array}$ & \\
\hline 3. & $\begin{array}{l}\text { Using the emulator } \\
\text { transmit a value that is in } \\
\text { the normal operating range } \\
\text { for the chosen sensor. }\end{array}$ & $\begin{array}{l}\text { Verify the chosen sensor color turns to } \\
\text { green. }\end{array}$ & \\
\hline
\end{tabular}

6.9.12 SR 865 - Set Polling Frequency Of Double Shell Tanks To 10 Minutes Or Less

\begin{tabular}{|l|l|l|l|}
\hline Step & \multicolumn{1}{|c|}{ Perform } & \multicolumn{1}{c|}{ Expected Result } & Initial \\
\hline 1. & $\begin{array}{l}\text { Run an inspect command } \\
\text { that displays the Double } \\
\text { Shell Tanks with a polling } \\
\text { frequency of more than 10 } \\
\text { minutes. }\end{array}$ & Verify that there is none displayed. & \\
\hline
\end{tabular}




\subsubsection{SR 867 - Add Ability To Place A Sensor Into Test Mode}

This service request is completed upon successful completion of section 6.3.1.2 "Operation of Sensor Details"

\subsubsection{SR 869 - Configure Enraf Of Tanks BY102 and S110}

\begin{tabular}{|c|c|c|c|}
\hline Step & Perform & Expected Result & Initial \\
\hline 1. & $\begin{array}{l}\text { Display Tank BY-102 } \\
\text { workspace. }\end{array}$ & $\begin{array}{l}\text { Verify the ENRAF for this tank is } \\
\text { displayed. }\end{array}$ & \\
\hline 2. & $\begin{array}{l}\text { Display the sensor details } \\
\text { for the ENRAF sensor }\end{array}$ & $\begin{array}{l}\text { Verify the following: } \\
\text { - data source is from an ENRAF CIU } \\
\text { - sensor tag name is BY102-LI-R005- } \\
01\end{array}$ & \\
\hline 3. & $\begin{array}{l}\text { Repeat steps } 1 \text { and } 2 \text { for } \\
\text { Tank S-110 }\end{array}$ & $\begin{array}{l}\text { Verify the following: } \\
\text { - data source is from an ENRAF CIU } \\
\text { - sensor tag name is S110-LI-R003-01 }\end{array}$ & \\
\hline
\end{tabular}

6.9.15 SR 871 - Change Gauge Addresses for ENRAF Level Devices in Tanks AP105AP108

\begin{tabular}{|l|l|l|l|}
\hline Step & \multicolumn{1}{|c|}{ Perform } & \multicolumn{1}{|c|}{ Expected Result } & Initial \\
\hline 1. & $\begin{array}{l}\text { Display the sensor details } \\
\text { for the ENRAF level } \\
\text { device in tank AP105 }\end{array}$ & $\begin{array}{l}\text { Verify the sensor is configured for gauge } \\
\text { 31. Note the gauge address is the last } \\
\text { digit of the Formula Parameter) }\end{array}$ & \\
\hline 2. & $\begin{array}{l}\text { Display the sensor details } \\
\text { for the ENRAF level } \\
\text { device in tank AP106 }\end{array}$ & $\begin{array}{l}\text { Verify the sensor is configured for gauge } \\
\text { 32. (Note the gauge address is the last } \\
\text { digit of the Formula Parameter) }\end{array}$ & \\
\hline 3. & $\begin{array}{l}\text { Display the sensor details } \\
\text { for the ENRAF level } \\
\text { device in tank AP107 }\end{array}$ & $\begin{array}{l}\text { Verify the sensor is configured for gauge } \\
\text { 33. (Note the gauge address is the last } \\
\text { digit of the Formula Parameter) }\end{array}$ & \\
\hline 4. & $\begin{array}{l}\text { Display the sensor details } \\
\text { for the ENRAF level } \\
\text { device in tank AP108 }\end{array}$ & $\begin{array}{l}\text { Verify the sensor is configured for gauge } \\
\text { 34. (Note the gauge address is the last } \\
\text { digit of the Formula Parameter) }\end{array}$ & \\
\hline
\end{tabular}

\subsubsection{SR 873 - Create Report That Displays Active Sensors With Alarm Processing Disabled}

This service request is completed upon successful completion of section 6.4.5 "Sensor Disable Alarm Report". 


\subsection{TMACS SHUTDOWN}

\subsubsection{Telewindows ${ }^{\circledR}$ Session}

\begin{tabular}{|l|l|l|c|}
\hline Step & \multicolumn{1}{|c|}{ Action } & \multicolumn{1}{c|}{ Verify } & Initial \\
\hline 1. & $\begin{array}{l}\text { On the TMACS screen, type } \\
\text { Control-Y. }\end{array}$ & $\begin{array}{l}\text { Verify that the user mode selection } \\
\text { workspace appears on the screen. }\end{array}$ & \\
\hline 2. & $\begin{array}{l}\text { Edit the 'G2 } 2^{\Phi} \text { user mode' to be } \\
\text { "shutdown" and click on the } \\
\text { END. }\end{array}$ & $\begin{array}{l}\text { Verify that a warning message } \\
\text { appears indicating that this function } \\
\text { is not available. } \\
\text { Verify the 'G2 } \\
\text { reverted back to "t2-user". }\end{array}$ & \\
\hline
\end{tabular}

\subsubsection{Central Console}

\begin{tabular}{|c|c|c|c|}
\hline Step & Action & Verify & Initial \\
\hline 1. & On the TMACS screen, type Control-Y. & $\begin{array}{l}\text { Verify that the user mode } \\
\text { selection workspace } \\
\text { appears on the screen. }\end{array}$ & \\
\hline 2. & $\begin{array}{l}\text { Edit the 'G2 user mode' to be } \\
\text { "shutdown" and click on the END. }\end{array}$ & $\begin{array}{l}\text { Verify that } G 2^{\infty} \\
\text { terminates. }\end{array}$ & \\
\hline 3. & $\begin{array}{l}\text { As part of the shutdown process } \\
\text { TMACS creates the following files in } \\
\text { the directory } \\
\text { F:IBackedUpITMACSIDatalCurrent: } \\
\text { - Continuous_Shutdown_History_ } \\
\text { YYYY_MMDD.ascii. } \\
\text { - Discrete_Shutdown_History_ } \\
\text { YYYY_MMDD.ascii. } \\
\text { Where: } \\
\text { YYYY - is the year that the file was } \\
\text { created. } \\
\text { MM - is the month that the file was } \\
\text { created. } \\
\text { DD - is the day that the file was created. }\end{array}$ & $\begin{array}{l}\text { Verify that the files were } \\
\text { created and the format } \\
\text { match the description } \\
\text { given in the LMSI } \\
\text { External Letter, } \\
\text { RGG-SDI-99-001, } \\
\text { TMACS Data File } \\
\text { Formats, Release II.O. }\end{array}$ & \\
\hline
\end{tabular}


HNF-3967, Rev. 4

\section{EXCEPTION SHEETS}

The following page is an example of the form used to describe exceptions found during the running of this Acceptance Test Procedure. If exceptions are found, copies of this sheet should be completed and included in the Acceptance Test Report. 
HNF-3967, Rev. 4

\section{Acceptance Test Procedure Exception Record}

\begin{tabular}{|l|l|l|}
\hline Exception No. & Step No. & Date \\
\hline Originator/Organization & & \\
\hline Description: & & \\
& & \\
& & \\
& & \\
\hline Resolution: & & \\
& & \\
\hline Test Director & & \\
\hline QA & & \\
\hline ESH & & \\
\hline & & \\
\hline
\end{tabular}


HNF-3967, Rev. 4

\section{PARTICIPATION RECORD SHEET}

The following page is the form used to record the participants involved in the running of this Acceptance Test Procedure. This sheet should be completed and included in the Acceptance Test Report. 
HNF-3967, Rev. 4

\section{Acceptance Test Procedure \\ Participation Record}

TEST DIRECTOR

TEST PERFORMANCE GROUP

TEST WITNESS 
HNF-3967, Rev. 4

\section{ACCEPTANCE RECORD SHEET}

The following page is the form used record the participants involved in the running of this Acceptance Test Procedure. This sheet should be completed and included in the Acceptance Test Report. 
HNF-3967, Rev. 4

\section{Acceptance Test Procedure \\ Acceptance Record}

\section{CERTIFICATION OF SATISFACTORY EXECUTION}

All of the test cases for this test procedure have been tested and all exceptions for this test procedure have been resolved.

Test Director

Cognizant Engineer

Quality Assurance

Safety

Envirommental llealth 